\title{
The composition, geography, biology and assembly of the coastal flora of the Cape Floristic Region
}

\author{
B Adriaan Grobler ${ }^{\text {Corresp., }}{ }^{1}$, Richard M Cowling ${ }^{1}$ \\ ${ }^{1}$ African Centre for Coastal Palaeoscience, Nelson Mandela University, Gqeberha, Eastern Cape Province, South Africa \\ Corresponding Author: B Adriaan Grobler \\ Email address: adriaan.grobler85@gmail.com
}

The Cape Floristic Region (CFR) is globally recognized as a hotspot of plant diversity and endemism. Much of this diversity stems from radiations associated with infertile, acid sands derived from sandstones of the geologically ancient Cape Fold Belt. These ancient montane floras acted as the source for most subsequent radiations on the Cape lowlands during the Oligocene (on silcretes) and Mio-Pliocene (on shales). The geomorphic evolution of the CFR during the Plio-Pleistocene led to the first large-scale occurrence of calcareous substrata (coastal dunes and calcarenites) along the Cape coast, providing novel habitats for plant colonization and ensuing evolution of the Cape coastal flora - the most recent diversification event in the Cape. Few studies have investigated the CFR's dune and calcarenite floras, and fewer still have done so in an evolutionary context. Here, we present a unified flora of these coastal calcareous habitats of the CFR and analyze the taxonomic, biological and geographical traits of its component species to gain insights into its assembly. The Cape coastal flora, comprising 1,365 species, is taxonomically dominated by the Asteraceae, Fabaceae and Iridaceae, with Erica, Aspalathus and Agathosma being the most speciose genera. In terms of growth-form mix, there is a roughly equal split between herbaceous and woody species, the former dominated by geophytes and forbs, the latter by dwarf and low shrubs. Species associated with the Fynbos biome constitute the bulk of the flora, while the Thicket and Wetland biomes also house a substantial number of species. The Cape coastal flora is a distinctly southern African assemblage, with $61 \%$ of species belonging to southern African lineages (including $35 \%$ of species with Cape affinity) and $59 \%$ being endemic to the CFR. Unique among floras from the Cape and coastal Mediterranean-climate regions is the relatively high proportion of species associated with tropical lineages, several of which are restricted to calcareous substrata of the CFR. The endemic, calcicolous component of the flora, constituting $40 \%$ of species, represents $6 \%$ of the Cape's regional plant diversity - high tallies compared to other biodiversity hotspots. Most coastal-flora endemics emerged during the Plio-Pleistocene as a product of ecological speciation upon the colonization of Peer] reviewing PDF | (2021:05:60924:1:1:NEW 7 Jul 2021) 
calcareous substrata, with the calcifugous fynbos floras of montane acid substrata being the most significant source of this diversification, especially on the typically shallow soils of calcarenite landscapes. On the other hand, renosterveld floras, associated with edaphically benign soils that are widespread on the CFR lowlands, have not been a major source of lineages to the coastal flora. Our findings suggest that, over and above the strong $\mathrm{pH}$ gradient that exists on calcareous substrata, soil depth and texture may act as important edaphic filters to incorporating lineages from floras on juxtaposed substrata in the CFR. 
1 The composition, geography, biology and assembly of the 2 coastal flora of the Cape Floristic Region

3

4 B. Adriaan Grobler ${ }^{1}$ and Richard M. Cowling ${ }^{1}$

5

$6{ }^{1}$ African Centre for Coastal Palaeoscience, Nelson Mandela University, Gqeberha, Eastern

7 Cape, South Africa

8

9 Corresponding author:

10 B. Adriaan Grobler ${ }^{1}$

11

12 Email address: adriaan.grobler85@gmail.com 


\section{Abstract}

The Cape Floristic Region (CFR) is globally recognized as a hotspot of plant diversity and endemism. Much of this diversity stems from radiations associated with infertile, acid sands derived from sandstones of the geologically ancient Cape Fold Belt. These ancient montane floras acted as the source for most subsequent radiations on the Cape lowlands during the Oligocene (on silcretes) and Mio-Pliocene (on shales). The geomorphic evolution of the CFR during the Plio-Pleistocene led to the first large-scale occurrence of calcareous substrata (coastal dunes and calcarenites) along the Cape coast, providing novel habitats for plant colonization and ensuing evolution of the Cape coastal flora - the most recent diversification event in the Cape. Few studies have investigated the CFR's dune and calcarenite floras, and fewer still have done so in an evolutionary context. Here, we present a unified flora of these coastal calcareous habitats of the CFR and analyze the taxonomic, biological and geographical traits of its component species to gain insights into its assembly. The Cape coastal flora, comprising 1,365 species, is taxonomically dominated by the Asteraceae, Fabaceae and Iridaceae, with Erica, Aspalathus and Agathosma being the most speciose genera. In terms of growth-form mix, there is a roughly equal split between herbaceous and woody species, the former dominated by geophytes and forbs, the latter by dwarf and low shrubs. Species associated with the Fynbos biome constitute the bulk of the flora, while the Thicket and Wetland biomes also house a substantial number of species. The Cape coastal flora is a distinctly southern African assemblage, with $61 \%$ of species belonging to southern African lineages (including 35\% of species with Cape affinity) and 59\% being endemic to the CFR. Unique among floras from the Cape and coastal Mediterraneanclimate regions is the relatively high proportion of species associated with tropical lineages, several of which are restricted to calcareous substrata of the CFR. The endemic, calcicolous component of the flora, constituting $40 \%$ of species, represents $6 \%$ of the Cape's regional plant diversity - high tallies compared to other biodiversity hotspots. Most coastal-flora endemics emerged during the Plio-Pleistocene as a product of ecological speciation upon the colonization of calcareous substrata, with the calcifugous fynbos floras of montane acid substrata being the most significant source of this diversification, especially on the typically shallow soils of calcarenite landscapes. On the other hand, renosterveld floras, associated with edaphically benign soils that are widespread on the CFR lowlands, have not been a major source of lineages to the coastal flora. Our findings suggest that, over and above the strong $\mathrm{pH}$ gradient that exists 
45

46

47

48

49

50

51

52

53

54

55

56

57

58

59

60

61

62

63

64

65

66

67

68

69

70

71

72

73

74

75

on calcareous substrata, soil depth and texture may act as important edaphic filters to incorporating lineages from floras on juxtaposed substrata in the CFR.

\section{Introduction}

The coastal flora of the Cape Floristic Region (CFR), comprising species associated with calcareous substrata (coastal dunes and calcarenites), is the youngest manifestation of the immense radiation of the Cape flora. The endemic component of this coastal flora started diversifying only in the Plio-Pleistocene, when large tracts of calcareous substrata were exposed during the numerous sea-level regressions on the Palaeo-Agulhas Plain (PAP) (Marean, Cowling $\&$ Franklin, 2020) and its equivalent on the west coast (Dingle \& Rogers, 1972; Cowling, Procheş \& Partridge, 2009; Hoffmann, Verboom \& Cotterill, 2015; Cawthra et al., 2020). These calcareous lithologies comprised unconsolidated (mainly dune sands) and consolidated (mainly calcarenites) substrata, very different chemically from most CFR soils, which are acidic. Most biologists refer to these consolidated calcareous substrata - calcarenites - as "limestones", hence the term "limestone fynbos" (Cowling \& Heijnis, 2001; Rebelo et al., 2006).

The oldest radiations in the CFR are associated with the infertile, acid, sandy soils derived from the Cape Supergroup rocks (mainly quarzitic sandstone) that form the mountains of the Cape Fold Belt. These ancient floras, intimately associated with infertile montane habitats, acted as the source flora for most subsequent radiations on the lowlands during the Cenozoic, namely on silcretes (Oligocene) and shales (Mio-Pliocene) (Verboom, Linder \& Stock, 2004; Cowling, Procheş \& Partridge, 2009; Verboom et al., 2014; Hoffmann, Verboom \& Cotterill, 2015). While coastal dunes were probably present throughout the Cenozoic, the geomorphic evolution of the CFR during the Plio-Pleistocene resulted in what was likely the first large-scale occurrence of calcareous substrata along the Cape coast, providing novel habitats for plant colonization and ensuing diversification (Linder, 2003; Cowling, Procheş \& Partridge, 2009).

As is the case with other nutritionally unusual or regionally rare substrata (Kruckeberg \& Rabinowitz, 1985; Kruckeberg, 1986, 2002; Rajakaruna, 2018), colonizing calcareous substrata would have posed physiological challenges for the Cape flora (Thwaites \& Cowling, 1988; Deacon, Jury \& Ellis, 1992; Verboom, Stock \& Cramer, 2017), producing an assemblage 
characterised by high edaphic endemism (Cowling, 1983; Cowling, Holmes \& Rebelo, 1992; Cowling \& Holmes, 1992b; Willis, Cowling \& Lombard, 1996; Cowling et al., 2019). On the other hand, CFR coastal habitats were linked directly to the coastal habitats of the summerrainfall subtropical east coast (Cowling, 1983) and the winter-rainfall desert on the west coast of southern Africa (Jürgens, 1997), enabling colonization by these extra-Cape lineages during climatically suitable times in the Plio-Pleistocene. Furthermore, contemporary dune habitats incorporate floristic elements from abutting vegetation formations (forest, fynbos, grassland, renosterveld, succulent karoo and subtropical thicket) throughout the CFR (Bergh et al., 2014). As a result, we expect the coastal flora to have a strong representation of Cape lineages (fynbos, renosterveld elements) but augmented by species with desert (mainly succulent-karoo elements) and tropical (mainly subtropical-thicket and forest elements) affinities.

While there has been some research on the characteristics of the CFR's dune and calcarenite floras, these have been patchy. Aspects of the calcarenite flora, centred on the Agulhas (Thwaites \& Cowling, 1988) and Riversdale (Rebelo et al., 1991) coastal plains, have been studied in part by Cowling \& Holmes (1992a,b), Cowling, Holmes \& Rebelo (1992) and Willis, Cowling \& Lombard (1996), though no complete assessment of the flora has been undertaken. The distinctiveness of the calcarenite flora is clear from the work of Cowling (1990), who demonstrated nearly complete replacement of species assemblages between climatically and topographically similar sites on calcarenite and non-calcareous substrata of the Agulhas Plain. Further support for this is the recognition of the core area occupied by this flora as a centre of species endemism - termed the Bredasdorp-Riversdale (Cowling, Holmes \& Rebelo, 1992) or Agulhas Plain centre (Manning \& Goldblatt, 2012a) - for various Cape lineages (e.g., Dahlgren, 1963; Nordenstam, 1969; Rebelo \& Siegfried, 1990). Among substrata found on the Agulhas coastal plain, calcarenites harbour exceptionally high proportions of range-restricted edaphic endemics (Cowling \& Holmes, 1992b), much more so than matched sites in climatically similar southwestern Australia (Cowling et al., 1994). Willis, Cowling \& Lombard (1996) identified 110 calcarenite-endemic species in the calcarenite flora of the Agulhas and Riversdale coastal plains; these are especially well-represented in the Asteraceae, Ericaceae, Fabaceae and Rutaceae, but also include members of the Iridaceae and Proteaceae, and among genera, Agathosma, Aspalathus, Erica and Muraltia comprised most endemics. While the calcarenite flora is a 
107 unique assemblage of species, it shares the prominence of these higher taxa with other CFR 108 floras.

As with the calcarenite flora, no integrated study of the Cape dune flora exists. Most botanical

111 research has focused on strand and hummock-dune plant communities (Boucher \& Le Roux, 112 1993; Taylor \& Boucher, 1993; Lubke et al., 1997), with few studies exploring the floras of 113 vegetated back dunes (Cowling, 1983, 1984). Cowling et al. (2019) provided an analysis of a 114 coastal dune flora from the year-round rainfall southeastern CFR, with comparisons to two 115 winter-rainfall dune floras from the southwestern CFR. These dune floras have similar trait 116 profiles and are dominated by members of the Asteraceae, Fabaceae and Poaceae, while families 117 that are speciose in inland fynbos floras, such as Ericaceae and Restionaceae, are poorly 118 represented, or entirely lacking, as is the case for Proteaceae. Typical Cape genera that are 119 endemic or near-endemic to the Greater CFR (cf. Born, Linder \& Desmet, 2007; Colville et al., 2014) contribute a high proportion of species to dune floras in the region. These floras further

121 exhibit a high frequency of species endemic to the CFR (ca. 40\%) and high levels of edaphic endemism (ca. 30-40\% dune endemics), although both geographic and edaphic endemism are more pronounced in the winter-rainfall zone, especially among typical Cape lineages (sensu Linder, 2003). A peculiar feature of CFR dune floras is the prominence of species associated with tropical lineages, a pattern that persists even along the strongly winter-rainfall west and southwest coasts (e.g., Boucher \& Jarman, 1977), though the number of species associated with tropical lineages declines from east to west along a gradient of increasing winter rainfall (Cowling, 1983; Tinley, 1985; Cowling et al., 1997b; Vlok, Euston-Brown \& Cowling, 2003). This richness of tropical species, many of which are endemic to coastal dunes of the CFR, sets

130 Cape dune floras apart from those in other Mediterranean-climate ecosystems (MCEs) (Cowling 131 et al., 2019) and from other floras in the CFR (Cowling, 1983, 1984).

In summary, both calcarenite and coastal dunes in the Cape support floras that are typical of the region, yet there are apparent differences: calcarenite floras exhibit a relatively stronger Cape signature, while dunes have a strong representation of tropical elements. Despite these differences, floras associated with these substrata likely share ecological adaptations to their coastal and edaphically unique environment and experienced a common evolutionary history 
138 vastly different from that experienced by inland floras of the CFR. We therefore expect certain

139 idiosyncrasies to emerge that may shed further light on the most recent diversification event in 140 the Cape flora. Here, we present a unified flora of these coastal calcareous habitats of the CFR 141 and analyse the flora to assess its size, taxonomic composition, growth-form mix, biological 142 traits, biogeographic affinities and endemism. We further sketch a brief scenario of the flora's assembly, with a focus on the Pleistocene - a period whose dynamic sea levels and vacillating climate had a profound impact on the geography and diversification of floras in the Cape

145 (Cowling et al., 2017; Forest, Colville \& Cowling, 2018; Colville et al., 2020), especially along 146 the coast (Grobler et al., 2020).

We find that the Cape coastal flora is a diverse assemblage of 1,365 species, with high levels of edaphic and geographic endemism at various regional scales. Similar to other floras in the CFR, the coastal flora is taxonomically dominated by the Asteraceae, Fabaceae and Iridaceae and with Cape lineages (sensu Linder, 2003) like Erica, Aspalathus, and Agathosma being the most speciose genera. However, extra-Cape lineages from desert and tropical floras have contributed several members to the coastal flora in the CFR, with many of these species being endemic to the region. The calcicolous component, representing $40 \%$ of the coastal flora, appears to largely be the product of ecological speciation following the colonization of novel calcareous substrata during the Plio-Pleistocene. The ancient, calcifuge fynbos flora, associated with shallow, acid sands of the Cape Fold Belt, emerges as the most significant source of lineages to the coastal flora, while few lineages and species are shared with renosterveld floras found on neutral loams.

\section{Study area}

Our study area comprised coastal dune and calcarenite landscapes of the CFR (Figure 1). We used the delimitation of the CFR proposed by Colville et al. (2014), which includes the Cape Fold Belt mountains east of Algoa Bay and the coastal belt east of here to the Kei River. This region covers an area of ca. 106,000 km². Coastal calcareous substrata occupy ca. 4,500 km² (4\%) of the CFR, with areal coverage shared nearly equally between dunes $\left(2,200 \mathrm{~km}^{2}\right)$ and calcarenites $\left(2,300 \mathrm{~km}^{2}\right)$ (adapted from South African Council for Geoscience 1:250,000 
169

170

171

172

173

174

175

176

177

178

179

180

181

182

183

184

185

186

187

188

189

190

191

192

193

194

195

196

197

198

199

coastal aeolianites (Roberts et al., 2006). The CFR coastal lowlands were subjected to repeated marine transgressions and regressions throughout the Neogene, and especially during the interglacials and glacials of the Pleistocene (Partridge \& Maud, 2000). During Pleistocene lowstand sequences, vast areas of calcareous substrata were exposed on the Palaeo-Agulhas Plain (Marean, Cowling \& Franklin, 2020) along the southern margin of the contemporary CFR (Cawthra et al., 2020) (Figure 1). The long-term exposure of these markedly more expansive calcareous habitats and the recurrent disturbance associated with sea-level fluctuations during the Pleistocene have likely had a profound impact on the evolution of the contemporary coastal flora in the Cape (Grobler et al., 2020).

Coastal dunes occur along the entire CFR coast, but are best developed along the south coast where they are associated with embayments, especially Walker Bay, Still Bay, the WildernessSedgefield embayment, St Francis Bay and Algoa Bay (Tinley, 1985; Roberts et al., 2006). South-coast dunes are typically broad, high, vegetated, unidirectional parabolic dunes that form shore-parallel cordons (also known as 'barrier dunes'). The monoclinal southwest and southeast coasts, on the other hand, generally host smaller dunes: plumes of low, vegetated hairpin dunes, often extending some distance inland, predominate in the southwest (Elands Bay to Table Bay and False Bay), while a narrow cordon of densely vegetated, bidirectional parabolic dunes is typical of the far southeast (east of Algoa Bay) (Tinley, 1985; Roberts, Cawthra \& Musekiwa, 2014). Most extant coastal dunes are geologically young, with their deposition precipitated by rising sea levels since the terminal Pleistocene and start of the Holocene (Roberts, Cawthra \& Musekiwa, 2014). Our interest lies in these young dunes and not older Neogene dunes that have been subjected to leaching and oxidization through long-term weathering (Tinley, 1985) and whose floras are therefore similar to non-calcareous, inland habitats of the CFR (Cowling \& Holmes, 1992a).

While calcarenites are present along most of the Cape coastal margin (Brooke, 2001), the most significant exposures occur on the Agulhas and Riversdale coastal plains of the south coast, with smaller outcrops on the southwest coast around the Saldanha Peninsula, and on the southeast coast inland of Algoa Bay (Roberts et al., 2006; Roberts, Cawthra \& Musekiwa, 2014)

(Figure 1). These formations and their associated colluvial deposits form distinctive relief 
200 features, especially along the south coast, where they comprise elongate, shore-parallel,

201 transverse ridges extending up to $15 \mathrm{~km}$ inland (Roberts et al., 2006; Roberts, Cawthra \&

202 Musekiwa, 2014). They are interpreted as highstand deposits dating primarily from the Pliocene.

203

204 Soils associated with coastal dunes and calcarenites are similar, comprising well-drained, coarse-

205 to medium-grained, alkaline ( $\mathrm{pH} 7-8)$ sands with moderate levels of available phosphorous (5-

$20620 \mathrm{ppm}$ ), though dune soils are mostly deep (>1 m), while soils overlying calcarenites are much

207 shallower (<0.3 m) (Cowling, 1984; Tinley, 1985; Thwaites \& Cowling, 1988) (Table 1).

208 Colluvial sands that fringe calcarenite ridges are deeper $(>0.3 \mathrm{~m})$, moderately leached and

209 neutral (Thwaites \& Cowling, 1988).

210

211 The climate varies from winter-rainfall in the southwest (Elands Bay to Cape Agulhas) to a non-

212 seasonal rainfall regime where the proportion of summer precipitation increases eastward, but

213 with rainfall peaks in autumn and spring (Deacon, Jury \& Ellis, 1992; Schulze, 2008; Bradshaw

$214 \&$ Cowling, 2014). Mean annual precipitation varies from 300-800 mm, with lowest rainfall in

215 the west around the Saldanha Peninsula $(300 \mathrm{~mm})$ and along the south coast between Cape

216 Agulhas and Mossel Bay (300-500 mm), and highest rainfall in the east toward the mouth of the

217 Kei River $(800 \mathrm{~mm})$ (Schulze, 2008). On the semi-arid west coast, fog is an important source of

218 moisture, especially during autumn and summer (Rebelo et al., 2006; Bradshaw \& Cowling,

219 2014). Temperatures are generally mild with mean temperatures ranging from $18-22{ }^{\circ} \mathrm{C}$ in

220 midsummer and $14-16^{\circ} \mathrm{C}$ in midwinter, although mean daily maxima are ca. $26^{\circ} \mathrm{C}$ during

221 summer and mean daily minima ca. $8^{\circ} \mathrm{C}$ during winter (Rebelo et al., 2006; Schulze, 2008). Due

222 to the strong marine influence, frost is a rare phenomenon. Strong winds and gales are common

223 during summer (easterly winds) and winter (westerly winds), although the central region (Mossel

224 Bay to Tsitsikamma) generally has a calmer wind regime (Schulze, 2008).

225

226 Coastal dune vegetation predominantly comprises a mosaic of two biomes, namely Fynbos and

227 Subtropical Thicket, termed 'dune fynbos-thicket mosaic' (Cowling, 1984; Tinley, 1985;

228 Cowling et al., 1988; Rebelo et al., 1991; Vlok, Euston-Brown \& Cowling, 2003; Zietsman \&

229 Bredenkamp, 2006). The former is a low, fire-prone shrubland dominated by evergreen, small-

230 leaved shrubs occurring mostly in fire-exposed and edaphically dry sites (Figure 2 A), while the

PeerJ reviewing PDF | (2021:05:60924:1:1:NEW 7 Jul 2021) 
231 latter is a medium to high, dense, closed-canopy shrubland dominated by evergreen, large-leaved

232 shrubs occurring in mesic, fire-protected sites (Figure $2 \mathrm{~B}$ ). Where ample moisture is available

233 and fire is excluded for long periods, dune thicket can attain forest stature. Grasslands are largely

234 a feature of the southeastern CFR coast (St Francis Bay to Kei River) and become increasingly

235 dominant on dunes east of Algoa Bay (Vlok, Euston-Brown \& Cowling, 2003). Coastal dune

236 landscapes further support various wetland types as well as distinctly coastal habitats, including

237 mobile bypass dunes, semi-mobile hummock dunes above sandy shores, and semi-succulent

238 herblands and shrublands above rocky shores.

239

240

241

On the south coast (False Bay to Mossel Bay), vegetation associated with calcarenites comprises a distinct Fynbos-biome formation known as 'limestone fynbos' (Rebelo et al., 2006). It generally comprises fire-prone, tall, evergreen shrublands dominated by overstorey proteoid shrubs (Leucadendron, Leucospermum, Protea) (Cowling et al., 1988; Rebelo et al., 1991) (Figure $2 \mathrm{C}, \mathrm{D}$ ). As is the case with coastal dunes, calcarenite landscapes may also support pockets of subtropical thicket or forest in moist, fire-sheltered sites, although these are far more restricted in extent than is the case for dunes. On the semi-arid west coast around the Saldanha Peninsula, calcarenites support 'strandveld' - a low, succulent-rich, subtropical-thicket shrubland (Boucher \& Jarman, 1977; Rebelo et al., 2006) (Figure 2 E). Calcarenites occurring inland of Algoa Bay on the southeast coast support a mosaic of subtropical thicket, typically occurring as small rounded clumps in dolines (Carvalho \& Campbell, 2021), and a grassy, succulent-rich dwarf-shrubland (Taylor \& Morris, 1981; Vlok, Euston-Brown \& Cowling, 2003) (Figure 2 F).

252

As alluded to in the preceding paragraphs, and as is the case in the CFR more generally (Kraaij \& Van Wilgen, 2014), fire plays an important role in the functioning of ecosystems occurring in dune and calcarenite landscapes of the Cape's coastal forelands. All habitats in these landscapes, other than the forest patches, wetlands, bypass dunes, hummock dunes and near-shore herb- and shrublands, are subject to wildfires at moderate intervals (10-30 years) (Cowling et al., 1997a, 2019). The fire ecology of calcarenite grassy-shrubland-thicket mosaics inland of Algoa Bay is poorly understood, but the incidence of fire-dependent Cape lineages (e.g., Diosmeae, Muraltia, Restionaceae) (sensu Linder, 2003) in the matrix vegetation (Taylor \& Morris, 1981) and the 
262 - in thicket clumps (Taylor \& Morris, 1981; Carvalho \& Campbell, 2021) suggest that fire is a

263 periodic disturbance in this system. Kraaij et al. (2020) have proposed that historical fire regimes

264 on coastal lowlands in the southern Cape supported fire-prone and -dependent vegetation

265 throughout the Pleistocene, including dune fynbos-thicket mosaics and limestone fynbos

266 analogous to those of the contemporary CFR (Cowling et al., 2020). Thus, as in the CFR more

267 generally (Bytebier et al., 2011; He, Lamont \& Manning, 2016; Rundel et al., 2018), fire has

268 been an important factor shaping the evolution of the Cape's coastal flora.

269

270

Methods

\section{Flora compilation}

272 Our flora (including only native flowering plant species) of coastal calcareous substrata was

273 compiled from a variety of sources including scientific literature, online databases and personal

274 photographic records. The primary source was the most recent plant conspectus for the CFR

275 (Manning \& Goldblatt, 2012a). However, the authors of this work used a narrower

276 circumscription of the CFR than we do (cf. Colville et al., 2014), essentially excluding the

277 coastal mountains and lowlands between Port Elizabeth and the Kei River. We therefore also

278 referred to the most recent plant conspectus for the Eastern Cape Province (Bredenkamp, 2019),

279 which encompasses this eastern coastal extension of the CFR. Both floras include habitat

280 descriptions for plant species, which we queried for relevant terms, namely "alkaline", "beach",

281 "calcareous", "coastal", “dune", "limestone" and "strand". The term "coastal" often included

282 species not present on calcareous substrata, which we excluded from our flora. These are species

283 associated with leached, siliceous cover sands that blanket patches of coastal foreland - typically

284 inland of the coastal calcareous substrata - on both the west and the south coasts of the CFR.

285 Thus, the floras associated with Sand Fynbos vegetation types (cf. Rebelo et al., 2006) were not

286 included. We also excluded species that occur only east of Algoa Bay (the Sundays River),

287 typically of tropical affinity and associated with coastal forests (e.g., Eugenia capensis,

288 Mimusops obovata, Strelitzia nicolai).

289

290 The list of species derived from these two conspectuses were supplemented with floras for

291 coastal dune habitats produced by Olivier (1983), Van Wijk et al. (2017) and Cowling et al.

292 (2019), and by incidental species lists produced during vegetation surveys in coastal dune and

PeerJ reviewing PDF | (2021:05:60924:1:1:NEW 7 Jul 2021) 
293 calcarenite habitats (Zietsman \& Bredenkamp, 2006, 2007; Mergili \& Privett, 2008). While no

294 structured field work was undertaken for this study, we also included georeferenced

295 photographic records of species collected by us from 2009-2021. Species were identified by us

296 from photographs and these photographic records (1,631 records of 506 species) were collated in

297 an online biodiversity records database, iNaturalist

298 (https://www.inaturalist.org/observations?q=CFR_coastal_flora\&user_id=adriaan_grobler),

299 where they were (and are) available for scrutiny by other botanists. Select species records from

300 other iNaturalist contributors, which were manually inspected and verified by us, were also

301 included.

302

303 We further verified the edaphic occurrence of species for key taxonomic groups from various

304 descriptions, revisions and monographs (Levyns, 1954; Nordenstam, 1968; Grau, 1973;

305 Verdoorn, 1980; Puff, 1986; Linder, 1990; Schubert \& Wyk, 1997; Linder \& Mann, 1998;

306 Whitehouse, 2002; van Jaarsveld \& Koutnik, 2004; Goldblatt \& Manning, 2007, 2010, 2011;

307 Manning, Goldblatt \& Forest, 2009; Manning \& Goldblatt, 2010, 2012b; Köcke et al., 2010;

308 Nkonki, 2013; Wolfe, 2013; Fish et al., 2015; Bello et al., 2017; Stirton \& Muasya, 2017; Bergh

309 \& Manning, 2019; Manning, 2019; Alonso et al., 2021), adding those species that were not

310 included during the previous steps. As a final verification, two speciose families in our flora

311 were checked by taxonomic experts to assess the validity of species we included (Ericaceae,

312 checked by Ross C. Turner; Rutaceae, checked by Terry H. Trinder-Smith). These experts also

313 verified traits of species, as described below, for their focal taxa. We included putatively

314 undescribed species in our flora; where these were derived from our own observations, we

315 communicated with experts to confirm their taxonomic placement (Charles H. Stirton,

316 Otholobium sp. nov. 'algoensis'). The primary source for each species included in our flora is

317 indicated in Data S1. Nomenclature in our flora follows the Plants of Southern Africa database

318 provided by the South African National Biodiversity Institute (http://posa.sanbi.org).

\section{Biological traits}

321 Species were categorized into five herbaceous and five woody growth forms. Classifications

322 were based on information from the literature (listed under "Flora compilation") and from our

323 observations in the field. In the case of species with high phenotypic plasticity, we assigned to it 
324 the growth form that is most prevalent throughout our study area. As an example, Sideroxylon

325 inerme, which takes many forms - from a dwarf multi-stemmed shrub to a tall single-stemmed

326 tree - most commonly grows as a tall, multi-stemmed shrub in our study area and was

327 categorized as such. Herbaceous growth forms comprised evergreen hemicryptophytes,

328 deciduous hemicryptophytes, geophytes, annuals, forbs and vines. Woody growth forms were

329 trees (mostly single-stemmed, $>5 \mathrm{~m}$ height), tall shrubs (2-5 m height), low shrubs (0.5-2 m

330 height), dwarf shrubs $(<0.5 \mathrm{~m})$ and lianas. Herbaceous and woody species exhibiting succulence

331 (leaf or stem), and putatively employing CAM photosynthesis (Mooney, Troughton \& Berry,

332 1977), were additionally classified as succulents.

333

334 We further classified woody species according to their postfire-regeneration mode, using a

335 simplified version of Pausas et al.'s (2016) schema to match the resolution of information

336 available to us. Species were categorized as obligate resprouters (plants exclusively resprout

337 after fire, recruit from seeds in favourable microsites during fire-free intervals), facultative

338 seeders (plants capable of resprouting and establishing seedlings after fire) and non-sprouters

339 (plants killed by fire and reliant on seeds for regeneration, including obligate seeders and postfire

340 colonizers), based in part on the literature (Cowling \& Pierce, 1988; Strydom et al., 2020; works

341 listed under "Flora compilation"), but largely following our own observations after several

342 wildfires at various sites along the Cape south coast between 2016 and 2021. Regeneration

343 modes of Aspalathus species were gleaned from supplementary data provided by Cowling et al.

344 (2018).

345

346 Geographical traits

347 Using habitat descriptions from the literature (listed under "Flora compilation") and based on our

348 observations throughout the study area, species were allocated to one of the following biomes:

349 Fynbos, Subtropical Thicket (hereafter 'Thicket'), Forest, Grassland, Coastal, Wetland or

350 Disturbed. While most species have a strong affinity for a specific biome, others may occur in

351 multiple biomes (e.g., Pterocelastrus tricuspidatus, which is found in Thicket and Forest); in

352 such cases, species were assigned to the biome in which they are most prevalent throughout the

353 study area (Thicket, in the case of P. tricuspidatus).

354

Peer] reviewing PDF | (2021:05:60924:1:1:NEW 7 Jul 2021) 
355 Species were further categorized according to the distribution of their respective genera in 356 relation to phytogeographic regions, based on information from Goldblatt (1978), Manning \& 357 Goldblatt (2012a), and Bredenkamp (2019). A species was assigned to one of seven regions to 358 which its genus is endemic or near-endemic. The seven regional categories used were: Greater 359 Cape Floristic Region (GCFR - comprising the CFR and adjacent winter-rainfall semi-desert 360 region); Southern Africa (roughly corresponding to the countries of South Africa, Lesotho,

361 Eswatini, Botswana and Namibia, and thus including the GCFR as a subset); Afrotemperate 362 (disjunct montane regions embedded in Southern Africa and the Afrotropical region, extending 363 from the CFR northward through the Drakensberg range to the East African Rift System and the 364 highlands of Cameroon, Guinea and Ethiopia); Afrotropical (roughly corresponding to sub365 Saharan Africa, including tropical and subtropical enclaves in Southern Africa, but excluding the 366 Afrotemperate region); Pantemperate (temperate regions beyond Africa); Pantropical (tropical 367 regions beyond Africa); and Cosmopolitan (globally widespread).

We also classed species based on their distribution within the GCFR, identifying those endemic to: the entire region; only the CFR; and those with distributions extending beyond the GCFR 371 (i.e., non-endemic). Additionally, species endemic to single centres within the CFR (Agulhas

372 Plain Centre, Southeastern Centre, Southwestern Centre; Figure 1) were identified, as were local373 endemic species. We define the latter as those species that are restricted to a single CFR centre 374 with a lower-than-average range size in which the extent of occurrence is typically $<2,000 \mathrm{~km}^{2}$

375 (Cowling, 2001). Note that select species included in this category have extremely small range sizes $\left(<5 \mathrm{~km}^{2}\right)$ and may be regarded as point endemics.

\section{Edaphic traits}

379 Species were assigned to edaphic categories corresponding to four broad, biologically relevant 380 soil types found on the coastal lowlands of the CFR (Table 1) (cf. Deacon, Jury \& Ellis, 1992; cf. 381 Cawthra et al., 2020; cf. Cowling et al., 2020). Groups are based on soil texture, fertility, pH and depth, and include: (1) moderately fertile, alkaline sands associated with coastal dunes (typically deep) and calcarenites (typically shallow); (2) shallow, acidic, infertile sands associated with quartzitic sandstones; (3) deep, acidic, infertile windblown cover sands; and (4) deep to shallow, neutral, fertile loams associated with shales, mudstones and conglomerates. These categories 
386

387

388

389

390

391

392

393

394

395

396

397

398

399

400

401

402

403

404

405

406

407

408

409

410

411

412

413

414

415

416

were not mutually exclusive, with some species occurring on multiple soil types. Species occurring on alkaline sands were also scored for edaphic endemism on coastal dunes and on calcarenites. Again, these were not mutually exclusive, with some calcicoles occurring on both calcareous substrata (but being restricted to them).

\section{Data analysis}

All data analysed in this study are available in Data S1. We performed our analyses using R version 4.1.0 statistical software (R Core Team, 2021), with additional use of the 'tidyverse' version 1.3.1 (Wickham et al., 2019), 'janitor' version 2.1.0 (Firke, 2021), 'treemapify’ version 2.5.5 (Wilkins \& Rudis, 2021), 'igraph’ version 1.2.6 (Csardi \& Nepusz, 2006), ggraph version 2.0.5 (Pedersen, 2021) and 'patchwork' version 1.0.1 (Pedersen, 2020) R packages for data cleaning, wrangling, analysis and visualization.

\section{Results}

\section{Floristic composition}

The coastal flora of the CFR comprises 1,365 species, 435 genera and 102 families (the full list of species is presented in Data S1). The largest families are the Asteraceae (198 spp.), Fabaceae (103 spp.), Iridaceae (76 spp.), Rutaceae and Scrophulariaceae (both 61 spp.), Aizoaceae (59 spp.), Poaceae (53 spp.) and Cyperaceae (47 spp.) (Figure 3; Table S1). Together, these eight families - representing less than a tenth of the coastal flora families - account for nearly half of the species (658 spp.), while the 20 most speciose families (a fifth of coastal flora families) contribute nearly $70 \%$ of species ( 946 spp.) in the flora. In contrast, half (52 families) of the recorded families comprise fewer than five species, with most of these ( 27 families) represented by a single species. Thus, relatively few families account for the bulk of species in the Cape coastal flora, while most families contribute only a few species.

Patterns of family size remain similar when comparing numbers of genera (Figure 3; Table S1): the Asteraceae contributes the most genera (53 genera) to the coastal flora, while the Poaceae (30 genera), Fabaceae (22 genera), Aizoaceae (19 genera), Iridaceae (16 genera), Cyperaceae (14 genera) and Scrophulariaceae (13 genera) are also genus-rich. The Apiaceae, while being relatively species-rich (29 spp.), ranks higher among families for generic richness (15 genera), 
417 and the Rutaceae, one of the most speciose families, ranks lower (9 genera). Most families

418 (90 families) are represented by fewer than 10 genera, with most of these (61 families)

419 comprising only one or two genera. Families represented by a single genus total 47 .

420

421 The most speciose genera in the Cape coastal flora are Erica and Aspalathus (both 28 spp.),

422 Agathosma (26 spp.), Senecio (25 spp.), Helichrysum (24 spp.), Indigofera (23 spp.) and

423 Hermannia (22 spp.) (Figure 3; Table S1). These genera represent less than 2\% of genera

424 recorded in the coastal flora but comprise 13\% (176) of species. The 20 largest genera (5\% of

425 coastal flora genera) account for $27 \%$ of species (366 spp.), while nearly half (216 genera) of the 426 genera in the coastal flora are represented by a single species.

427

428 The overall ratio of species to genera (S/G-ratio) in the Cape coastal flora is 3.1, with most 429 families (73 families) in the flora having an S/G-ratio lower than this. For nearly a third of 430 coastal flora families (29 families), the S/G-ratio is higher than that of the whole flora 431 (Table S1). Most notable are the Ericaceae (28.0), Polygalaceae and Asparagaceae (both 13.0), 432 and Oxalidaceae (12.0), though importantly, these families all contribute only one 433 (Asparagaceae, Ericaceae, Oxalidaceae) or two (Polygalaceae) genera to the flora. Of the ten 434 most speciose coastal flora families, only the Rutacaeae has a comparatively high S/G-ratio (6.8), 435 with the ratio for the remaining nine families ranging from 1.8-4.8.

\section{Biological traits}

Herbaceous growth forms comprise about half (49\%, 667 spp.) of the flora (Figure 4 A). Among herbaceous species, geophytes are most numerous (30\%, 199 spp.), with strong representation of the Iridaceae (Moraea, Gladiolus), while the Hyacinthaceae, Orchidaceae and Amaryllidaceae are also prominent in the geophytic flora. The bulk of geophytes are thus petaloid monocots, though some dicots (Oxalis, Othonna, Pelargonium) do occur. A quarter (25\%, 165 spp.) of herbaceous species are forbs, with most being members of the Asteraceae. Hemicryptophytes constitute $21 \%$ of herbs; most of these (12\% of herbs, 81 spp.) are evergreen (Cyperaceae, Restionaceae), while deciduous species (mainly Poaceae) make up a slightly smaller proportion 446 (9\% of herbs, 62 spp.). About 18\% of herbaceous species (122 spp.) in the coastal flora are 447 annuals, with the annual flora dominated by the Asteraceae and Scrophulariaceae. Vines - 
448 typically associated with forest and thicket - comprise nearly $6 \%$ of herbs (38 spp.), with most of 449 these herbaceous climbers belonging to the Apocynaceae.

450

451

Just over half of the coastal flora are woody species (51\%, $698 \mathrm{spp}$.), with dwarf shrubs (47\% of 452 woody species, $330 \mathrm{spp}$.) and low shrubs (36\% of woody species, $253 \mathrm{spp}$.) making up the bulk 453 of these (Figure 4 B). Among dwarf shrubs, the Fabaceae (Indigofera, Aspalathus) is most 454 species-rich, followed by the Aizoaceae and Asteraceae. The Asteraceae (Helichrysum) and 455 Fabaceae (Aspalathus) also contribute several low shrubs to the coastal flora, as does the 456 Rutaceae (Agathosma, Diosma, Euchaetis). About 10\% of woody species are tall shrubs 457 (69 spp.), most of which are members of the Asteraceae (Metalasia) but also include Proteaceae 458 (Leucadendron), though several belong to typical thicket families (Celastraceae, Anacardiaceae, 459 Ebenaceae). The tree flora - an exclusive feature of the Forest biome - is sparse, comprising 460 only 20 species (3\% of woody species) and with no taxonomic groups being dominant. Lianas 461 account for 4\% (26 spp.) of woody species, and so climbing plants (lianas and vines) constitute 462 nearly 5\% (64 spp.) of the CFR coastal flora. The genus Asparagus (Asparagaceae) is especially diverse among lianas.

464

Nearly half (47\%, $325 \mathrm{spp}$.) of woody species in the coastal flora are facultative seeders, most being associated with the Fynbos biome (Figure 4 C). Similarly, the bulk of seed-reliant nonresprouters, which make up 40\% (276 spp.) of woody species, are associated with fynbos. Obligate resprouters, typically tall shrubs and trees of tropical origin associated with thicket and forest, comprise 14\% (97 spp.) of woody species in the coastal flora.

Succulents, which include both herbaceous and woody growth forms, comprise 116 species (8\% of the flora) (Figure 4 D). About a third of succulents are herbaceous (41 spp.), while the bulk are woody (75 spp.). Most succulent species are members of the Aizoaceae (Ruschia, Delosperma, Lampranthus, Mesembryanthemum, Tetragonia), but Crassulaceae (Cotyledon, Crassula) and Asphodelaceae (Aloe, Bulbine) also feature prominently. Most species are leafsucculents, with only a few Euphorbia species being stem-succulents.

\section{Geographical traits}


479 Species associated with the Fynbos biome constitute most of the CFR coastal flora (64\%, 873 480 spp.) (Figure 5 A), represented mainly by the Asteraceae (Helichrysum, Senecio), Fabaceae 481 (Aspalathus, Indigofera), Rutaceae (Agathosma, Diosma), Iridaceae (Moraea, Gladiolus) and 482 Scrophulariaceae. The Thicket biome houses 11\% (153 spp.) of the flora, with members of the 483 Apocynanceae, Anacardiaceae (Searsia), Celastraceae, and Asparagaceae (Asparagus) well 484 represented. A small but distinct suite of species is associated with the Forest biome, accounting 485 486 487 488 489 490 491 492 493 494 495 496 497 498 499

500

501

502

503

504

505

506

507

508 509 for 5\% (73 spp.) of the coastal flora, including mostly members of tropical genera (Apodytes, Erythrina, Maurocenia, Psychotria), but also Afrotemperate elements (Afrocarpus). The Cyperaceae, Asteraceae and Amaranthaceae dominate the Wetland biome, which hosts 8\% (111 spp.) of species. The flora of the Coastal biome, hosts about 5\% (69 spp.) of species, most of which belong to the Asteraceae, Aizoaceae and Poaceae. The Grassland biome - largely a feature of the southeastern CFR - comprises nearly 4\% (51 spp.) of the coastal flora and is characterized by a high number of Poaceae with tropical origins $\left(\mathrm{C}_{4}\right.$-genera, e.g., Cymbopogon, Eragrostis, Themeda). Ruderal species typical of disturbed areas (e.g., paths, roadsides or patches of recently cleared vegetation) constitute less than 3\% (35 spp.) of the flora, with the Aizoaceae (Galenia) and Asteraceae (Berkheya, Senecio) being most frequent.

Most species in the Cape coastal flora belong to 124 genera endemic or near-endemic to the Greater Cape Floristic Region (GCFR) (35\%, 474 spp.) (Aspalathus, Erica, Agathosma, Muraltia) and 85 genera endemic to the Southern African Region (26\%, 348 spp.) (Hermannia, Ficinia, Moraea, Crassula); more than $60 \%$ of species in the flora thus have a southern-African affinity (Figure 5 B). Cosmopolitan genera (e.g., Cyperus, Polygala, Senecio) comprise 11\% (155 spp.) of species. Temperate lineages contribute close to 15\% (201 spp.) of the flora, with species shared equally between 44 pantemperate (e.g., Wahlenbergia, Silene, Limonium) and 24 Afrotemperate genera (e.g., Helichrysum, Gladiolus, Albuca). Nearly 14\% of species belong to tropical lineages, most of which $(9 \%, 125$ spp.) are associated with 76 pantropical genera (e.g., Diospyros, Olea, Ipomoea), and a smaller number (5\%, 62 spp.) with 29 Afrotropical genera (e.g., Asparagus, Searsia, Maerua).

Species endemic to the GCFR constitute about 73\% (990 spp.) of the flora, most of which are CFR-endemics (810 spp., 59\% of the total flora) (Figure 5 C). Many species are endemic to a 
510 single phytogeographic centre within the CFR (376 spp., 28\%), with the Agulhas Plain Centre

511 (AP) housing most of these (207 spp.), followed by the Southwestern (SW) (86 spp.) and

512 Southeastern (SE) Centres (84 spp.). Several of these centre-endemic species (196 spp.) have

513 notably restricted distributions (i.e., local endemics), with their regional richness reflecting that

514 of centre endemics: most local endemics occur in the AP (119 spp.), followed by the SW (51

515 spp.) and SE (26 spp.). None of the species occurring in the coastal flora are endemic to the

516 Northwestern Centre. The genera Erica (23 centre-endemic spp., 16 local-endemic spp.),

517 Agathosma (18 spp., 10 spp.), Aspalathus (15 spp., 10 spp.), Indigofera (14 spp., 6 spp.),

518 Muraltia (11 spp., 8 spp.) and Phylica (9 spp., 5 spp.) are strongly represented among range-

519 restricted species.

520

521 Edaphic traits

522 Species that are edaphically widespread - those occurring on calcareous substrata as well as

523 other soils of the CFR - make up $60 \%$ of the flora (817 spp.) (Figure 6 A). Most of the edaphic-

524 wides (382 spp., 28\% of the flora) show no affinity for specific substrata and occur on all soil

525 types. Of the 436 remaining edaphically widespread species (Figure 6 B), most occur elsewhere

526 on deep, windblown acid sands (CS; 285 spp.) and/or sandstone-derived acid sands (SS;

527249 spp.), while those that occur on neutral loams (SH; 113 spp.) are less common in the coastal

528 flora. Among these species, three prominent edaphic groups emerge: (1) species typically

529 associated with calcareous sands as well as deep and shallow acid sands (CC + CS + SS) (140

530 spp., 10\%); (2) species occurring only on calcareous sands and deep, acid sands (CC + CS) (104

531 spp., 8\%); and (3) species found on calcareous sands and shallow, sandstone-derived acid sands

$532(\mathrm{CC}+\mathrm{SS})(79$ spp., 6\%). Species shared between calcareous sands and neutral loams $(\mathrm{CC}+\mathrm{SH})$

533 (42 spp.), and those shared between calcareous sands, neutral loams and windblown acid sands

$534(\mathrm{CC}+\mathrm{SH}+\mathrm{CS})(41 \mathrm{spp}$.) comprise the same, relatively small proportion of the flora (both $3 \%$ ).

535 Edaphic-wides that occur elsewhere on neutral loams and sandstone-derived acid sands (CC +

$536 \mathrm{SH}+\mathrm{SS}$ ) are least frequent in the coastal flora (30 spp., 2\%).

537

538 About 40\% (548 spp.) of species in the CFR coastal flora are endemic to calcareous substrata,

539 with their occurrence shared equally among dunes and calcarenites (both 24\% of total flora); of

540 these, 104 species ( $8 \%$ of total flora) occur on both dunes and calcarenites (Figure 6 A). Dune-

PeerJ reviewing PDF | (2021:05:60924:1:1:NEW 7 Jul 2021) 
541 endemics total 226 species (17\% of total flora), while 218 species ( $16 \%$ of total flora) are

542 endemic to calcarenites (note that these tallies exclude the 104 calcicolous species occurring on

543 both dunes and calcarenites).

544

545 The calcicolous component

546 Most (52\%) of the 548 calcicolous species - those restricted to calcareous substrata - are

547 members of the Asteraceae (82 spp.), Fabaceae (46 spp.), Aizoaceae (41 spp.), Rutaceae (41

548 spp.) and Iridaceae (27 spp.) (Figure 7 A; Table S2). It is noteworthy that the Scrophulariaceae,

549 Poaceae and Cyperaceae, three cosmopolitan families, comprise several calcicoles (24, 18 and

55010 spp., respectively), as do typical Cape families like the Ericaceae (24 spp.), Proteaceae

551 (11 spp.) and Restionaceae (16 spp.). Interestingly among calcicolous graminoids, a third of

552 calcicolous grasses belong to the genus Pentameris (6 spp.), while most calcicolous sedges

553 belong to the genus Ficinia (6 spp.), both typical Cape lineages.

554

555 While there are similarities in the familial composition between the calcarenite-endemic and the

556 dune-endemic portions of the coastal flora (Figure 7 C, D; Table S3), for example the dominance

557 of the Asteraceae and prominence of the geophytic Iridaceae, there are also important

558 differences. Cape families, such as the Ericaceae, Fabaceae, Restionaceae and Rutaceae, are

559 more pronounced in the calcarenite-endemic flora, while the Proteaceae, which is rich in

560 calcarenite-endemics, is, apart from sporadic occurrences of Leucadendron coniferum on dunes

561 along the Cape Peninsula and the western Agulhas Plain coast, absent from the dune flora. On

562 the other hand, cosmopolitan families like the Asteraceae and Poaceae, the pantropical

563 Celastraceae, and the largely southern-African succulent families Aizoaceae and Asphodelaceae,

564 are more prominent in the dune-endemic flora. Additionally, the Amaranthaceae and

565 Plumbaginaceae (Limonium), families with several salt-tolerant members, occur in the dune-

566 endemic flora ( 3 and 4 spp., respectively), but contribute no calcarenite-endemic species (though

567 four calcicolous Limonium species also occur on calcarenites).

568

569 All calcicolous Ericaceae belong to Erica (24 spp.) - the genus contributing the greatest number

570 of calcicoles to the coastal flora - with most species being endemic to calcarenites (19 spp.). The

571 same is true for Aspalathus (12 of $16 \mathrm{spp}$. are calcarenite endemics), Muraltia (7 of $12 \mathrm{spp}$.), 
572 Phylica (6 of 9 spp.), Diosma (5 of 6 spp.) and Euchaetis (4 of 6 spp.). In other calcicole-rich

573 genera, the split between calcarenite- and dune-endemic species is more equal, for example

574 Indigofera (6 and 4 spp., respectively of 12 spp. total) and Hermannia (5 and 4 spp., respectively

575 of 10 spp. total). In Agathosma - the second richest genus in terms of calcicoles - most species

576 are restricted to calcarenites (10 of 19 spp.), although several are dune-endemics (4 spp.) or

577 calicole ubiquists (5 spp.). Searsia, a genus with subtropical affinities, contributes seven

578 calcicoles to the flora, with most species ( 5 spp.) occurring on both calcarenites and dunes. Dune

579 endemism is pronounced in the calcicole-rich asteraceous genera Helichrysum ( 7 of 9 spp. are

580 dune endemics) and Senecio (8 of 12 spp.), while the same is true for Wahlenbergia (4 of $6 \mathrm{spp}$.)

581 and the $\mathrm{C}^{3}$-grass genus Pentameris (4 of 6 spp.).

582

583 Compared to the whole coastal flora, the calcicolous component shows a stronger biogeographic

584 affinity to the Greater Cape, with nearly half (49\%, $267 \mathrm{spp}$.) of calcicoles belonging to genera

585 typical of the GCFR. This is pronounced in the calcarenite-endemic flora (examples shown in

586 Figure 8), where 64\% (139 spp.) belong to GCFR-genera, while the Greater-Cape affinity in the

587 dune-endemic flora (35 \%, 78 spp.) (examples shown in Figure 9) is the same as that of the

588 whole coastal flora. Species belonging to tropical genera comprise 8\% (43 spp.) of calcicoles -

589 about half the proportion in the rest of the coastal flora. The affinity to tropical floras is evident

590 among dune-endemics (11\%, 25 spp.), but muted among calcarenite-endemics (<3\%, 6 spp.).

591

592 Calcicolous species in the Cape coastal flora are overwhelmingly GCFR-endemics (92\%,

593506 spp.), with a large majority of these species being restricted to the CFR ( $84 \%$ of calcicoles,

594461 spp.). Calcicolous species with distributions that extend beyond the GCFR are largely

595 associated with dunes (33 spp.), with a smaller number occurring on both dunes and calcarenites

596 (9 spp.), though none are calcarenite endemics. More than a third (35\%, $194 \mathrm{spp}$.) of calcicolous

597 species are endemic to the Agulhas Plain centre (AP), most of them being calcarenite-endemic

598 species (164 spp.) and only a few being dune endemics (14 spp.). The Southeastern (SE) and

599 Southwestern centres (SW) each have about 11\% (each 59 spp.) of calcicoles endemic to them.

600 Dune endemism (44 spp.) is pronounced among SE-endemic calcicoles, while the number of

601 calcarenite endemics (4 spp.) is low. Among SW-endemic calcicoles, numbers of species

602 restricted to calcarenites (21 spp.) and dunes (29 spp.) are comparable. Levels of local-endemism

PeerJ reviewing PDF | (2021:05:60924:1:1:NEW 7 Jul 2021) 
603 are highest among AP-endemic calcicoles (112 spp.), followed by SW- (44 spp.) and SE-

604 endemic calcicoles (22 spp.).

605

606

607

Most calcicoles are dwarf shrubs (35\%, 193 spp.) or low shrubs (19\%, 104 spp.), both among calcarenite- and dune-endemic species. Forbs (12\%, 68 spp.) and geophytes (11\%, 59 spp.) are

608 common in the calcicolous flora, with the former being primarily dune endemics (48 spp.) and 609 the latter split more equally between calcarenite- (22 spp.) and dune-endemic species (29 spp.). Of the 34 calcicolous annuals found in the CFR coastal flora, 22 are restricted to dunes.

611

\section{Discussion}

\section{Comparison with other Cape floras}

614 The flora of the Cape is highly distinctive, evident through its recognition as a distinct 615 biogeographic area for nearly two-and-a-half centuries (Bolus, 1886; Goldblatt, 1978; White, 616 1983; Takhtajan, 1986; Linder et al., 2005; Born, Linder \& Desmet, 2007; Colville et al., 2014).

617 The evolution of this flora is intimately tied to the Cape Fold Belt, an ancient mountain range 618 mainly composed of Ordovician-Devonian quarzitic sandstones that weather to shallow, acidic, 619 nutrient-poor, sandy soils. The diversification of several Cape lineages is closely linked to these 620 soils (Hoffmann, Verboom \& Cotterill, 2015; Santen \& Linder, 2019), which have covered 621 extensive areas of the Cape since the sandstones were exhumed following post-Gondwanan, 622 Late-Cretaceous-early-Cenozoic erosion (Partridge, 1998; Tinker, de Wit \& Brown, 2008). Sea-

623 level fluctuations during the Plio-Pleistocene saw, for the first time in the evolutionary history of 624 the CFR, the deposition and exposure of large tracts of calcareous substrata along the coast, 625 providing novel edaphic environments for the colonization and ensuing diversification of the 626 Cape flora (Cowling, Procheş \& Partridge, 2009). How distinct is this coastal flora - the product 627 of the most recent colonization and diversification event in the CFR - from the Cape's typically 628 calcifuge (intolerant of alkaline soils) flora, and what is its contribution to the globally unique 629 plant diversity of this megadiverse region?

630

631 The coastal flora, comprising 1,365 species, accounts for nearly 15\% of flowering-plant species 632 in the CFR (ca. 9,300 spp. in total) (Manning \& Goldblatt, 2012a). While our results showed that 633 most of these species are edaphically widespread, a significant portion (548 spp.) of the coastal 
634 flora is restricted to calcareous substrata. Thus, $6 \%$ of species in the Cape flora are strictly

635 calcicoles with coastal distributions. Both the contemporary ecological conditions and

636 evolutionary history of CFR coastal lowlands differ from that of the inland mountainous regions

637 that gave rise to the ancestral Cape flora. These differences are most pronounced in dune

638 habitats, where a unique selective regime has resulted in regional-scale floras that are typically

639 poorer in species compared to inland floras, albeit marginally (Grobler et al., 2020). Central to

640 this selective regime was the vacillating sea levels of the Pleistocene that led to repeated

641 drowning and exposure of coastal dunes. This instability likely induced high extinction rates in

642 the limited pool of species that were able to colonize the harsh dune environment; here, species

643 must overcome challenges imposed on them by high solar radiation and strong, salt-laden winds

644 throughout the year, the latter of which also carry highly abrasive sand grains and can bury or

645 excavate plants through sand movement (Wilson \& Sykes, 1999; McLachlan \& Brown, 2006;

646 Illenberger \& Burkinshaw, 2008; Maun, 2009). In addition to these factors, plants growing in

647 dunes are affected by the unique soil environment: dune sands are highly alkaline, have a poor

648 water-holding capacity, and characterized by nutritional imbalances induced by the impact of

649 high pH on nutrient uptake (Brady, 1974; Maun, 2009; Pye \& Tsoar, 2009).

650

651 Calcarenite landscapes of CFR coastal lowlands house soils that are chemically and physically

652 similar to those of dune landscapes, although they are generally far shallower and accumulate in

653 fissures and potholes in the underlying calcarenites, thus presenting a challenging edaphic

654 environment for plants. For example, the calcarenite endemics Leucadendron meridianum and

655 Protea obtusifolia exhibit stunted growth (lower stature and smaller canopy volume) and reduced

656 fecundity (fewer cones and fertile seeds) compared to their respective sister taxa, Leucadendron

657 coniferum and Protea susanae, that grow in adjacent, deep colluvial sands on the Agulhas Plain

658 (Mustart \& Cowling, 1993; Mustart, Cowling \& Dunne, 1994). For species that typically grow

659 in deep dune sands, stunted growth appears to be even more pronounced in individuals that have

660 managed to colonize small outcrops of coastal calcarenites: in Erica glumiflora - a dune endemic

661 of the southeastern CFR - typical height in its native dune habitat is ca. 0.6-1.0 m (Schumann,

662 Kirsten \& Oliver, 1992; Oliver, 2012), whereas plants on calcarenite rarely grow more than

$6630.1 \mathrm{~m}$ tall (Figure 10). While calcarenite outcrops do occur near the shore, they are most

664 extensive inland of coastal dunes, and plants associated with this substrate are therefore less 
665 affected by the typically coastal disturbances active in dune environments (e.g., strong winds, 666 salt spray, sand movement). Furthermore, calcarenite landscapes that occur inland of the current 667 coastline have not been directly influenced by sea-level changes since the highstand sequences of 668 the late Pliocene (Partridge \& Maud, 2000; Cowling, Procheş \& Partridge, 2009). This means 669 that, both presently and historically, calcarenite landscapes in the CFR present more stable 670 environments than do coastal dunes, and selection pressures exerted here are likely 671 overwhelmingly edaphic in nature.

672

673 The selective forces active in coastal calcareous landscapes of the Cape have produced a 674 distinctive floral assemblage comprising 226 dune-endemic species and 218 calcarenite-endemic 675 species (each group comprising nearly 3\% of the entire CFR flora), with a further 104 species 676 restricted to coastal calcareous substrata more generally - a high tally given the comparatively 677 short but turbulent past experienced by coastal dune and calcarenite landscapes in the Cape.

679 Not unexpectedly, there are similarities in the floristic composition between the CFR coastal 680 flora and the calcifuge floras associated with montane, acidic soils (McDonald \& Morley, 1988; 681 Taylor, 1996; McDonald, 1999). Note that we include in this acidophile profile floras associated 682 with windblown, acid sands on the lowlands, since these substrata support floras more similar to 683 montane floras than any other soil group in the CFR (Cowling et al., 1988; Thwaites \& Cowling, 684 1988). At the family level, the identity and rank of the three largest plant families - the 685 Asteraceae, Fabaceae and Iridaceae - are the same in both floras, while the Aizoaceae and 686 Scrophulariaceae also occupy similar ranks. There are, however, also striking differences, even 687 at this high taxonomic level: the high numbers of species of Ericaceae, Proteaceae and 688 Restionaceae characteristic of montane floras are not mirrored in the coastal flora, with none of 689 these families featuring in the ten richest families of the latter flora; instead, the Rutaceae and the 690 two graminoid families Cyperaceae and Poaceae feature more prominently in the coastal flora, 691 while the Apiaceae is also more strongly represented. Of the endemic families (Bruniaceae 692 Geissolomataceae, Grubbiaceae, Penaeaceae, Roridulaceae) of the Cape flora (Goldblatt, 1978; 693 Manning \& Goldblatt, 2012a), only the Bruniaceae and Penaeaceae are represented in the coastal 694 flora, though each by only a single species: Brunia laevis (Bruniaceae), occurring on calcarenite 695 and sandstone substrata, and Brachysiphon mundii (Penaeaceae), a range-restricted calcarenite 
696

697

698

699

700

701

702

703

704

705

706

707

708

709

710

711

712

713

714

715

716

717

718

719

720

721

722

723

724

725

726

endemic of the Agulhas Plain Centre. It should be noted that, of the Cape-endemic families, the Bruniaceae (6 genera, 78 spp.) and Penaeaceae ( 7 genera, 23 spp.) are by far the most diverse (all others are monogeneric and mono- or oligotypic) (Manning \& Goldblatt, 2012a), and it is not surprising that these two families have managed to colonize and speciate (in the case of Penaeaceae) on calcareous substrata, even though it is only to a limited extent.

At the generic level, there are again similarities between the CFR coastal flora and montane floras, although they are limited: in both cases, Erica and Aspalathus are the most speciose genera, while Agathosma ranks fourth and third in these floras, respectively. Restio, a highranked genus in montane floras, does not feature in the ten largest genera of the coastal flora, while the same is true for other speciose genera in montane floras, including Phylica, Cliffortia and Oxalis. Genera that feature more prominently in the coastal flora in comparison to montane floras are Ficinia, Hermannia, Indigofera, Crassula and especially the asteraceous genera Senecio and Helichrysum. Thus, while some Cape-centred genera are well-represented in the coastal flora, others are not, instead being replaced by genera that have their centres of diversity outside of the CFR.

The ratio of species per genus (S/G-ratio) in the coastal flora (3.1) is comparable to that of regional floras from the southeastern CFR (mean S/G-ratio $=3.1 \pm 0.55$ ) (Cowling \& Holmes, 1992a), but slightly lower than southwestern floras (3.7 \pm 0.47) (Cowling \& Holmes, 1992a), which tend to be richer in species (Cowling, Holmes \& Rebelo, 1992; Cowling \& Lombard, 2002). The moderate species-to-genus ratio of the coastal flora suggests that there has not been extensive radiation of lineages, although the Rutaceae is one important exception, contributing eight genera and 61 species to the coastal flora (S/G-ratio of 6.8), of which 41 species are endemic to calcareous substrata. Nearly half of the calcicolous Rutaceae belong to Agathosma (19 spp.), a genus which has also diversified extensively on acidic substrata of the CFR (Manning \& Goldblatt, 2012a). While subdued in comparison with floras of the Cape hinterland, there has also been some diversification among other species-rich genera in the coastal flora, for example Ficinia, Helichrysum, Hermannia, Indigofera, Senecio, Phylica, Thamnochortus, and especially the Cape-centred genera Aspalathus, Erica and Muraltia. Unique among tropical genera is Searsia, which has also diversified since colonization of calcareous substrata. 
728 Growth-form composition of the coastal flora mirrors some characteristics of montane floras, for

729

730

731

732

733

734

735

736

737

738

739

740

741

742

743

744

745

746

747

748

749

750

751

752

753

754

755

756

757

example the sparsity of trees, which comprise less than $3 \%$ of species in both cases, and the dominance of shrubs, which constitute about half of all species in both coastal and montane floras (Goldblatt, 1978; Manning \& Goldblatt, 2012a). While shrubs of lower stature, especially dwarf shrubs, are most common in the coastal flora, it is unclear what proportion of montane floras they constitute. Given the selective pressures active in the coastal flora, specifically the persistence of strong winds, it seems likely that a lower stature would impart a selective advantage, and that low growth forms like dwarf shrubs would be more frequent in the coastal flora than in inland floras of the Cape. A peculiarity of the whole Cape flora, particularly among MCEs, is the exceptionally high proportion of geophytic species (Procheş et al., 2006), comprising nearly $20 \%$ of the total flora (Goldblatt, 1978; Manning \& Goldblatt, 2012a) and comprising more than 10\% of regional montane floras (e.g., McDonald, 1999). Our coastal flora has a slightly higher tally (15\% of species are geophytes), while the major families that contribute to this diversity - the Iridaceae, Hyacinthaceae, Orchidaceae, Amaryllidaceae, Asphodelaceae and Oxalidaceae - are the same and maintain similar rankings. Although the number of annual species in the Cape is not low, they are proportionally underrepresented in comparison with other growth forms and with other MCEs, making up only $6.5 \%$ of the Cape flora as a whole (Manning \& Goldblatt, 2012a) and having even lower numbers in montane floras (Taylor, 1978). The proportion of annuals in the coastal flora is higher at $9 \%$, although still relatively low compared to regions of similar climate like California or Chile (Cowling et al., 1996). As in the montane flora of the southern Langeberg (McDonald, 1999), most annual species in the coastal flora belong to the Asteraceae and Scrophulariaceae, and while the Gentianaceae and Lobeliaceae also contribute a large proportion of annuals to the acidophilous Langeberg flora, these families are poorly represented in the coastal annual flora.

Although the bulk of the Cape flora, as described in the above paragraphs, comprises species associated with the geologically ancient Cape Fold Belt, there are subsets of species that are intimately associated with more recently exhumed substrata on the CFR lowlands. Similar to the flora of coastal calcareous substrata, floras of renosterveld - a vegetation type associated with shale geologies and alluvial deposits that give rise to nutrient-rich loamy soils (Boucher \& Moll,

Peer) reviewing PDF | (2021:05:60924:1:1:NEW 7 Jul 2021) 
758 1981) - are a comparatively recent assemblage that emerged during the Mio-Pliocene (Cowling,

759 Procheş \& Partridge, 2009; Hoffmann, Verboom \& Cotterill, 2015). Unfortunately, no

760 comprehensive renosterveld flora exists, but we can gain some insight into the characteristics of

761 renosterveld floras from the limited and disparate site-scale inventories that exist in the literature

762 (Walton, 2006; Kraaij, 2011; Curtis, 2013; Cowan \& Anderson, 2014). In these floras, the

763 Asteraceae, Fabaceae, Poaceae and Iridaceae are typically the dominant families, while the

764 Aizoaceae, Asphodelaceae, Cyperaceae, Hyacinthaceae, Oxalidaceae and Scrophulariaceae are

765 also speciose (Table S4; Kraaij, 2011). Other families that often rank among the twenty most

766 species-rich families include the Amaryllidaceae, Crassulaceae, Geraniaceae, Hypoxidaceae,

767 Polygalaceae and Thymelaeaceae. The most speciose genera are typically Aspalathus, Crassula,

768 Helichrysum, Moraea, Oxalis and Pelargonium, while Hermannia, Ornithogalum and Senecio

769 feature prominently in some floras. Notable is that other geophytic genera, such as Babiana,

770 Drimia, Lachenalia, Romulea, Spiloxene and Trachyandra, commonly harbour several species.

771 Although they are generally not rich in species, genera of tropical affinity, especially Asparagus,

772 Euclea, Olea and Searsia, are common components of renosterveld floras.

773

774 How do renosterveld floras compare with the coastal flora of the CFR? The dominant families -

775 Asteraceae, Fabaceae, and Iridaceae - are the same in renosterveld and the coastal flora, but the

776 graminoid families Cyperaceae and Poaceae rank higher in renosterveld, whereas the Rutaceae -

777 a high-ranking taxon in the coastal flora - forms only a minor component in renosterveld floras.

778 Among genera, typically shrubby lineages like Aspalathus, Helichrysum, Hermannia and

779 Senecio occupy similarly high ranks in the coastal flora and renosterveld floras. Crassula and

780 Pelargonium, as well as geophytic lineages, especially Moraea and Oxalis, rank higher in

781 renosterveld. As renosterveld harbours a disproportionately high diversity of geophytes in the

782 Cape (Cowling, 1990; Procheş et al., 2006), it is not surprising that typically geophytic families

783 (Amaryllidaceae, Hypoxidaceae, Orchidaceae, Oxalidaceae) and genera (Moraea, Ornithogalum,

784 Oxalis, Spiloxene) rank higher among speciose taxa in renosterveld floras compared to the Cape

785 coastal flora. Another conspicuous difference between these floras regards the genera Erica and

786 Agathosma: while they are the most and third-most speciose genera in the coastal flora,

787 respectively, they are typically species-poor in renosterveld floras. Significant features shared

788 between the coastal flora and renosterveld floras are the relatively low rank occupied by the

PeerJ reviewing PDF | (2021:05:60924:1:1:NEW 7 Jul 2021) 
789 Ericaceae, Proteaceae and Restionaceae - families that are species-rich in typical Cape fynbos 790 floras (Goldblatt, 1978; Cowling \& Holmes, 1992a; Manning \& Goldblatt, 2012a) - and the 791 relatively high incidence of tropical lineages, especially prominent at the generic level.

792

793 In an analysis of dominant species in GCFR vegetation types, Bergh et al. (2014) showed that 794 dune fynbos-thicket mosaics ('strandveld' in their terminology) shared floristic links with 795 renosterveld, while limestone fynbos was floristically most similar to fynbos occurring on 796 infertile acid sands. This suggests that the dune component of the Cape coastal flora resembles 797 renosterveld floras more closely, whereas the calcarenite component mirrors the composition of 798 calcifuge fynbos floras. Likely causes of the closer link between dune and renosterveld floras 799 include the higher incidence of non-restioid graminoids (where the Cyperaceae and Poaceae 800 occupy similar ranks as in renosterveld floras) and shrubs allied to subtropical thicket (e.g., 801 Euclea, Olea, Searsia) in dune floras (Cowling et al., 2019).

In terms of growth forms, renosterveld floras are typically dominated by geophytes and low-

804

805 806

807

808 809

810

811

812

813

814

815

816

817

818

819

stature shrubs, followed by forbs (including several annual species) and graminoids (grasses and sedges), while trees and climbing species (lianas and vines) are rare (Cowling, Pierce \& Moll, 1986; Walton, 2006; Kraaij, 2011; Curtis, 2013; Cowan \& Anderson, 2014). Succulents, especially leaf-succulents (Cowling, 1984), are a common component of renosterveld floras, comprising in the order of 10\% of species (Walton, 2006; Kraaij, 2011; Curtis, 2013). This growth-form profile is similar to that of the Cape coastal flora, though geophytes are a much more prominent feature of renosterveld floras, while dwarf shrubs, especially those of Cape affinity, constitute a larger portion of the coastal flora.

Generally, about a third of renosterveld species are endemic to the CFR, especially among shrubs, but geophytes and succulents also exhibit high levels of regional endemism, particularly in renosterveld of the western CFR (Cowling, 1983; Cowling \& Holmes, 1992a). In the fynbosrenosterveld transitional vegetation of the Bontebok National Park, Kraaij (2011) found that 46\% of species are CFR-endemics, while Cowling (1983) found a comparable level of regional endemism in a similar fynbos-renosterveld community in the southeastern Cape. These are modest levels of endemism compared to the coastal flora, in which nearly $60 \%$ of species are

PeerJ reviewing PDF | (2021:05:60924:1:1:NEW 7 Jul 2021) 
820 restricted to the CFR. More comparable is the regional endemism of Cape dune floras, where

821 regional endemism ranges from ca. 30-40\% (Cowling et al., 2019). No information is available

822 on levels of edaphic endemism in renosterveld floras, although it is expected to be modest

823 (Cowling, 1983), other than in habitats associated with locally unusual geologies and soils where

824 edaphic endemism can be pronounced (e.g., Curtis, Stirton \& Muasya, 2013).

825

826 Comparison with other calcareous-substrate floras

827 Information on directly comparable floras - coastal floras associated with calcareous substrata

828 from other Mediterranean-climate ecosystems (MCEs) - is especially sparse, and to our

829 knowledge, our study is the first to present a comprehensive analysis of a coastal flora from one

830 of the world's hyperdiverse MCEs (cf. Rundel et al., 2016). The MCE-zone of central Chile

831 supports well-developed coastal dune systems, of both Holocene and Pleistocene age, but coastal

832 calcarenite formations appear to be a less important feature in this region (Araya-Vergara, 2007).

833 From the limited investigations into coastal dune floras of this region, it is apparent that they

834 share with the Cape coastal flora a dominance by the Asteraceae, Fabaceae and Poaceae, with

835 most species belonging to shrubby lineages (San Martin, Ramírez \& San Martin, 1992).

836 Armesto, Arroyo \& Hinojoa (2007) suggest that several species occurring in Chilean coastal

837 dune floras are dune endemics, but no data exists to support this claim.

838

839

In California, 'unusual' substrata typically comprise serpentine soils, and floras associated with

840 these ultramafic substrata have been the main focus of research into edaphic adaptation and

841 endemism in this region (e.g., Kruckeberg, 1984). The flora of the White Mountains, a range

842 comprising extensive dolomite (calcium-magnesium carbonate rock) outcrops, has been well

843 studied (e.g., Lloyd \& Mitchell, 1973; Rundel, Gibson \& Sharifi, 2008), but it occurs in the

844 Desert and Alpine biomes of eastern California, away from the coast and outside of the

845 Mediterranean-climate zone. Calcareous dunes and calcarenites do occur along the southern

846 Californian coast (Cooper, 1967), but studies into their specific floras are limited, focusing

847 largely on geologically young (Holocene) coastal dune landscapes (e.g., Purer, 1936; Williams \&

848 Potter, 1972; Johnson, 1977; Barbour et al., 1981; Pickart \& Barbour, 2007; Peinado et al., 2011;

849 US Fish \& Wildlife Service, 2016). As in the Cape coastal flora, these Californian floras are

850 typically dominated by members of the Asteraceae, Fabaceae and Poaceae, although the

PeerJ reviewing PDF | (2021:05:60924:1:1:NEW 7 Jul 2021) 
851 Boraginaceae and Amaranthaceae also contribute a substantial proportion of species (Purer,

852 1936; Barbour et al., 1981; Pickart \& Barbour, 2007; US Fish \& Wildlife Service, 2016). A high

853 proportion of these species are associated with the Coastal biome, but as in the CFR, most occur

854 in Mediterranean-type shrublands, namely coastal chaparral (Barbour et al., 1981).

855 Approximately $30-40 \%$ of species in Californian dune floras are restricted to the MCE-zone

856 (Johnson, 1977; Barbour et al., 1981), a moderate level of regional endemism in comparison with

857 the Cape coastal flora, although edaphic endemism in dunes of California, ranging from ca. 20-

858 40\% (Johnson, 1977; Barbour et al., 1981; US Fish \& Wildlife Service, 2016), is comparable.

859

860 Calcareous substrata dominate most of the coastal and inland landscapes of the Mediterranean

861 Basin (Lewin \& Woodward, 2009), and would therefore expect floras associated with

862 Mediterranean coastal substrata to not have been subject to the ecological filter imposed by a

863 strong alkalinity gradient, as is the case in the CFR. Nevertheless, as in the Cape, coastal dune

864 floras of the Mediterranean Basin appear to be a regionally distinct formation, shaped by the

865 strong selective pressures operating in these coastal habitats. Here, the Fabaceae, Asteraceae and

866 Poaceae comprise nearly half of species in local floras, while members of the Amaranthaceae,

867 Caryophyllaceae, Apiaceae and Plambaginaceae are also frequent (Hadjichambis et al., 2004;

868 Korakis \& Gerasimidis, 2006; Ciccarelli, Di Bugno \& Peruzzi, 2014). On limestone formations,

869 floras comprise several species of Fabaceae, Lamiaceae and Rosaceae, most of which are

870 shrubby species associated with Mediterranean-type shrublands (Kruckeberg, 2002).

871 Geographical endemism in limestone floras varies, but several local and regional endemics occur

872 (Kruckeberg, 2002), while in coastal dune floras, about $70 \%$ of species are restricted to the

873 Mediterranean Basin (Hadjichambis et al., 2004; Spanou et al., 2006; Muñoz Vallés, Gallego

874 Fernández \& Dellafiore, 2009; Ciccarelli, Di Bugno \& Peruzzi, 2014; Iliadou et al., 2014.) - a

875 level similar to that found in the Cape coastal flora. Edaphic endemism is believed to be high in

876 Mediterranean calcareous floras (Van Der Maarel \& Van Der Maarel-Versluys, 1996;

877 Kruckeberg, 2002), but data to illustrate this are sparse. Dune endemics comprise ca. 18\% of

878 species in the Israeli coastal dune flora (Barbour et al., 1981; Kutiel, 2001).

879

880 Most akin to the Cape coast in terms of climate, geology and physiography are the dune and

881 calcarenite landscapes of coastal Southwestern Australia, where some data are available on 
882 regional floras of the Swan Coastal Plain (Dixon, 2011; Zemunik et al., 2016) and the South

883 Australian coast (Fleurieu Peninsula to Port Macdonnell) (Oppermann, 1999). Here, the

884 Asteraceae, Fabaceae and Poaceae contribute most species to floras, while the Amaranthaceae,

885 Cyperaceae and Proteaceae are also well represented (Oppermann, 1999; Zemunik et al., 2016) -

886 a pattern similar to the Cape coastal flora. A feature that distinguishes Australian calcareous

887 floras from that of the Cape is the high proportion of Myrtaceae (Dixon, 2011; Zemunik et al.,

888 2016), a family represented in the CFR by a single Gondwanan relict species, Metrosideros

889 angustifolia, but which is absent from calcareous substrata in the region, instead being restricted

890 to riparian habitats of the Cape Fold Belt. Growth-form spectra of Australian coastal floras are

891 also very similar to that of the CFR: they are dominated by shrubby species, the incidence of

892 deciduous and evergreen hemicryptophytes is roughly equal, annuals are subsidiary, and, unusual

893 among MCEs but similar to the Cape, the liana and vine flora is well developed (Oppermann,

894 1999; Zemunik et al., 2016). Levels of geographic endemism in these floras appear to be low

895 compared to the Cape, for example Cowling et al. (1994) found no local endemics on calcareous

896 substrata in 0.1 ha plots at the Barrens in Western Australia, while only $7 \%$ and 14\% of species

897 occurring on calcareous sand and calcarenites, respectively, were regional endemics.

898

899 Morat, Jaffre \& Veillon (1997) provide a description of the flora associated with calcareous

900 substrata on the tropical island archipelago of New Caledonia, recognized globally as a

901 biodiversity hotspot (Mittermeier et al., 2011). Here, these substrata cover ca. 3,800 km² and

902 support various habitats, including tropical rainforest, sclerophyll forest and coastal dunes. While

903 the ecological settings and evolutionary histories of New Caledonia and the Cape are vastly

904 different, the areas covered by calcareous substrata in these regions are similar, thus providing a

905 basis for some rudimentary comparisons between richness and endemism in their floras

906 (Rosenzweig, 1995). The New Caledonian calcareous flora comprises 488 plant species, $40 \%$ of

907 which are endemic to the archipelago (Morat, Jaffre \& Veillon, 1997). Only 87 species are

908 calcicolous (i.e., 18\% edaphic endemism), with most species in the flora (82\%) occurring on

909 various other soil types, including ultramafic soils. Calcicoles comprise less than $3 \%$ of the

910 regional flora (ca. 3,200 spp.) (Morat, 1993), and nearly half (42 spp.) of the calcicolous species

911 are endemic to New Caledonia. The CFR coastal flora is thus far richer in species than the New

912 Caledonian equivalent, with levels of regional and edaphic endemism also being higher in the 
913 Cape. Furthermore, among calcicolous species, regional endemism is much more pronounced in

914 the Cape coastal flora, where calcicoles also comprise double the proportion of the regional flora 915 compared to New Caledonia. The relative paucity of species and endemics on calcareous

916 substrata of New Caledonia is not currently understood, but Morat, Jaffre \& Veillon (1997)

917 suggest that prolonged degradation of calcareous habitats by human activity could partly explain 918 this. As in the Cape, most of New Caledonia's calcareous substrata date from the Quaternary. It

919 is thus likely that the calcicolous flora of New Caledonia emerged in the recent geological past, a

920 result of immigrant species arriving via long-distance dispersal and their offspring diversifying

921 during the Quaternary (Morat, Jaffre \& Veillon, 1997). The relative youthfulness of this flora

922 could therefore also be invoked to partially explain its depauperate nature with respect to the

923 regional flora of New Caledonia, which started to emerge during the late Palaeogene and

924 Neogene (Pillon, 2012), but not in comparison with the CFR coastal flora, which is of a similarly

925 young age (Cowling, Procheş \& Partridge, 2009; Hoffmann, Verboom \& Cotterill, 2015).

926

927 Assembly of the Cape coastal flora

928 The biogeographic affinities of taxa in the CFR coastal flora points to an autochthonous

929 assemblage that has largely been derived from the regional Cape flora; however, there has also

930 been substantial historical input from desert, temperate and tropical floras from outside of the

931 CFR. In this section, we relate the coastal flora to these abutting biogeographic areas that likely

932 acted as the sources of its component species and sketch a brief scenario of its assembly.

933

934 Biogeographic origins

935 Globally, the phylogenetic structuring of regional coastal floras indicate that their component

936 species are typically derived from adjacent, inland floras, rather than being a product of long-

937 distance dispersal from other geographically remote coastal areas (Brunbjerg et al., 2014). This is

938 in accord with our analyses, which show that the Cape coastal flora is overwhelmingly a

939 southern African assemblage, with nearly two-thirds of species belonging to genera with

940 affinities to the subcontinent. Most of these - over a third of the coastal flora - are affiliated with

941 the Greater Cape Floristic Region (GCFR), which includes the CFR as well as the winter-rainfall

942 semi-deserts of the Namaqualand and Hantam-Tanqua-Roggeveld regions (Born, Linder \&

943 Desmet, 2007). The prominence of Cape clades (sensu Linder, 2003) like Agathosma, 
944 Aspalathus, Diosma, Erica, Muraltia and Phylica in the coastal flora, particularly its endemic 945 (calcicolous) component, identifies it as a derivative of the globally distinct Cape flora, but a 946 characteristic element of the typical calcifuge floras of the region that is lacking in the coastal 947 flora is the marked diversity of the Restionaceae and Proteaceae (Goldblatt, 1978; Cowling \& 948 Holmes, 1992a; Manning \& Goldblatt, 2012a). While these two families have given rise to 949 several calcicolous species (16 Restionaceae, 11 Proteaceae), their diversification on calcareous 950 substrata has been disproportionately limited in comparison with these families on acid sands of 951 montane habitats in the CFR (cf. Cowling \& Lamont, 1998; cf. Linder, 2001).

952

953 Other GCFR elements occurring in the Cape coastal flora are affiliated with the winter-rainfall 954 semi-desert regions of western South Africa (cf. Jürgens, 1997; cf. Cowling, Esler \& Rundel, 955 1999; cf. Snijman, 2013) and the Little Karoo (part of the CFR) (cf. Vlok \& Schutte-Vlok, 2015) 956 where the dominant vegetation formation is the Succulent Karoo biome. These overwhelmingly 957 comprise low or succulent dwarf shrubs, best represented in the coastal flora by the Aizoaceae 958 (Carpobrotus, Drosanthemum, Erepsia, Lampranthus) and Asteraceae (Othonna), while several 959 geophytic taxa occurring in the coastal flora, for example Hyacinthaceae (Albuca, Lachenalia, 960 Massonia), Iridaceae (Babiana, Moraea, Romulea) and Oxalidaceae (Oxalis), are also typical 961 components of semi-desert floras in the GCFR.

962

963 Various arid-adapted taxa (families and genera) straddle the divide between the winter-rainfall 964 GCFR and the summer-rainfall semi-deserts (Nama Karoo biome) of southern Africa (Jürgens, 965 1997; Cowling \& Hilton-Taylor, 1999) - typically, these are species of southern-African, but 966 extra-Cape, affinity. In the CFR coastal flora, such species include several succulents, especially among the Aizoaceae (Delosperma, Galenia, Mesembryanthemum, Ruschia), Asphodelaceae (Aloe, Bulbine), Asteraceae (Crassothonna) and Crassulaceae (Crassula, Cotyledon). The Asteraceae further contributes several shrubby, arid-adapted, southern-African lineages to the coastal flora, including Chrysocoma, Felicia, Eriocephalus, Oncosiphon and Pteronia, as do the Fabaceae (Lessertia, Melolobium), Scrophulariaceae (Jamesbrittenia, Selago) and

972 Zygophyllaceae (Roepera). Typical of arid southern African floras, Hermannia (Malvaceae) is 973 among the most diverse shrubby genera in the coastal flora, although nearly half $(10 \mathrm{spp}$.) of the 974 component species are coastal calcicoles (most of these belong to subgenus Hermannia, which is 
975 centred in the CFR) (Verdoorn, 1980). Several annuals - a growth form frequently associated

976 with desert climates (Van Rooyen, 1999; Klak \& Bruyns, 2012) - occurring in the coastal flora

977 belong to higher taxa typical of southern African arid floras, with the Asteraceae (Cotula,

978 Helichrysum, Senecio) and Scrophulariaceae (Zaluzianskya) especially well represented.

979

980

As the coastal habitats of the western CFR were directly linked with those of South Africa's arid

981

982

983

984

985

986

987

988

989

990

991

992

993

994

995

996

997

998

999

1000

1001

1002

1003

1004

1005

west coast throughout the Plio-Pleistocene, there would have been few barriers impeding the southward migration of these winter-rainfall desert elements into the Cape during periods of lower rainfall. Other desert elements affiliated to the interior of southern Africa likely colonized coastal areas of the Cape during periods of similarly arid climates, although these interior source floras did not have a coastal distribution during the Plio-Pleistocene; rather, these elements probably migrated coastward via major river valleys that drain the arid interior, such as the Gouritz, Groot/Gamtoos, Sundays and Fish (Cowling, 1983).

During Pleistocene glacials, coastal forelands of the CFR and Palaeo-Agulhas Plain (PAP) were dominated by fire-prone vegetation, including fynbos, grasslands, renosterveld and alluvial woodlands, while fire-sensitive subtropical thicket was largely restricted to refugial river valleys (Cowling et al., 2020) following a marked regional contraction of this biome during the Neogene (Vlok, Euston-Brown \& Cowling, 2003; Cowling, Procheş \& Vlok, 2005; Potts et al., 2013; Neumann \& Bamford, 2015). The complex microtopography of coastal dunes, which were widespread on the PAP at this time (Cawthra et al., 2020), would have provided fire-sheltered sites in which dune thicket could persist (cf. Cowling et al., 1997a; cf. Cowling \& Potts, 2015), despite the presence of fire in these systems at potentially at higher frequencies than present (Kraaij et al., 2020). Contemporaneously with the establishment of these expansive dune areas, the summer-rainfall zone over southern Africa extended further west into the CFR compared to the contemporary climate zones, particularly during glacials of the mid to late Pleistocene (Engelbrecht et al., 2019), thus allowing these calcareous substrata to act as a corridor for tropical lineages to migrate westward along the coast from the subtropical eastern seaboard of southern Africa into the Cape (Cowling, 1983). Reductions in rainfall and temperature during these glacial periods was remarkably tempered along the coast (Engelbrecht et al., 2019) and would therefore not have posed a major obstacle to the expansion of tropical lineages. It is also

PeerJ reviewing PDF | (2021:05:60924:1:1:NEW 7 Jul 2021) 
1006 important to note that, prior to the establishment of the winter-rainfall regime over southwestern 1007 Africa and the expansion of fire-prone vegetation during the Neogene, subtropical thickets and 1008 forests dominated the area now recognized as the CFR (Neumann \& Bamford, 2015). Thus, 1009 subtropical floras likely have a long history in the region, exemplified by the presence of putative 1010 palaeoendemic genera like Heeria (Anacardiaceae), Hartogiella and Maurocenia (Celastraceae), 1011 Lachnostylis (Phyllanthaceae), Hyaenanche (Picrodendraceae) and Smelophyllum (Sapindaceae)

1012

1013

1014

1015

1016

1017

1018

1019

1020

1021

1022

1023

1024

1025

1026

1027

1028

1029

1030

1031

1032

1033

1034

1035

1036

in the Cape flora (Manning \& Goldblatt, 2012a). Recruitment of tropical lineages into the Cape coastal flora was therefore not necessarily limited to species migrating westward along the coastal margin, but likely involved their incorporation directly from those elements that have persisted in the region since the Palaeogene (Cowling, Procheş \& Vlok, 2005). This is reflected in the prominence of tropical lineages in the Cape coastal flora, both those with Afrotropical and pantropical affinities. Interestingly, none of the ancient Cretaceous lineages characteristic of the southern African thicket flora, for example Encephalartos and the Strelitzia (Cowling, Procheş \& Vlok, 2005), have colonized calcareous substrata in the Cape, and are therefore absent from our flora. However, several basal lineages that evolved during the Eocene, such as the Celastraceae and Sapindaceae (Cowling, Procheş \& Vlok, 2005), are characteristic components of dune thicket communities; in the case of the former, there has even been a marked diversification on coastal calcareous substrata, precipitating the evolution of five CFR-endemic calcicoles (Cassine peragua subsp. barbara, Maurocenia frangula, Maytenus lucida, Maytenus procumbens, Robsonodendron maritimum).

\section{Speciation in the Cape coastal flora}

Most species in the Cape coastal flora have been directly incorporated from adjacent floras associated with older landscapes of the CFR, although a substantial portion have speciated on geologically young, calcareous substrata. A growing body of work (Verboom, Linder \& Stock, 2004; Malgas et al., 2010; Schnitzler et al., 2011; Hoffmann, Verboom \& Cotterill, 2015; Verboom, Stock \& Cramer, 2017; Santen \& Linder, 2019) has provided support for the hypothesis that the edaphic complexity of the CFR has acted as an important catalyst for ecological speciation in the Cape flora by creating a mosaic of divergent selection pressures (Goldblatt, 1978; Cowling, 1987; Linder, 2003). This hypothesis predicts that closely related taxa with sympatric distributions should occur on juxtaposed edaphic substrata, and such patterns 
1037 have been demonstrated for various clades and soil types. In his revision of the genus, Grau 1038 (1973) notes that several Felicia species with broadly sympatric, coastal distributions in the 1039 Cape, including the calcicoles $F$. amelloides, F. amoena subsp. latifolia, and F. echinata, appear 1040 to not be sister taxa and are thus likely the product of ecological speciation. Indeed, it seems that 1041 most calcicolous species in the coastal flora have their sister taxa on non-calcareous substrata, 1042 suggesting that in-situ diversification of dune and calcarenite endemics has generally been 1043 limited, and that ecological speciation has been the major mechanism for diversification in the 1044 Cape coastal flora. This is consistent with the moderate species-to-genus ratio we report for the 1045 coastal flora.

1046

Rourke (1998) describes evolutionary lines, based on changes in morphology, for the two 1048 proteaceous genera Leucospermum and Spatalla, in which species with primitive characters occur in geologically older montane habitats (i.e., sandstone substrata), while more derived, specialized species are associated with geologically young (Plio-Pleistocene) deposits on coastal 1051 lowlands, especially along the Agulhas Plain. In Spatalla, the primitive and derived species form two distinct clades, with section Cyrtostigma comprising the older montane species and section Spatalla comprising the younger, mostly lowland species. While most species of the lowland clade are associated with siliceous substrata, one species, Spatalla ericoides, has evolved on calcarenites, and the general evolutionary pattern demonstrates the influence of Plio-Pleistocene geomorphic evolution along the Cape coast on speciation events and diversity patterns in the CFR.

1058

1059

Is there further evidence of ancient sandstone substrata in the Cape acting as the source of calcicole evolution? In the case of Leucospermum, Rourke (1972) first highlighted the importance of edaphic speciation by showing that various pairs of sister taxa were split between alkaline, calcarenite-derived soils and acidic, sandstone-derived soils. Other examples of this acid-alkaline edaphic divide have also been documented for sister taxa in other Cape lineages, 1064 including Aspalathus (Dahlgren, 1963, 1968), Freesia (Goldblatt, 1982; Manning \& Goldblatt, 2010), Leucadendron (Williams, 1972; Barker et al., 2004), Muraltia (Levyns, 1954; Forest et al., 2007), the Pentaschistis clade of Pentameris (Linder \& Ellis, 1990; Galley \& Linder, 2007), 
1068 Indeed, in cases where information is available, it seems that most calcicoles, especially those of 1069 Cape affinity, have their sister taxa on acid sands. This pattern is consistent with our analysis of 1070 edaphic associations in the coastal flora, which showed that most species with some edaphic 1071 affinity (i.e., excluding species occurring on all soil types) were shared between calcareous 1072 coastal sands, windblown acid sands and sandstone-derived acid sands, suggesting that floras 1073 associated with these siliceous substrata have been the most significant source for colonization of 1074 calcareous substrata in the Cape. None of the species occurring in the coastal flora are shared 1075 exclusively between calcareous substrata and neutral loams - the typical substrate of 1076 renosterveld - suggesting that renosterveld floras have largely been excluded as a source of 1077 colonizing species in the coastal flora.

1078

Achyranthemum, a genus of asteraceous dwarf shrubs recently segregated from Syncarpha (Bergh \& Manning, 2019), provides an interesting example of late-Pliocene diversification (Bergh, Haiden \& Verboom, 2015) resulting in a lineage comprising mostly calcicolous species (4 of 7 spp.). Furthermore, and unique among Cape lineages, the genus is centred in the coastal lowlands of the southeastern CFR. Molecular phylogenetic analysis places the dune endemic Achyranthemum sordescens as sister to the more widespread Achyranthemum striata, a species typically occurring on lowland acid sands, whereas the closest relative of Achyranthemum mucronatum, a calcarenite endemic, is the widespread Achyranthemum paniculatum, which is most abundant on sandstone-derived acid sands (Bergh \& Manning, 2019). While not included in the molecular analysis, morphological characteristics suggest that Achyranthemum argenteum, a dune-endemic species, is closely related to Achyranthemum affine, a species typical of lowland sandstone outcrops. The most restricted species in the genus, Achyranthemum recurvatum, is confined to calcarenites around Algoa Bay and appears to be phylogenetically isolated, being sister to the Achyranthemum-chlorochrysum-mucronatum-paniculatum clade (Bergh \& Manning, 2019). As with most Cape lineages discussed thus far, the diversity patterns within Achyranthemum are most consistent with speciation driven by the ecological opportunities presented by novel edaphic substrata (Bergh, Haiden \& Verboom, 2015), specifically diversification following colonization of coastal calcareous substrata from an inland, acid-sand source. 
1099 While the bulk of ecological speciation in the coastal flora has been among Cape lineages, there 1100 are also examples of tropical lineages colonizing and speciating on calcareous substrata of the 1101 CFR. In these cases, the calcicolous species are typically sister to edaphically widespread species 1102 that occur in inland thickets and forests. Rapanea gilliana, a low shrub endemic to dunes of the 1103 St Francis Bay-Algoa Bay area, is closely related to the tree R. melanophloeos, which occurs in 1104 forests throughout southern Africa (Cowling, 1983). A widespread calcicolous shrub occurring

1105

1106

1107

1108

1109

1110

1111

1112

1113

1114

1115

1116

1117

1118

1119

1120

1121

1122

1123

1124

1125

1126

1127

1128

1129 along the entire CFR coast, Olea exasperata, is a close relative of Olea capensis, typically a tall tree found in forests of southern and tropical Africa (Besnard et al., 2009). Another widespread dune-endemic shrub from the eastern CFR, Maytenus procumbens, is sister to Maytenus undata, a tree species typically growing in inland thicket and forests (Simmons et al., 2008; McKenna et al., 2011), while Maytenus lucida, a dune-endemic shrub restricted to the western CFR, is apparently derived from M. procumbens (Cowling, 1983) - this may be an example of limited calcicolous cladogenesis in this pantropical genus, though further phylogenetic study of this apparent lineage is required to elucidate relationships among its members.

Is there any evidence for in-situ diversification among Cape lineages in the coastal flora? While not supported by any molecular studies, Dahlgren (1988) proposes close affinities between some calcicolous Aspalathus species. Within his 'Adnates' group, for example, Aspalathus pallescens, Aspalathus prostrata and Aspalathus salteri - all calcarenite endemics - are the closest relatives to each other. He also recognizes a 'Calcicolae' group (comprising eight species), centred on the Agulhas Plain and containing three calcarenite-endemic species, Aspalathus aciloba, Aspalathus calcarea and Aspalathus candidula, the latter two species being sympatric and all three closely related. Phylogeographic analysis of the restioid genus Thamnochortus shows that a clade of mostly calcicolous species emerged on the Agulhas Plain; included from the coastal flora are the edaphically widespread Thamnochortus erectus as well as the calcicoles Thamnochortus fraternus, Thamnochortus muirii, Thamnochortus paniculatus, Thamnochortus pluristachyus and Thamnochortus spicigerus (Linder \& Mann, 1998). Another example comes from Metalasia, in which all calcicoles - Metalasia calcicola, Metalasia erectifolia, Metalasia luteola, Metalasia muricata and Metalasia umbelliformis - belong to the same clade that emerged during the PlioPleistocene (Bengtson et al., 2014; Bengtson, Anderberg \& Karis, 2014). Other than the widespread, dune-endemic $M$. muricata, all other species are restricted to calcarenites on the 
1130 Agulhas Plain. Thus, while limited, in-situ diversification has precipitated a few small clades in

1131 the coastal flora, and available information suggests that these are presently concentrated on the

1132 Agulhas Plain of the CFR.

1133

1134

Otholobium provides an interesting example of limited cladogenesis on calcareous substrata

1135

involving both ecological and geographic speciation. Otholobium bracteolatum, a dune-endemic

1136

species from the southern and southwestern CFR, is closely related to the calcarenite endemic

1137

Otholobium sabulosum from the Agulhas Plain, (Stirton \& Muasya, 2017), suggesting that these

1138

two species have evolved due to differential selective pressures in the dune (more dynamic) and

1139

calcarenite (more stable) environment. Otholobium sp. nov. 'algoensis', a dune endemic from the

southeastern CFR, is presumably sister to Otholobium bracteolatum (it was, until recently,

1141

included with this species) (Stirton, 1986), suggesting that these two species may have diverged

1142

and evolved along separate trajectories following the drowning of a previously contiguous

1143 distribution range along the Palaeo-Agulhas Plain. Other examples of such putative geographic speciation include: Thamnochortus insignis and the closely related, undescribed Thamnochortus sp. A (Lubke \& Bredenkamp, 2019), known only from calcarenite outcrops at the mouth of the

Sundays River (Algoa Bay) in the eastern CFR; Pelargonium suburbanum subsp. bipinnatifidum, which occurs on dunes west of Mossel Bay, and P. s. subsp. suburbanum, an endemic of the dunes between St Francis Bay and Algoa Bay.; and the previous example of Maytenus procumbens and Maytenus lucida, occurring in the eastern and western CFR, respectively.

The west-east breaks in distribution along the Cape south coast of the abovementioned species pairs mirrors the distribution of many calcicolous species with disjunct populations, including several members of the Aizoaceae (Carpobrotus acinaciformis, Conicosia pugioniformis subsp. muirii, Mesembryanthemum vanrensburgii), Fabaceae (Indigofera tomentosa, Lotononis glabra, Psoralea repens) and Restionaceae (Elegia fenestrata, Elegia microcarpa, Elegia tectorum, 1156 Restio eliocharis, Restio leptoclados). Some of these disjunctions are well known, for example that of Acmadenia obtusata and Ficinia truncata, species restricted to calcarenites on the Agulhas Plain in the west and inland of Algoa Bay in the east (Taylor \& Morris, 1981); others we report on here for the first time, for example for Cliffortia obcordata and 
1161 in the west and the St Francis Bay-Algoa Bay area in the east (the eastern populations were

1162 recorded during our recent field surveys; see https://www.inaturalist.org/observations/27579755

1163 and https://www.inaturalist.org/observations/20939032). While these south-coast disjunctions

1164 vary somewhat geographically, they are most consistent and pronounced along the Tsitsikamma

1165 coast (Figure 1) - an area largely devoid of calcareous substrata. We would expect similar,

1166 though less marked, disjunctions along other steep, rocky coasts where coastal cliffs have

1167 hampered the accumulation of marine aeolianites, for example around the Cape Peninsula, Cape

1168 Hangklip and the Mossel Bay coast. Phylogenetic investigation of disjunct coastal-endemic

1169 clades and species will shed further light on the timing of sea-level rise and consequent

1170 population fragmentation in the Cape coastal flora.

1171

1172 Unusual substrata provide a selective force for the evolution of neoendemic species, but

1173 alternatively could also provide a refuge from competition for palaeoendemics (Bruchmann \&

1174 Hobohm, 2014). What is the case for the CFR coastal flora? The bulk of species are likely

1175 neoendemics, for example the calcicolous clade of Metalasia emerged during the Pleistocene

1176 (Bengtson et al., 2014; Bengtson, Anderberg \& Karis, 2014), and Gladiolus griseus, a west-coast

1177 dune endemic, diverged from other species in the Gladiolus carinatus species complex during

1178 the Pleistocene, around 0.46 Ma (Rymer et al., 2010). One taxonomically isolated species, which

1179 is largely restricted to coastal dune forests of the southwestern CFR, is the small tree Maurocenia

1180 frangula of the Celastraceae. Its membership to a monospecific genus and its restricted range

1181 suggest that it is a relict of a warmer, wetter climate, and that it likely evolved long before the

1182 rest of the calcicole flora in the Cape. However, recent phylogenetic studies show that

1183 M. frangula is not part of a basally branching lineage and place it as sister to Cassine peragua

1184 (Simmons et al., 2008), suggesting that this species may be a more recent derivative within the

1185 genus Cassine.

1186

1187 Evolutionary adaptations in the Cape coastal flora

1188 What type of adaptations have evolved in coastal-flora endemics in the Cape? Reciprocal

1189 transplant experiments of calcicolous and calcifugous Proteaceae species from the Agulhas Plain

1190 showed higher mortality and reduced growth between substrata than on their native substrata,

1191 indicating a strong physiological adaptation to particular edaphic environments (Newton, 
1192 Cowling \& Lewis, 1991; Mustart \& Cowling, 1993). These calcareous substrata, containing high

1193 levels of $\mathrm{CaCo}_{3}$, typically demand from plants a tolerance to Fe and P deficiencies (Lee, 1999).

1194 Species endemic to calcareous substrata have thus overcome major physiological constraints,

1195 specifically related to nutrient acquisition from highly alkaline soils. In members of the

1196 Proteaceae from the Agulhas Plain, for example, root traits for phosphorous acquisition differ

1197 between calcicolous and calcifugous sister taxa (Shane, Cramer \& Lambers, 2008).

1198

1199 Other adaptations relate to the typical coastal disturbances experienced by plants in the dune

1200 environment (Hesp, 1991), including: salt tolerance to endure salt spray and soil salinity (e.g.,

1201 members of the Amaranthaceae); increased root, shoot and rhizome development to endure sand

1202 burial (e.g., the graminoids Ehrharta villosa, Ficinia dunensis, Thinopyrum distichum, and shrubs Hebenstretia cordata, Morella cordifolia, Psoralea repens); leaf roll (e.g., Moraea australis), leaf indumentum (e.g., Arctotheca populifolia, Gazania rigens), succulence and putative CAM photosynthesis (e.g., members of the Aizoaceae) to endure aridity, high solar radiation and high temperatures; and reduced stature - pronounced in species that develop cushion growth forms (e.g., the shrub Achyranthemum sordescens) - as an adaptation to strong and persistent winds.

Among woody species of tropical origin, there further appears to have been an evolution of shrubby descendants from arborescent ancestors (Cowling, 1983), evident in genera like Cassine, Cussonia, Euclea, Diospyros, Olea, Maytenus, Rapanea, Robsonodendron and Searsia (Figure 11). In certain cases, these calcicolous shrubs can develop as geoxyles, forming extensive networks of below-ground stems that produce aerial shoots along their length. Examples of such species include Cassine peragua subsp. barbara, Diospyros pallens, Euclea racemosa, Olea exasperata, Rapanea gilliana and Searsia laevigata. These geoxylic forms occur most frequently in dune landscapes hosting fire-prone fynbos vegetation (Cowling, 1984), and is likely an adaptation to recurrent fire (Maurin et al., 2014; Lamont, He \& Pausas, 2017).

1221 The CFR coastal flora is rich in species with high levels of geographic and edaphic endemism. 
1223 calcareous substrata, as well as the small and fragmented areas covered by coastal dunes and

1224 calcarenites compared to other more widespread habitats in the CFR (Grobler et al., 2020), how

1225 did this remarkable diversity evolve? The answer likely lies in the glacial physiography of the

1226 Cape's south coast, where large tracts of calcareous substrata were exposed for long periods on

1227 the Palaeo-Agulhas Plain (PAP) (Figure 1) during Pleistocene sea-level lowstands (Cawthra et

1228 al., 2020). At its maximum exposure (e.g., during the Last Glacial Maximum - LGM), the PAP

1229 covered an area nearly equal to that of the contemporary CFR, although, edaphically,

1230 geologically and topographically, it presented a vastly different environment to the Cape of today

1231 (Marean, Cowling \& Franklin, 2020). The subdued topography of this now-submerged plain

1232 provided ample space for the deposition of marine aeolianites: the area of coastal dunes on the

1233 PAP, for example, increased at least 38-fold compared to contemporary dune areas on the

1234 southern Cape coast, providing an additional $12-14,000 \mathrm{~km}^{2}$ of habitat suitable for dune fynbos-

1235 thicket mosaics, while exposed Neogene calcarenites on the PAP, occupying ca. 19-20,000 km²,

1236 increased the available habitat for limestone fynbos at least eight-fold (Cowling et al., 2020).

1237

1238 By invoking age-and-area theory, which explains much of the diversity patterns observed in the

1239 CFR (Cowling et al., 2017; Forest, Colville \& Cowling, 2018; Colville et al., 2020), we argue

1240 that these expansive areas of calcareous habitat, exposed at length during Pleistocene glacials

1241 (Jouzel et al., 2002; Waelbroeck et al., 2002; Fisher et al., 2010), enabled the evolution of a rich

1242 coastal flora in the Cape (Grobler et al., 2020). Age-and-area theory posits that high levels of

1243 biodiversity amass in habitats characterized by sufficiently large areas to support viable biotic

1244 populations and by high environmental stability over evolutionary timescales, synergistically

1245 resulting in reduced extinction rates and increased speciation rates, and ultimately leading to the

1246 accumulation of species from both ancient lineages and more recent radiations (Dynesius \&

1247 Jansson, 2000; Jansson \& Dynesius, 2002; Ricklefs, 2006; Fine, 2015; Schluter, 2016). These

1248 same characteristics would lead to a high incidence of habitat specialists and range-restricted

1249 endemics (Bruchmann \& Hobohm, 2014), as is the case in the CFR coastal flora.

1250

1251 Following the initiation of the Holocene, and during preceding late-Pleistocene interglacials, 1252 warming climates led to rapid increases in sea level (Ramsay \& Cooper, 2002; Murray-Wallace

$1253 \&$ Woodroffe, 2014) and the subsequent drowning of large areas of coastal dunes along the Cape 
1254 coast. This massive shrinkage and fragmentation of dunes relative to their historical (glacial)

1255 extents, which gave rise to their current configuration, would have had a major impact on the 1256 composition of the CFR dune flora and the population sizes of many of its component species. It

1257 is near certain that extinctions would have occurred, either through the gross inundation of

1258 range-restricted species populations, or because of severe genetic bottlenecks due to population

1259 fragmentation following sea-level transgressions. While calcarenite floras on the PAP would

1260 have experienced these same Pleistocene disruptions, the calcarenites exposed on the

1261 contemporary CFR coastal lowlands have not been subjected to sea-level transgression since the

1262 terminal Pliocene (Partridge \& Maud, 2000; Cowling, Procheş \& Partridge, 2009). This probably

1263 rendered these more inland calcareous substrata a refugium for the calcicole flora for the past

12642.5 million years, especially along the Agulhas Plain in the western CFR, which was climatically

1265 buffered during Pleistocene glacials in comparison with calcarenite landscapes along the CFR's

1266 eastern margin (Cowling et al., 1999). The higher environmental stability of the western CFR, in

1267 concert with the relatively large and contiguous areas of calcarenite on the Agulhas Plain, likely

1268 contributed to the concentration of range-restricted calcicoles, especially calcarenite-endemic

1269 species, in this biogeographic centre.

1270

\section{Conclusions}

1272 The Cape coastal flora is a distinctive, species-rich assemblage with high levels of edaphic and 1273 geographic endemism, comprising a significant proportion of all plant species in the CFR and 1274 with its endemic, calcicolous component representing $6 \%$ of the region's plant diversity 1275 compared to other biodiversity hotspots, these are high tallies of unique plant biodiversity on 1276 calcareous substrata. The flora is a distinctly southern African formation, with most species 1277 belonging to Cape lineages (sensu Linder, 2003) and being endemic to the (G)CFR, although a 1278 considerable number of semi-desert and tropical lineages have speciated on calcareous substrata 1279 to produce species endemic to the region. Most of the endemic, calcicolous portion of the coastal 1280 flora emerged during the Plio-Pleistocene via ecological speciation upon colonization of novel 1281 calcareous substrata, with the ancient, calcifugous fynbos floras of montane habitats likely being 1282 the most significant source of lineages to the coastal flora. Of the two calcareous substrata 1283 occurring along the Cape coast, calcarenites appear to have been a more significant sink for Cape 1284 lineages than coastal dunes, suggesting that soil depth may be an important selective factor over 
1285

1286

1287

1288

1289

1290

1291

1292

1293

1294

1295

1296

1297

1298

1299

1300

1301

1302

1303

1304

1305

1306

1307

1308

1309

1310

1311

1312

1313

1314

1315

and above the ecological filter presented by soil $\mathrm{pH}$. Interestingly, the calcareous sands that host the coastal flora are home to few species that also grow in renosterveld, a vegetation type associated with relatively benign, neutral but heavier loamy soils, thus suggesting that soil texture may be an additional edaphic barrier to plant colonization in the Cape flora. These topics present a fertile subject for further research into the physiological and anatomical adaptations of calcicolous plant species in the Cape flora.

\section{Acknowledgements}

We thank Charles H. Stirton, Ross C. Turner and Terry H. Trinder-Smith for sharing their taxonomic knowledge. Nick Helme and Douglas Euston-Brown are thanked for their comments on the edaphic distributions of certain species. Graeme Pienaar, Nick Helme and Tony Rebelo are thanked for sharing their plant photos (shared under Creative Commons licenses via iNaturalist). Our gratitude goes to Ruan van Mazijk and an anonymous reviewer for taking the time to critically read our manuscript; their comments and critique helped to improve the article.

\section{References}

Alonso MÁ, Crespo MB, Martínez-Azorín M, Mucina L. 2021. Taxonomic identity and evolutionary relationships of South African taxa related to the Spergularia media group (Caryophyllaceae). Plant Systematics and Evolution 307:24. DOI: 10.1007/s00606-02101743-6.

Araya-Vergara J. 2007. Ocean Coasts and Continental Shelves. In: Veblen TT, Young KR, Orme AR eds. The Physical Geography of South America. Oxford: Oxford University Press, 249261.

Armesto JJ, Arroyo MTK, Hinojoa LF. 2007. The Mediterranean environment of Central Chile. In: Veblen TT, Young KR, Orme AR eds. The Physical Geography of South America. Oxford: Oxford University Press, 184-199.

Barbour MG, Shmida A, Johnson AF, Holton B. 1981. Comparison of coastal dune scrub in Israel and California: physiognomy, association patterns, species richness, phytogeography. Israel Journal of Plant Sciences 30:181-198. DOI: 10.1080/0021213X.1981.10676919.

Barker NP, Vanderpoorten A, Morton CM, Rourke JP. 2004. Phylogeny, biogeography, and the evolution of life-history traits in Leucadendron (Proteaceae). Molecular Phylogenetics and 
1316

1317

1318

1319

1320

1321

1322

1323

1324

1325

1326

1327

1328

1329

1330

1331

1332

1333

1334

1335

1336

1337

1338

1339

1340

1341

1342

1343

1344

1345

1346

Evolution 33:845-860. DOI: 10.1016/j.ympev.2004.07.007.

Bello A, Stirton CH, Chimphango SBM, Muasya AM. 2017. Taxonomic revision of African Psoralea pinnata species complex (Psoraleeae, Leguminosae). South African Journal of Botany 112:128-179. DOI: 10.1016/j.sajb.2017.05.003.

Bengtson A, Anderberg AA, Karis PO. 2014. Phylogeny and evolution of the South African genus Metalasia (Asteraceae-Gnaphalieae) inferred from molecular and morphological data. Botanical Journal of the Linnean Society 174:173-198. DOI: 10.1111/boj.12114.

Bengtson A, Nylinder S, Karis PO, Anderberg AA. 2014. Evolution and diversification related to rainfall regimes: diversification patterns in the South African genus Metalasia (AsteraceaeGnaphalieae). Journal of Biogeography 42:121-131. DOI: 10.1111/jbi.12390.

Bergh NG, Haiden SA, Verboom GA. 2015. Molecular phylogeny of the 'Cape snow' genus Syncarpha (Asteraceae: Gnaphalieae) reveals a need for generic re-delimitation. South African Journal of Botany 100:219-227. DOI: 10.1016/j.sajb.2015.05.023.

Bergh NG, Manning JC. 2019. Achyranthemum N.G.Bergh, a new genus segregated from Syncarpha DC. (Asteraceae, Gnaphalieae). South African Journal of Botany 125:434-456. DOI: 10.1016/j.sajb.2019.08.015.

Bergh NG, Verboom GA, Rouget M, Cowling RM. 2014. Vegetation types of the Greater Cape Floristic Region. In: Allsop N, Colville JF, Verboom GA eds. Fynbos: Ecology, Evolution, and Conservation of a Megadiverse Region. Oxford: Oxford University Press, 1-25.

Besnard G, Rubio de Casas R, Christin P-A, Vargas P. 2009. Phylogenetics of Olea (Oleaceae) based on plastid and nuclear ribosomal DNA sequences: Tertiary climatic shifts and lineage differentiation times. Annals of Botany 104:143-160. DOI: 10.1093/aob/mcp105.

Bolus H. 1886. Sketch of the flora of South Africa. Cape Town: Richards and Sons. Born J, Linder HP, Desmet P. 2007. The Greater Cape Floristic Region. Journal of Biogeography 34:147-162. DOI: 10.1111/j.1365-2699.2006.01595.x.

Boucher C, Jarman ML. 1977. The vegetation of the Langebaan area, South Africa. Transactions of the Royal Society of South Africa 42:241-272. DOI: 10.1080/00359197709519916.

Boucher C, Moll EJ. 1981. South African Mediterranean shrublands. In: Di Castri F, Goodall DW, Specht RL eds. Mediterranean-Type Shrublands. Amsterdam: Elsevier, 233-248.

Boucher C, Le Roux A. 1993. Dry coastal ecosystems of the South African west coast. In: Van Der Maarel E ed. Ecosystems of the World 2B, Dry Coastal Ecosystems: Africa, America 
1347

1348

1349

1350

1351

1352

1353

1354

1355

1356

1357

1358

1359

1360

1361

1362

1363

1364

1365

1366

1367

1368

1369

1370

1371

1372

1373

1374

1375

1376

1377

and Oceania. Amsterdam: Elsevier, 75-88.

Bradshaw PL, Cowling RM. 2014. Landscapes, rock types and climate of the Greater Cape Floristic Region. In: Allsopp N, Colville JF, Verboom GA eds. Fynbos: Ecology, Evolution, and Conservation of a Megadiverse Region. Oxford: Oxford University Press, 26-46.

Brady NC. 1974. The Nature and Properties of Soils. New York: Macmillan Publishing Co., Inc.

Bredenkamp CL. 2019. A Flora of the Eastern Cape Province. Pretoria: South African National Biodiversity Institute.

Brooke B. 2001. The distribution of carbonate eolianite. Earth-Science Reviews 55:135-164. DOI: 10.1016/S0012-8252(01)00054-X.

Bruchmann I, Hobohm C. 2014. Factors That Create and Increase Endemism. In: Hobohm C ed. Endemism in Vascular Plants. Dordrecht: Springer, 51-68. DOI: 10.1007/978-94-0076913-7_3.

Brunbjerg AK, Cavender-Bares J, Eiserhardt WL, Ejrnaes R, Aarssen LW, Buckley HL, Forey E, Jansen F, Kattge J, Lane C, Lubke RA, Moles AT, Monserrat AL, Peet RK, Roncal J, Wootton L, Svenning J-C. 2014. Multi-scale phylogenetic structure in coastal dune plant communities across the globe. Journal of Plant Ecology 7:101-114. DOI: 10.1093/jpe/rtt069.

Bytebier B, Antonelli A, Bellstedt DU, Linder HP. 2011. Estimating the age of fire in the Cape flora of South Africa from an orchid phylogeny. Proceedings of the Royal Society: Biological Sciences 278:188-95. DOI: 10.1098/rspb.2010.1035.

Carvalho SL, Campbell EE. 2021. The association between bushclumps of Calcrete Bontveld and the adjacent Valley Thicket. South African Journal of Botany 137:406-413. DOI: 10.1016/j.sajb.2020.11.020.

Cawthra HC, Cowling RM, Andò S, Marean CW. 2020. Geological and soil maps of the PalaeoAgulhas Plain for the Last Glacial Maximum. Quaternary Science Reviews 235:105858. DOI: 10.1016/j.quascirev.2019.07.040.

Colville JF, Beale CM, Forest F, Altwegg R, Huntley B, Cowling RM. 2020. Plant richness, turnover, and evolutionary diversity track gradients of stability and ecological opportunity in a megadiversity center. Proceedings of the National Academy of Sciences 117:2002720037. DOI: 10.1073/pnas.1915646117.

Colville JF, Potts AJ, Bradshaw PL, Measey GJ, Snijman D, Picker MD, Procheş Ş, Bowie 
1378

1379

1380

1381

1382

1383

1384

1385

1386

1387

1388

1389

1390

1391

1392

1393

1394

1395

1396

1397

1398

1399

1400

1401

1402

1403

1404

1405

1406

1407

1408

RCK, Manning JC. 2014. Floristic and faunal Cape biochoria: do they exist? In: Allsopp N, Colville JF, Verboom GA eds. Fynbos: Ecology, Evolution, and Conservation of a Megadiverse Region. Oxford: Oxford University Press, 73-92.

Cooper WS. 1967. Coastal Dunes of California. Boulder: Geological Society of America.

Cowan OS, Anderson PML. 2014. The Peninsula Shale Renosterveld of Devil's Peak, Western Cape: A study into the vegetation and seedbank with a view toward potential restoration. South African Journal of Botany 95:135-145. DOI: 10.1016/j.sajb.2014.09.003.

Cowling RM. 1983. Phytochorology and vegetation history in the south-eastern Cape, South Africa. Journal of Biogeography 10:393-419.

Cowling RM. 1984. A syntaxonomic and synecological study in the Humansdorp region of the Fynbos Biome. Bothalia 15:175-227.

Cowling RM. 1987. Fire and its role in coexistence and speciation in Gondwanan shrublands. South African Journal of Science 83:106-112.

Cowling RM. 1990. Diversity components in a species-rich area of the Cape Floristic Region. Journal of Vegetation Science 1:699-710.

Cowling RM. 2001. Endemism. In: Encyclopedia of Biodiversity. Elsevier, 228-236. DOI: 10.1016/B978-0-12-384719-5.00044-7.

Cowling RM, Bradshaw PL, Colville JF, Forest F. 2017. Levyns' Law: Explaining the evolution of a remarkable longitudinal gradient in Cape plant diversity. Transactions of the Royal Society of South Africa 72:184-201. DOI: 10.1080/0035919X.2016.1274277.

Cowling RM, Campbell BM, Mustart P, Mcdonald DJ, Jarman ML, Moll EJ. 1988. Vegetation classification in a floristically complex area: the Agulhas Plain. South African Journal of Botany 54:290-300. DOI: 10.1016/S0254-6299(16)31329-1.

Cowling RM, Cartwright CR, Parkington JE, Allsopp JC. 1999. Fossil wood charcoal assemblages from Elands Bay Cave, South Africa: implications for Late Quaternary vegetation and climates in the winter-rainfall fynbos biome. Journal of Biogeography 26:367-378. DOI: 10.1046/j.1365-2699.1999.00275.x.

Cowling RM, Esler KJ, Rundel PW. 1999. Editorial. Plant Ecology 142:1-2.

Cowling RM, Gallien L, Richardson DM, Ojeda F. 2018. What predicts the richness of seeder and resprouter species in fire-prone Cape fynbos: Rainfall reliability or vegetation density? Austral Ecology. DOI: 10.1111/aec.12606. 
1409 Cowling RM, Heijnis CE. 2001. The identification of Broad Habitat Units as biodiversity entities 1410 for systematic conservation planning in the Cape Floristic Region. South African Journal of Botany 67:15-38. DOI: 10.1016/S0254-6299(15)31087-5.

Cowling RM, Hilton-Taylor C. 1999. Plant biogeography, endemism and diversity. In: Dean WRJ, Milton SJ eds. The Karoo: Ecological Patterns and Processes. Cambridge:

Cambridge University Press, 42-56. DOI: 10.1017/CBO9780511541988.007.

Cowling RM, Holmes PM. 1992a. Flora and vegetation. In: Cowling RM ed. The Ecology of Fynbos: Nutrients, Fire and Diversity. Cape Town: Oxford University Press, 23-61.

Cowling RM, Holmes PM. 1992b. Endemism and speciation in a lowland flora from the Cape Floristic Region. Biological Journal of the Linnean Society 47:367-383. DOI: 10.1111/j.1095-8312.1992.tb00675.x.

Cowling RM, Holmes PM, Rebelo AG. 1992. Plant diversity and endemism. In: The Ecology of Fynbos: Nutrients, Fire and Diversity. Cape Town: Oxford University Press, 62-112.

Cowling RM, Kirkwood D, Midgley JJ, Pierce SM. 1997a. Invasion and persistence of birddispersed, subtropical thicket and forest species in fire-prone fynbos. Journal of Vegetation Science 8:475-488. DOI: 10.2307/3237199.

Cowling RM, Lamont BB. 1998. On the nature of Gondwanan species flocks: Diversity of Proteaceae in Mediterranean South-Western Australia and South Africa. Australian Journal of Botany 46:335-355. DOI: 10.1071/BT97040.

Cowling RM, Logie C, Brady J, Middleton M, Grobler BA. 2019. Taxonomic, biological and geographical traits of species in a coastal dune flora in the southeastern Cape Floristic Region: regional and global comparisons. PeerJ 7:e7336. DOI: 10.7717/peerj.7336.

Cowling RM, Lombard AT. 2002. Heterogeneity, speciation/extinction history and climate: Explaining regional plant diversity patterns in the Cape Floristic Region. Diversity and Distributions 8:163-179.

Cowling RM, Pierce SM. 1988. Secondary succession in coastal dune fynbos: Variation due to site and disturbance. Vegetatio 76:131-139.

Cowling RM, Pierce SM, Moll EJ. 1986. Conservation and utilisation of South Coast renosterveld, an endangered South African vegetation type. Biological Conservation 37:363-377. DOI: 10.1016/0006-3207(86)90078-9.

Cowling RM, Potts AJ. 2015. Climatic, edaphic and fire regime determinants of biome 
1440

1441

1442

1443

1444

1445

1446

1447

1448

1449

1450

1451

1452

1453

1454

1455

1456

1457

1458

1459

1460

1461

1462

1463

1464

1465

1466

1467

1468

1469

1470

boundaries in the eastern Cape Floristic Region. South African Journal of Botany 101:7381. DOI: 10.1016/j.sajb.2015.03.182.

Cowling RM, Potts AJ, Franklin J, Midgley GF, Engelbrecht F, Marean CW. 2020. Describing a drowned Pleistocene ecosystem: Last Glacial Maximum vegetation reconstruction of the Palaeo-Agulhas Plain. Quaternary Science Reviews 235:105866. DOI: 10.1016/j.quascirev.2019.105866.

Cowling RM, Procheş Ş, Partridge TC. 2009. Explaining the uniqueness of the Cape flora: Incorporating geomorphic evolution as a factor for explaining its diversification. Molecular Phylogenetics and Evolution 51:64-74. DOI: 10.1016/j.ympev.2008.05.034.

Cowling RM, Procheş Ş, Vlok JHJ. 2005. On the origin of southern African subtropical thicket vegetation. South African Journal of Botany 71:1-23.

Cowling RM, Richardson DM, Schulze RJ, Hoffman MT, Midgley JJ, Hilton-Taylor C. $1997 \mathrm{~b}$. Species diversity at the regional scale. In: Cowling RM, Richardson DM, Pierce SM eds. Vegetation of Southern Africa. Cambridge: Cambridge University Press, 447-473.

Cowling RM, Rundel PW, Lamont BB, Arroyo MK, Arianoutsou M. 1996. Plant diversity in mediterranean-climate regions. Trends in Ecology and Evolution 11:1996.

Cowling RM, Witkowski ETF, Milewski A V, Newbey KR. 1994. Taxonomic, edaphic and biological aspects of narrow plant endemism on matched sites in mediterranean South Africa and Australia. Journal of Biogeography 21:651-664.

Csardi G, Nepusz T. 2006. The igraph software package for complex network research.

Curtis OE. 2013. Management of Critically Endangered renosterveld fragments in the Overberg, South Africa. University of Cape Town.

Curtis OE, Stirton CH, Muasya a. M. 2013. A conservation and floristic assessment of poorly known species rich quartz-silcrete outcrops within rûens shale renosterveld (Overberg, Western Cape), with taxonomic descriptions of five new species. South African Journal of Botany 87:99-111. DOI: 10.1016/j.sajb.2013.03.017.

Dahlgren R. 1963. Studies on Aspalathus: phytogeographical aspects. Botaniska Notiser 116:431-472.

Dahlgren R. 1968. Distribution and substrate in the South African genus Aspalathus L. Botaniska Notiser 121:505-534.

Dahlgren R. 1988. Volume 16: Fabaceae; Part 3: Papilionoideae; Fascicle 6: Crotalarieae 
1471

1472

1473

1474

1475

1476

1477

1478

1479

1480

1481

1482

1483

1484

1485

1486

1487

1488

1489

1490

1491

1492

1493

1494

1495

1496

1497

1498

1499

1500

1501

(Aspalathus). In: Flora of Southern Africa. Botanical Research Institute, Department of Agriculture and Water Supply,.

Deacon H, Jury M, Ellis F. 1992. Selective regime and time. In: Cowling RM ed. The Ecology of Fynbos: Nutrients, Fire and Diversity. Cape Town: Oxford University Press, 9-22.

Dingle R V., Rogers J. 1972. Pleistocene palaeogeography of the Agulhas Bank. Transactions of the Royal Society of South Africa 40:155-165. DOI: 10.1080/00359197209519415.

Dixon KW. 2011. Coastal Plants: A Guide to the Identification and Restoration of Plants of the Perth Region. Collingwood: CSIRO Publishing.

Dynesius M, Jansson R. 2000. Evolutionary consequences of changes in species' geographical distributions driven by Milankovitch climate oscillations. Proceedings of the National Academy of Sciences 97:9115-9120. DOI: 10.1073/pnas.97.16.9115.

Engelbrecht FA, Marean CW, Cowling RM, Engelbrecht CJ, Neumann FH, Scott L, Nkoana R, O’Neal D, Fisher E, Shook E, Franklin J, Thatcher M, McGregor JL, Van der Merwe J, Dedekind Z, Difford M. 2019. Downscaling Last Glacial Maximum climate over southern Africa. Quaternary Science Reviews 226:105879. DOI: 10.1016/j.quascirev.2019.105879.

Fine PVA. 2015. Ecological and evolutionary drivers of geographic variation in species diversity. Annual Review of Ecology, Evolution, and Systematics 46:369-392. DOI: 10.1146/annurev-ecolsys-112414-054102.

Firke S. 2021. janitor: Simple Tools for Examining and Cleaning Dirty Data.

Fish L, Mashau AC, Moeaha MJ, Nembudani MT. 2015. Identification Guide to the Southern African Grasses: An identification manual with keys, descriptions and distributions. Pretoria: South African National Biodiversity Institute.

Fisher EC, Bar-Matthews M, Jerardino A, Marean CW. 2010. Middle and Late Pleistocene paleoscape modeling along the southern coast of South Africa. Quaternary Science Reviews 29:1382-1398. DOI: 10.1016/j.quascirev.2010.01.015.

Forest F, Colville JF, Cowling RM. 2018. Evolutionary Diversity Patterns in the Cape Flora of South Africa. In: Scherson R, Faith D eds. Phylogenetic Diversity. Cham: Springer International Publishing, 167-187. DOI: 10.1007/978-3-319-93145-6_9.

Forest F, Nänni I, Chase MW, Crane PR, Hawkins JA. 2007. Diversification of a large genus in a continental biodiversity hotspot: Temporal and spatial origin of Muraltia (Polygalaceae) in the Cape of South Africa. Molecular Phylogenetics and Evolution 43:60-74. DOI: 
1502

1503

1504

1505

1506

1507

1508

1509

1510

1511

1512

1513

1514

1515

1516

1517

1518

1519

1520

1521

1522

1523

1524

1525

1526

1527

1528

1529

1530

1531

1532

10.1016/j.ympev.2006.08.017.

Galley C, Linder HP. 2007. The phylogeny of the Pentaschistis clade (Danthonioideae, Poaceae) based on chloroplast DNA, and the evolution and loss of complex characters. Evolution 61:864-884. DOI: 10.1111/j.1558-5646.2007.00067.x.

Goldblatt P. 1978. An analysis of the flora of southern Africa: Its characteristics, relationships, and orgins. Annals of the Missouri Botanical Garden 65:369-436.

Goldblatt P. 1982. Systematics of Freesia Klatt (Iridaceae). Journal of South African Botany 48:39-91.

Goldblatt P, Manning JC. 2007. A Revision of the Southern African Genus Babiana, Iridaceae: Crocoideae. Pretoria and Missouri: South African National Biodiversity Institute and Missouri Botanical Garden.

Goldblatt P, Manning JC. 2010. New taxa of Babiana (Iridaceae: Crocoideae) from coastal Western Cape, South Africa. Bothalia 40:47-53. DOI: 10.4102/abc.v40i1.180.

Goldblatt P, Manning JC. 2011. Systematics and biology of the African genus Ferraria (Iridaceae: Irideae). Bothalia 41:1-40. DOI: 10.4102/abc.v41i1.33.

Grau J. 1973. Revision der Gattung Felicia (Asteraceae). Mitteilungen der Botanischer Staatssammlung München 9:195-705.

Grobler BA, Cawthra HC, Potts AJ, Cowling RM. 2020. Plant diversity of Holocene dune landscapes in the Cape Floristic Region: The legacy of Pleistocene sea-level dynamics. Quaternary Science Reviews 235:106058. DOI: 10.1016/j.quascirev.2019.106058.

He T, Lamont BB, Manning J. 2016. A Cretaceous origin for fire adaptations in the Cape flora. Scientific Reports 6:34880. DOI: 10.1038/srep34880.

Hesp PA. 1991. Ecological processes and plant adaptations on coastal dunes. Journal of Arid Environments 21:165-191. DOI: 10.1016/S0140-1963(18)30681-5.

Hoffmann V, Verboom GA, Cotterill FPD. 2015. Dated plant phylogenies resolve Neogene climate and landscape evolution in the Cape Floristic Region. PLoS ONE 10:e137847. DOI: 10.1371 journal.pone.0137847.

Illenberger WK, Burkinshaw JR. 2008. Coastal dunes and dunefields. In: Lewis CA ed. The Geomorphology of the Eastern Cape. Grahamstown: Grocott and Shetty, 71-86. van Jaarsveld E, Koutnik D. 2004. Cotyledon and Tylecodon. Hatfield: Umdaus Press. Jansson R, Dynesius M. 2002. The fate of clades in a world of recurrent climatic change: 
1533

1534

1535

1536

1537

1538

1539

1540

1541

1542

1543

1544

1545

1546

1547

1548

1549

1550

1551

1552

1553

1554

1555

1556

1557

1558

1559

1560

1561

1562

1563

Milankovitch oscillations and evolution. Annual Review of Ecology and Systematics 33:741-777. DOI: 10.1146/annurev.ecolsys.33.010802.150520.

Johnson AF. 1977. A survey of the strand and dune vegetation along the Pacific and southern Gulf coasts of Baja California, Mexico. Journal of Biogeography 4:83. DOI: $10.2307 / 3038131$.

Jouzel J, Hoffmann G, Parrenin F, Waelbroeck C. 2002. Atmospheric oxygen 18 and sea-level changes. Quaternary Science Reviews 21:307-314. DOI: 10.1016/S0277-3791(01)00106-8.

Jürgens N. 1997. Floristic biodiversity and history of African arid regions. Biodiversity and Conservation 6:495-514. DOI: 10.1023/A:1018325026863.

Klak C, Bruyns P V. 2012. Phylogeny of the Dorotheantheae (Aizoaceae), a tribe of succulent annuals. Taxon 61:293-307. DOI: 10.1002/tax.612002.

Köcke A V., von Mering S, Mucina L, Kadereit JW. 2010. Revision of the Mediterranean and southern African Triglochin bulbosa complex (Juncaginaceae). Edinburgh Journal of Botany 67:353-398. DOI: 10.1017/S0960428610000041.

Kraaij T. 2011. The flora of the Bontebok National Park in regional perspective. South African Journal of Botany 77:455-473. DOI: 10.1016/j.sajb.2010.09.013.

Kraaij T, Engelbrecht F, Franklin J, Cowling RM. 2020. A fiery past: A comparison of glacial and contemporary fire regimes on the Palaeo-Agulhas Plain, Cape Floristic Region. Quaternary Science Reviews 235:106059. DOI: 10.1016/j.quascirev.2019.106059.

Kraaij T, Van Wilgen BW. 2014. Drivers, ecology, and management of fire in fynbos. In: Allsopp N, Colville JF, Verboom GA eds. Fynbos: Ecology, Evolution, and Conservation of a Megadiverse Region. Oxford: Oxford University Press, 47-72.

Kruckeberg AR. 1984. California Serpentines: Flora, Vegetation, Geology, Soils, and Management Problems. Berkeley and Los Angeles: University of California Press.

Kruckeberg AR. 1986. An essay: The stimulus of unusual geologies for plant speciation. Systematic Botany 11:455. DOI: 10.2307/2419082.

Kruckeberg AR. 2002. Geology and Plant Life: The Effects of Landforms and Rock Types on Plants. Seattle: University of Washington Press.

Kruckeberg AR, Rabinowitz D. 1985. Biological aspects of endemism in higher plants. Annual Review of Ecology and Systematics 16:447-479.

Lamont BB, He T, Pausas JG. 2017. African geoxyles evolved in response to fire; frost came 
1564

1565

1566

1567

1568

1569

1570

1571

1572

1573

1574

1575

1576

1577

1578

1579

1580

1581

1582

1583

1584

1585

1586

1587

1588

1589

1590

1591

1592

1593

1594

later. Evolutionary Ecology 31:603-617. DOI: 10.1007/s10682-017-9905-4.

Lee JA. 1999. The calcicole-calcifuge problem revisited. In: Callow JA ed. Advances in Botanical Research. San Diego and London: Academic Press, 1-30.

Levyns M. 1954. The genus Muraltia. Journal of South African Botany 2 (Suppl.):1-247.

Lewin J, Woodward J. 2009. Karst Geomorphology and Environmental Change. In: Woodward JC ed. Physical Geography of the Mediterranean. Oxford: Oxford University Press, 287 317.

Linder HP. 1990. A morphological study on the Thamnochortus erectus complex (Restionaceae). South African Journal of Botany 56:443-449. DOI: 10.1016/S0254-6299(16)31040-7.

Linder HP. 2001. On areas of endemism, with an example from the African Restionaceae. Systematic Biology 50:892-912. DOI: 10.1080/106351501753462867.

Linder HP. 2003. The radiation of the Cape flora, southern Africa. Biological Reviews 78:597638. DOI: $10.1017 /$ S1464793103006171.

Linder HP, Ellis RP. 1990. A revision of Pentaschistis (Arundineae: Poaceae). Contributions from the Bolus Herbarium 12:1-124.

Linder HP, Lovett J, Mutke JM, Barthlott W, Jürgens N, Rebelo T, Küper W. 2005. A numerical re-evaluation of the sub-Saharan phytochoria of mainland Africa. Biologiske Skrifter 55:229-252.

Linder HP, Mann DM. 1998. The phylogeny and biogeography of Thamnochortus (Restionaceae). Botanical Journal of the Linnean Society 128:319-357. DOI: 10.1006/bojl.1998.0208.

Lloyd RM, Mitchell RS. 1973. A Flora of the White Mountains, California and Nevada. Berkeley, Los Angeles, London: University of California Press.

Lubke RA, Avis AM, Steinke TD, Boucher C. 1997. Coastal Vegetation. In: Cowling RM, Richardson DM, Pierce SM eds. Vegetation of Southern Africa. Cambridge: Cambridge University Press, 300-312.

Lubke RA, Bredenkamp CL. 2019. Restionaceae. In: Bredenkamp CL ed. A Flora of the Eastern Cape Province, Vol. 3. Pretoria: South African National Biodiversity Institute, 2107-2129.

Malgas RR, Potts AJ, Oettlé NM, Koelle B, Todd SW, Verboom GA, Hoffman MT. 2010. Distribution, quantitative morphological variation and preliminary molecular analysis of different growth forms of wild rooibos (Aspalathus linearis) in the northern Cederberg and 
1595

1596

1597

1598

1599

1600

1601

1602

1603

1604

1605

1606

1607

1608

1609

1610

1611

1612

1613

1614

1615

1616

1617

1618

1619

1620

1621

1622

1623

1624

1625

on the Bokkeveld Plateau. South African Journal of Botany 76:72-81. DOI: 10.1016/j.sajb.2009.07.004.

Manning JC. 2019. The genus Massonia Thunb. ex Houtt. (Hyacinthaceae: Scilloideae) in the Core Cape Floristic Region. South African Journal of Botany 121:329-354. DOI: 10.1016/j.sajb.2018.11.015.

Manning JC, Goldblatt P. 2010. Botany and Horticulture of the Genus Freesia (Iridaceae). Pretoria: South African National Biodiversity Institute.

Manning JC, Goldblatt P (eds.). 2012a. Plants of the Greater Cape Floristic Region, Vol. 1: the Core Cape Flora. Pretoria: South African National Biodiversity Institute.

Manning JC, Goldblatt P. 2012b. A taxonomic revision of the southern African native and naturalized species of Silene L. (Caryophyllaceae). Bothalia 42:147-186. DOI: 10.4102/abc.v42i2.14.

Manning JC, Goldblatt P, Forest F. 2009. A revision of Fumariaceae (Fumarioideae) in southern Africa, including naturalized taxa. Bothalia 39:47-65. DOI: 10.4102/abc.v39i1.229.

Marean CW, Cowling RM, Franklin J. 2020. The Palaeo-Agulhas Plain: Temporal and spatial variation in an extraordinary extinct ecosystem of the Pleistocene of the Cape Floristic Region. Quaternary Science Reviews 235:106161. DOI: 10.1016/j.quascirev.2019.106161.

Maun MA. 2009. The Biology of Coastal Sand Dunes. Oxford: Oxford University Press.

Maurin O, Davies TJ, Burrows JE, Daru BH, Yessoufou K, Muasya AM, Bank M, Bond WJ. 2014. Savanna fire and the origins of the 'underground forests' of Africa. New Phytologist 204:201-214. DOI: 10.1111/nph.12936.

McDonald DJ. 1999. Montane flora of the southern Langeberg, South Africa: a checklist of the flowering plants and ferns. Bothalia 29:119-137. DOI: 10.4102/abc.v29i1.584.

McDonald DJ, Morley M. 1988. A checklist of the flowering plants and ferns of Swartboschkloof, Jonkershoek, Cape Province. Bothalia 18:261-270. DOI: 10.4102/abc.v18i2.1049.

McKenna MJ, Simmons MP, Bacon CD, Lombardi JA. 2011. Delimitation of the Segregate Genera of Maytenus s. 1. (Celastraceae) Based on Morphological and Molecular Characters. Systematic Botany 36:922-932. DOI: 10.1600/036364411X604930.

McLachlan A, Brown AC. 2006. The Ecology of Sandy Shores. Burlington: Academic Press Limited. 
1626 Mergili M, Privett S. 2008. Vegetation and vegetation-environment relationships at Grootbos 1627 Nature Reserve, Western Cape, South Africa. Bothalia 38:89-102.

1628 Mittermeier RA, Turner WR, Larsen FW, Brooks TM, Gascon C. 2011. Global Biodiversity Conservation: The Critical Role of Hotspots. In: Biodiversity Hotspots. Berlin, Heidelberg: Springer Berlin Heidelberg, 3-22. DOI: 10.1007/978-3-642-20992-5_1.

Mooney HA, Troughton JH, Berry JA. 1977. Carbon isotope ratio measurements of succulent plants in southern Africa. Oecologia 30:295-305. DOI: 10.1007/BF00399762.

Morat P. 1993. Our knowledge of the flora of New Caledonia: Endemism and diversity in 1634 relation to vegetation types and substrates. Biodiversity Letters 1:72. DOI: $10.2307 / 2999750$.

Morat P, Jaffre T, Veillon J-M. 1997. The flora of New Caledonia's calcareous substrates. Adansonia 23:109-127.

Murray-Wallace C V., Woodroffe CD. 2014. Quaternary Sea-Level Changes. Cambridge: Cambridge University Press. DOI: 10.1017/CBO9781139024440.

Mustart PJ, Cowling RM. 1993. The role of regeneration stages in the distribution of edaphically restricted fynbos Proteaceae. Ecology 74:1490-1499. DOI: 10.2307/1940077.

Mustart PJ, Cowling RM, Dunne TT. 1994. Reproductive traits of two closely related speciespairs on adjacent, different soil types in South African Fynbos. Vegetatio 111:161-171. DOI: 10.1007/BF00040335.

Nordenstam B. 1968. The genus Euryops. Part I. Taxonomy. Opera Botanica 20:1-409.

Nordenstam B. 1969. Phytogeography of the genus Euryops (Compositae): A contribution to the phytogeography of southern Africa. Opera Botanica 23:1-77.

Neumann FH, Bamford MK. 2015. Shaping of modern southern African biomes: Neogene vegetation and climate changes. Transactions of the Royal Society of South Africa 70:195212. DOI: 10.1080/0035919X.2015.1072859.

Newton IP, Cowling RM, Lewis OAM. 1991. Growth of calcicole and calcifuge Agulhas Plain Proteaceae on contrasting soil types, under glasshouse conditions. South African Journal of Botany 57:319-324. DOI: 10.1016/S0254-6299(16)30909-7.

Nkonki T. 2013. A Taxonomic Study of the Genus Lessertia DC. (Fabaceae, Galegeae). University of Johannesburg.

Oliver EGH. 2012. Ericaceae. In: Manning J, Goldblatt P eds. Plants of the Greater Cape 
1657

1658

1659

1660

1661

1662

1663

1664

1665

1666

1667

1668

1669

1670

1671

1672

1673

1674

1675

1676

1677

1678

1679

1680

1681

1682

1683

1684

1685

1686

1687

Floristic Region, Vol. 1: the Core Cape Flora. Pretoria: South African National Biodiversity Institute,.

Olivier MC. 1983. An annotated systematic checklist of the Angiospermae of the Cape Receife Nature Reserve, Port Elizabeth. Journal of South African Botany 49:161-174.

Oppermann A. 1999. A Biological Survey of the South Australian Coastal Dune and Clifftop Vegetation. South Australia.

Partridge TC. 1998. Of diamonds, dinosaurs and diastrophism; 150 million years of landscape evolution in southern Africa. South African Journal of Geology 101:167-184.

Partridge TC, Maud RR. 2000. Macro-scale geomorphic evolution of southern Africa. In: Partridge TC, Maud RR eds. The Cenozoic of southern Africa. New York: Oxford University Press, 3-18.

Pausas JG, Pratt RB, Keeley JE, Jacobsen AL, Ramirez AR, Vilagrosa A, Paula S, Kaneakua-Pia IN, Davis SD. 2016. Towards understanding resprouting at the global scale. New Phytologist 209:945-954. DOI: 10.1111/nph.13644.

Pedersen TL. 2020. patchwork: The Composer of Plots.

Pedersen TL. 2021. ggraph: An Implementation of Grammar of Graphics for Graphs and Networks.

Peinado M, Ocaña-Peinado FM, Aguirre JL, Delgadillo J, Macías MÁ, Díaz-Santiago G. 2011. A phytosociological and phytogeographical survey of the coastal vegetation of western North America: beach and dune vegetation from Baja California to Alaska. Applied Vegetation Science 14:464-484. DOI: 10.1111/j.1654-109X.2011.01134.X.

Pickart AJ, Barbour MG. 2007. Beach and Dune. In: Barbour MG, Keeler-Wolf T, Schoenherr AA eds. Terrestrial Vegetation of California. Berkeley, Los Angeles, London: University of California Press, 155-179.

Pillon Y. 2012. Time and tempo of diversification in the flora of New Caledonia. Botanical Journal of the Linnean Society 170:288-298. DOI: 10.1111/j.1095-8339.2012.01274.x.

Potts AJ, Hedderson TA, Vlok JHJ, Cowling RM. 2013. Pleistocene range dynamics in the eastern Greater Cape Floristic Region: A case study of the Little Karoo endemic Berkheya cuneata (Asteraceae). South African Journal of Botany 88:401-413. DOI: 10.1016/j.sajb.2013.08.009.

Procheş Ş, Cowling RM, Goldblatt P, Manning JC, Snijman DA. 2006. An overview of the Cape 
1688

1689

1690

1691

1692

1693

1694

1695

1696

1697

1698

1699

1700

1701

1702

1703

1704

1705

1706

1707

1708

1709

1710

1711

1712

1713

1714

1715

1716

1717

1718

geophytes. Biological Journal of the Linnean Society 87:27-43. DOI: 10.1111/j.10958312.2006.00557.x.

Puff C. 1986. A Biosystematic Study of the African and Madagascan Rubiaceae-Anthospermeae. Wien/NewYork: Springer.

Purer EA. 1936. Plants of Silver Strand Beach State Park, San Diego County, California: A Visitor's Handbook. San Diego: Self-published.

Pye K, Tsoar H. 2009. Aeolian Sand and Sand Dunes. Berlin and Heidelberg: Springer.

R Core Team. 2021. R: A language and environment for statistical computing.

Rajakaruna N. 2018. Lessons on evolution from the study of edaphic specialization. Botanical Review 84:39-78. DOI: 10.1007/s12229-017-9193-2.

Ramsay PJ, Cooper JAG. 2002. Late Quaternary sea-level change in South Africa. Quaternary Research 57:82-90. DOI: 10.1006/qres.2001.2290.

Rebelo AG, Boucher C, Helme NA, Mucina L, Rutherford MC. 2006. Fynbos Biome. In: Mucina L, Rutherford MC eds. The Vegetation of South Africa, Lesotho and Swaziland. Pretoria: South African National Biodiversity Institute, 53-219.

Rebelo AG, Cowling RM, Campbell BM, Meadows M. 1991. Plant communities of the Riversdale Plain. South African Journal of Botany 57:10-28. DOI: 10.1016/S02546299(16)30982-6.

Rebelo AG, Siegfried WR. 1990. Protection of Fynbos vegetation: Ideal and real-world options. Biological Conservation 54:15-31. DOI: 10.1016/0006-3207(90)90039-R.

Ricklefs RE. 2006. Evolutionary diversification and the origin of the diversity-environment relationship. Ecology 87 (Suppl.:S3-S13.

Roberts DL, Botha GA, Maud RR, Pether J. 2006. Coastal Cenozoic deposits. In: Johnson MR, Anhaeusser CR, Thomas RJ eds. The Geology of South Africa. Johannesburg/Pretoria: Geological Society of South Africa/Council for Geoscience, 605-628.

Roberts D, Cawthra H, Musekiwa C. 2014. Dynamics of late Cenozoic aeolian deposition along the South African coast: a record of evolving climate and ecosystems. Geological Society, London, Special Publications 388:353-387. DOI: 10.1144/SP388.11.

Van Rooyen MW. 1999. Functional aspects of short-lived plants. In: Dean WRJ, Milton SJ eds. The Karoo. Cambridge: Cambridge University Press, 107-122. DOI:

10.1017/CBO9780511541988.011. 
1719 Rosenzweig ML. 1995. Species Diversity in Space and Time. New York: Cambridge University 1720 Press.

1721 Rourke JP. 1972. Taxonomic studies on Leucospermum R.Br. Journal of South African Botany 8 1722 (Suppl.):1-194.

1723 Rourke JP. 1980. The Proteas of Southern Africa. Cape Town: Purnell.

1724 Rourke JP. 1998. A review of the systematics and phylogeny of the African Proteaceae.

1725 Australian Systematic Botany 11:267. DOI: 10.1071/SB97027.

1726 Rundel PW, Arroyo MTK, Cowling RM, Keeley JE, Lamont BB, Pausas JG, Vargas P. 2018.

1727 Fire and plant diversification in Mediterranean-climate regions. Frontiers in Plant Science

1728 9:851. DOI: 10.3389/fpls.2018.00851.

1729 Rundel PW, Arroyo MTK, Cowling RM, Keeley JE, Lamont BB, Vargas P. 2016. Mediterranean biomes: Evolution of their vegetation, floras, and climate. Annual Review of Ecology, Evolution, and Systematics 47:383-407. DOI: 10.1146/annurev-ecolsys-121415-032330.

Rundel PW, Gibson AC, Sharifi MR. 2008. The alpine flora of the White Mountains, California. Madroño 55:202-215. DOI: 10.3120/0024-9637-55.3.202.

Rymer PD, Manning JC, Goldblatt P, Powell MP, Savolainen V. 2010. Evidence of recent and continuous speciation in a biodiversity hotspot: A population genetic approach in southern African gladioli (Gladiolus; Iridaceae). Molecular Ecology 19:4765-4782. DOI: 10.1111/j.1365-294X.2010.04794.x.

San Martin J, Ramírez C, San Martin C. 1992. La flora de las dunas chilenas y sus adaptaciones morfológicas. Bosque 13:29-39.

Santen M Van, Linder HP. 2019. The assembly of the Cape flora is consistent with an edaphic rather than climatic filter. Molecular Phylogenetics and Evolution:106645. DOI: 10.1016/j.ympev.2019.106645.

Schluter D. 2016. Speciation, ecological opportunity, and latitude. The American Naturalist 187:1-18. DOI: 10.1086/684193.

Schnitzler J, Barraclough TG, Boatwright JS, Goldblatt P, Manning JC, Powell MP, Rebelo T, Savolainen V. 2011. Causes of plant diversification in the Cape biodiversity hotspot of South Africa. Systematic Biology 60:343-357. DOI: 10.1093/sysbio/syr006.

Schubert MTR, Wyk B-E. 1997. A revision of Centella series Capenses (Apiaceae). Nordic Journal of Botany 17:301-314. DOI: 10.1111/j.1756-1051.1997.tb00318.x. 
1750 Schulze RE. 2008. South African Atlas of Climatology and Agrohydrology. WRC Report

1751 1489/1/06. Pretoria.

1752 Schumann D, Kirsten G, Oliver EGH. 1992. Ericas of South Africa. Cape Town: Fernwood 1753 Press.

1754 Shane MW, Cramer MD, Lambers H. 2008. Root of edaphically controlled Proteaceae turnover 1755 on the Agulhas Plain, South Africa: phosphate uptake regulation and growth. Plant, Cell \& 1756 Environment 31:1825-1833. DOI: 10.1111/j.1365-3040.2008.01889.x.

1757 Simmons MP, Cappa JJ, Archer RH, Ford AJ, Eichstedt D, Clevinger CC. 2008. Phylogeny of 1758 the Celastreae (Celastraceae) and the relationships of Catha edulis (qat) inferred from 1759 morphological characters and nuclear and plastid genes. Molecular Phylogenetics and 1760 Evolution 48:745-757. DOI: 10.1016/j.ympev.2008.04.039.

Snijman DA (ed.). 2013. Plants of the Greater Cape Floristic Region, Vol. 2: the Extra Cape Flora. Pretoria: South African National Biodiversity Institute.

Stirton C. 1986. Notes on the genus Otholobium (Psoraleeae, Fabaceae). South African Journal of Botany 52:1-6. DOI: 10.1016/S0254-6299(16)31592-7.

Stirton CH, Muasya AM. 2017. Ten new species and a new record for the genus Otholobium (Psoraleeae, Leguminosae) from South Africa. Kew Bulletin 72:50. DOI: 10.1007/s12225017-9722-5.

Strydom T, Kraaij T, Difford M, Cowling RM. 2020. Fire severity effects on resprouting of subtropical dune thicket of the Cape Floristic Region. PeerJ 8:e9240. DOI: 10.7717/peerj.9240.

Takhtajan A. 1986. Floristic Regions of the World. Berkley: University of California Press.

Taylor HC. 1978. Capensis. In: Werger MJA ed. Biogeography and Ecology of Southern Africa. The Hague: Dr J. Junk bv Publishers, 171-230.

Taylor HC. 1996. Cederberg vegetation and flora. Strelitzia 3:1-76.

Taylor HC, Boucher C. 1993. Dry coastal ecosystems of the South African south coast. In: Van Der Maarel E ed. Ecosystems of the World 2B, Dry Coastal Ecosystems: Africa, America and Oceania. Amsterdam: Elsevier, 89-107.

Taylor HC, Morris JW. 1981. A brief account of coast vegetation near Port Elizabeth. Bothalia 13:519-525.

Thwaites RN, Cowling RM. 1988. Soil-vegetation relationships on the Agulhas Plain, South 
1781

1782

1783

1784

1785

1786

1787

1788

1789

1790

1791

1792

1793

1794

1795

1796

1797

1798

1799

1800

1801

1802

1803

1804

1805

1806

1807

1808

1809

1810

1811

Africa. Catena 15:333-345. DOI: 10.1016/0341-8162(88)90055-0.

Tinker J, de Wit M, Brown R. 2008. Mesozoic exhumation of the southern Cape, South Africa, quantified using apatite fission track thermochronology. Tectonophysics 455:77-93. DOI: 10.1016/j.tecto.2007.10.009.

Tinley KL. 1985. Coastal Dunes of South Africa.

US Fish \& Wildlife Service. 2016. Final Comprehensive Conservation Plan and Environmental Assessment: Guadalupe-Nipomo Dunes National Wildlife Refuge.

Verboom GA, Linder HP, Forest F, Hoffmann V, Bergh NG, Cowling RM, Allsopp N, Colville JF. 2014. Cenozoic assembly of the Greater Cape flora. In: Allsopp N, Colville JF, Verboom GA eds. Fynbos: Ecology, Evolution, and Conservation of a Megadiverse Region. Oxford: Oxford University Press, 93-118.

Verboom GA, Linder HP, Stock WD. 2004. Testing the adaptive nature of radiation: growth form and life history divergence in the African grass genus Ehrharta (Poaceae: Ehrhartoideae). American Journal of Botany 91:1364-1370. DOI: 10.3732/ajb.91.9.1364.

Verboom GA, Stock WD, Cramer MD. 2017. Specialization to extremely low-nutrient soils limits the nutritional adaptability of plant lineages. The American Naturalist 189:684-699. DOI: $10.1086 / 691449$.

Verdoorn IC. 1980. Revision of Hermannia subgenus Hermannia in southern Africa. Bothalia 13:1-63. DOI: 10.4102/abc.v13i1/2.1291.

Vlok JHJ, Euston-Brown DIW, Cowling RM. 2003. Acocks' Valley Bushveld 50 years on: New perspectives on the delimitation, characterisation and origin of subtropical thicket vegetation. South African Journal of Botany 69:27-51.

Vlok JHJ, Schutte-Vlok AL. 2015. Plants of the Klein Karoo. Hatfield: Umdaus Press. Waelbroeck C, Labeyrie L, Michel E, Duplessy JC, McManus JF, Lambeck K, Balbon E, Labracherie M. 2002. Sea-level and deep water temperature changes derived from benthic foraminifera isotopic records. Quaternary Science Reviews 21:295-305. DOI: 10.1016/S0277-3791(01)00101-9.

Walton BA. 2006. Vegetation patterns and dynamics of renosterveld at Agter-Groeneberg Conservancy, Western Cape, South Africa. Stellenbosch University.

White F. 1983. The Vegetation of Africa. A Descriptive Memoir to Accompany the UNESCO/AETFAT/UNSO Vegetation Map of Africa. Paris: UNESCO. 
1812 Whitehouse CM. 2002. Systematics of the genus Cliffortia L. (Rosaceae). University of Cape 1813 Town.

1814 Wickham H, Averick M, Bryan J, Chang W, McGowan L, François R, Grolemund G, Hayes A, 1815 Henry L, Hester J, Kuhn M, Pedersen T, Miller E, Bache S, Müller K, Ooms J, Robinson D, 1816 Seidel D, Spinu V, Takahashi K, Vaughan D, Wilke C, Woo K, Yutani H. 2019. Welcome

\section{Wilkins D, Rudis B. 2021. treemapify: Draw Treemaps in "ggplot2."}

Williams IJM. 1972. A revision of the genus Leucadendron (Proteaceae). Contributions from the Bolus Herbarium 3:1-425.

Williams WT, Potter JR. 1972. The coastal strand community at Morro Bay State Park, California. Bulletin of the Torrey Botanical Club 99:163-171.

Willis CK, Cowling RM, Lombard AT. 1996. Patterns of endemism in the limestone flora of South African lowland fynbos. Biodiversity and Conservation 5:55-73. DOI: 10.1007/BF00056292.

Wilson JB, Sykes MT. 1999. Is zonation on coastal sand dunes determined primarily by sand burial or by salt spray? A test in New Zealand dunes. Ecology Letters 2:233-236. DOI: 10.1046/j.1461-0248.1999.00084.x.

Wolfe AD. 2013. Hyobanche thinophila (Orobanchaceae), a new species from the Western Cape of South Africa. Phytotaxa 85:56-60. DOI: 10.11646/phytotaxa.85.2.3.

Zemunik G, Turner BL, Lambers H, Laliberté E. 2016. Increasing plant species diversity and extreme species turnover accompany declining soil fertility along a long-term chronosequence in a biodiversity hotspot. Journal of Ecology 104:792-805. DOI: 10.1111/1365-2745.12546.

Zietsman MM, Bredenkamp GJ. 2006. Dune vegetation and coastal thicket plant communities in threatened limestone fynbos of Andrew's Field and Tsaba-Tsaba Nature Reserve, Struisbaai, Western Cape. Koedoe 49:33-47.

Zietsman MM, Bredenkamp GJ. 2007. Threatened limestone fynbos plant communities of 
1843 Andrew's Field and Tsaba-Tsaba Nature Reserve, Western Cape. Bothalia 37:89-102. 


\section{Figure 1}

Distribution of calcareous substrata (coastal dunes and calcarenites) along the southwestern, southern and southeastern coasts of South Africa with which the coastal flora of the Cape Floristic Region (CFR) is associated.

Dunes occur along the entire CFR coast, while significant calcarenite outcrops are restricted to areas along the west coast (Saldanha Peninsula), south coast (Agulhas Plain) and southeast coast (Algoa Bay). Note that the extent of calcareous substrata is slightly exaggerated for visibility (adapted from South African Council for Geoscience 1:250,000 geological database). CFR centres are after Manning \& Goldblatt (2012a): NW, Northwest; SW, Southwest; KM, Karoo Mountain; LB, Langeberg; SE, Southeastern; SE-ext., extension of the Southeastern centre (cf. Colville et al., 2014; cf. Bradshaw, Colville $\&$ Linder, 2015). The approximate shoreline during the Last Glacial Maximum (LGM) is taken as the $130 \mathrm{~m}$ isobath and indicates the extent of the Palaeo-Agulhas Plain (Marean, Cowling \& Franklin, 2020) and analogous offshore land areas exposed at lower sea levels around $26.5 \mathrm{ka}$. 


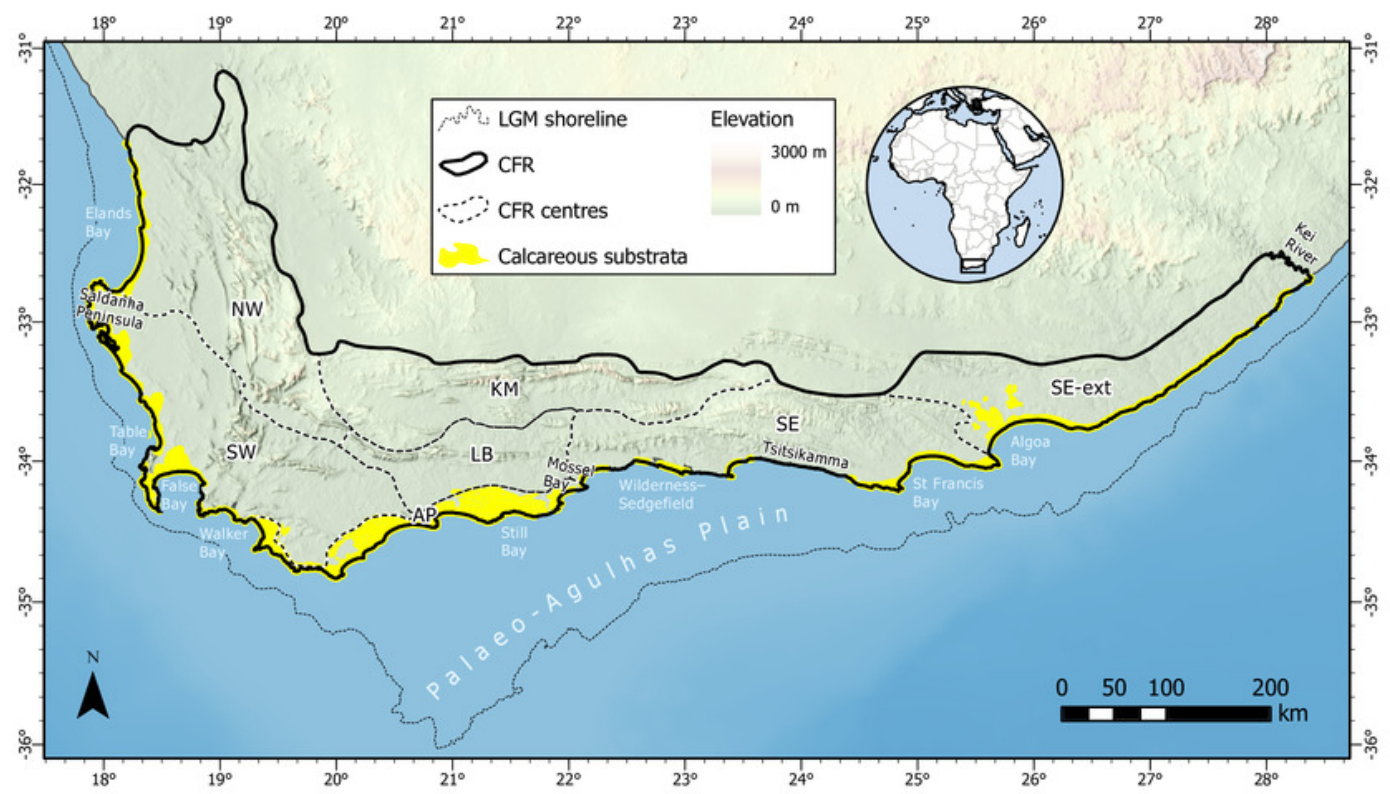




\section{Figure 2}

Dominant vegetation formations on coastal calcareous substrata of the Cape Floristic Region.

(A) Dune fynbos-thicket mosaic near Walker Bay, with the fynbos component dominant here.

(B) Dune fynbos-thicket mosaic near Algoa Bay, with the thicket component dominant here.

(C, D) Limestone fynbos on calcarenites near Walker Bay. (E) Strandveld, occurring on coastal dunes and calcarenites along the semi-arid west coast, near False Bay. (F) Grassyshrubland-thicket mosaic occurring on calcarenites inland of Algoa Bay. Photographs by B. Adriaan Grobler (A-D, F) and Richard M. Cowling (E). 


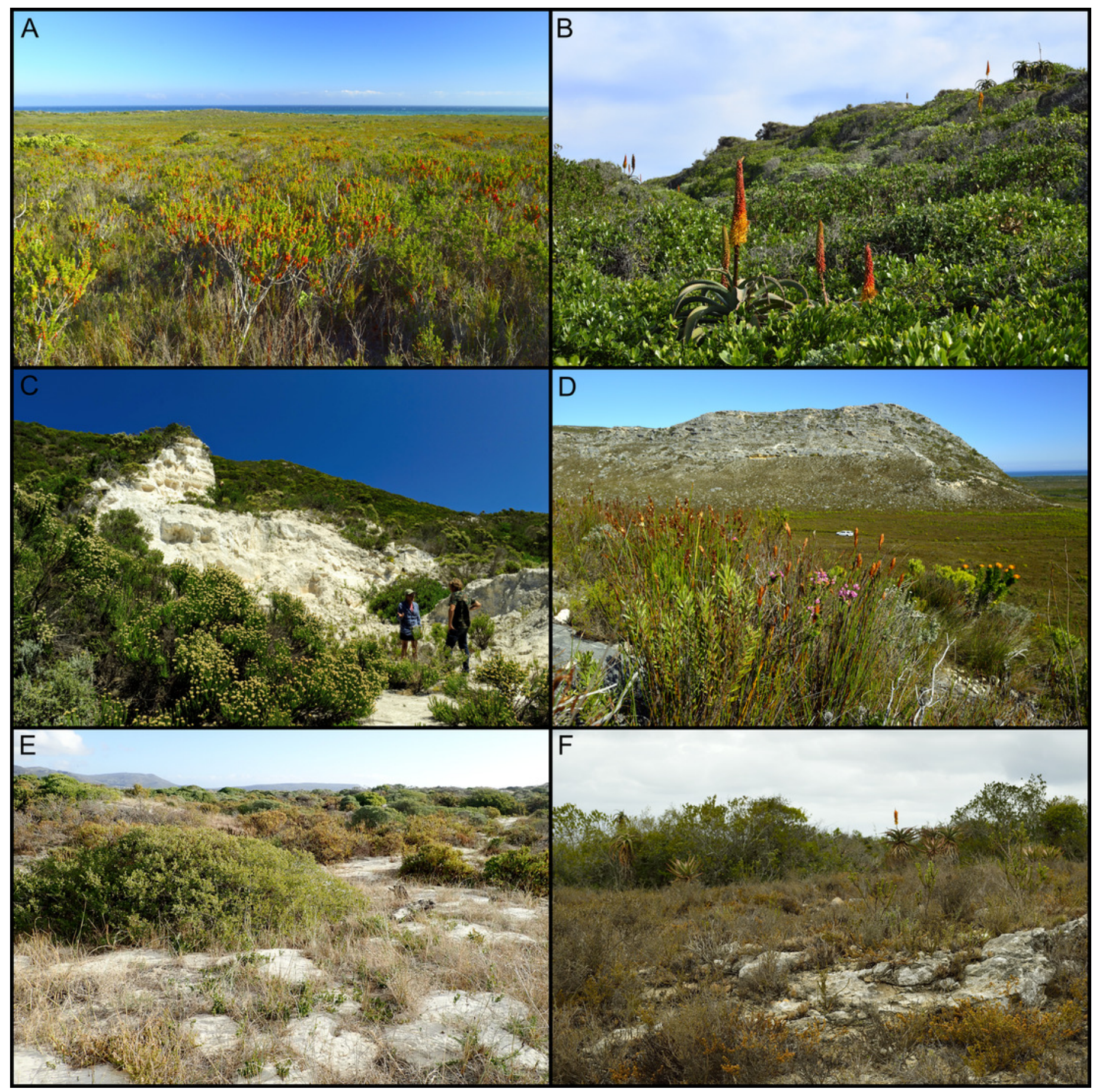


Figure 3

Treemap of the coastal flora of the Cape Floristic Region.

Depicted are the relative number of species per genus per family. The total flora comprises 1,365 species. Note that colours only aid to differentiate different plant families. 


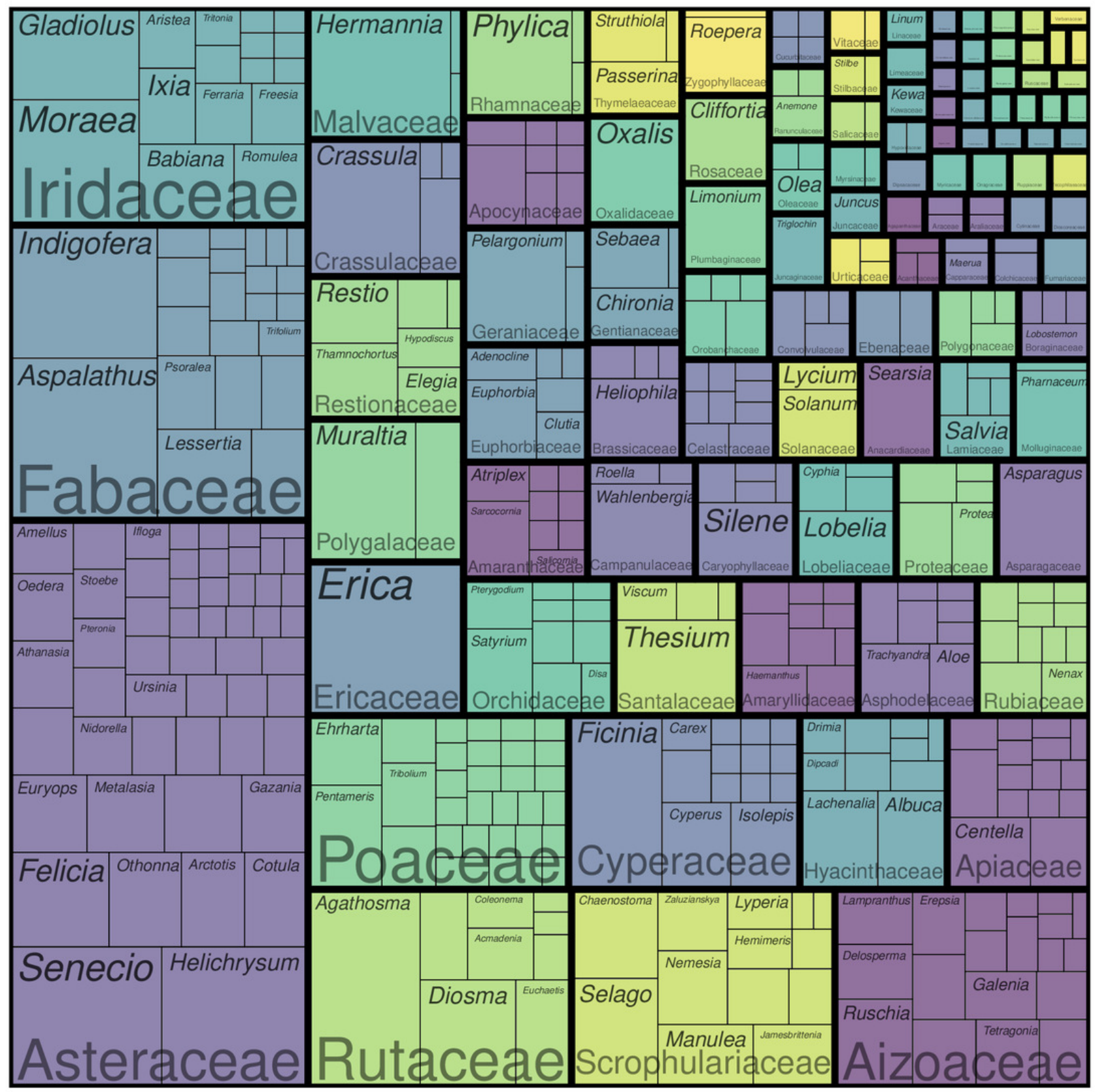




\section{Figure 4}

Biological traits of species in the coastal flora of the Cape Floristic Region (CFR), comprising 1,365 species.

(A) Proportion of species exhibiting different herbaceous growth forms (667 spp. total). (B) Proportion of species exhibiting different woody growth forms (698 spp. total). (C) Proportion of woody species exhibiting different post-fire regeneration strategies (698 spp. total). (D) Treemap of succulence in the coastal flora, showing proportion of non-succulent (white, NS) and succulent (grey) species, and proportion of herbaceous (H) and woody (W) succulent species. 
A

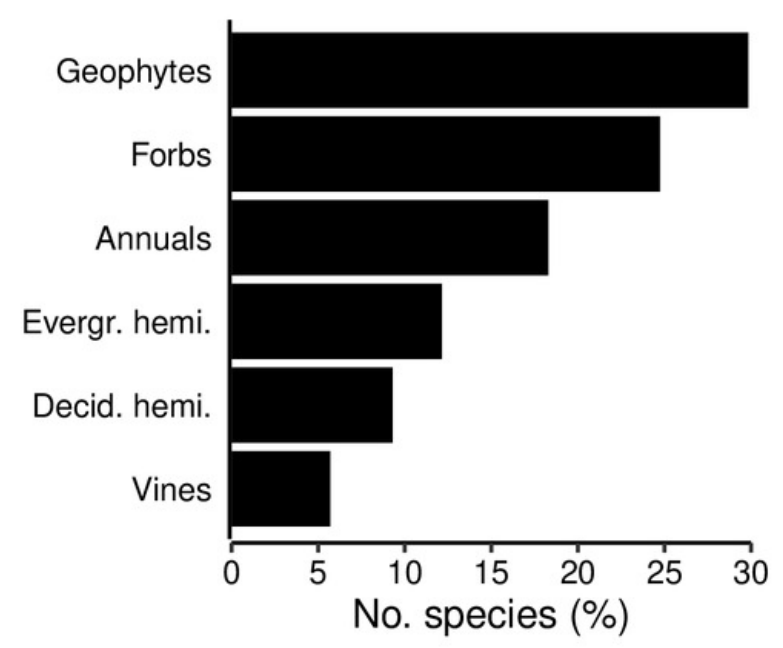

C

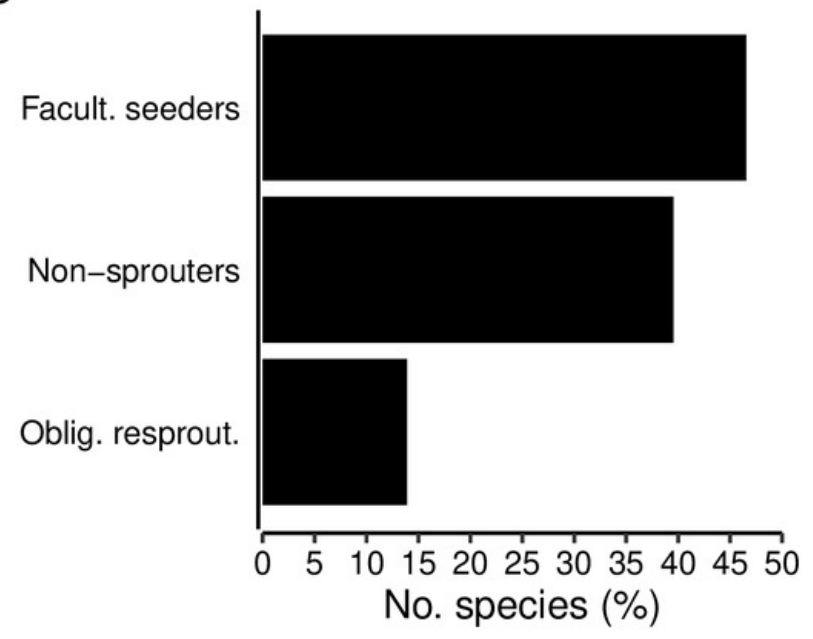

B

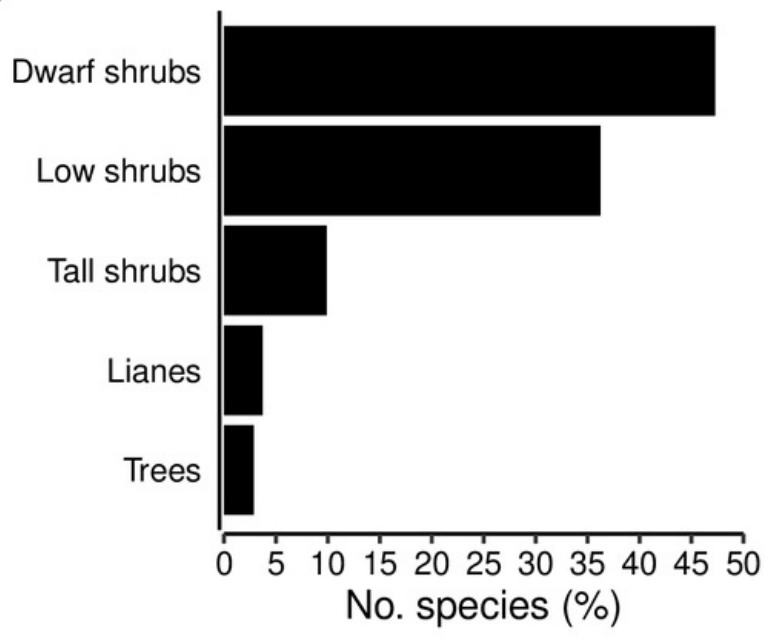

D

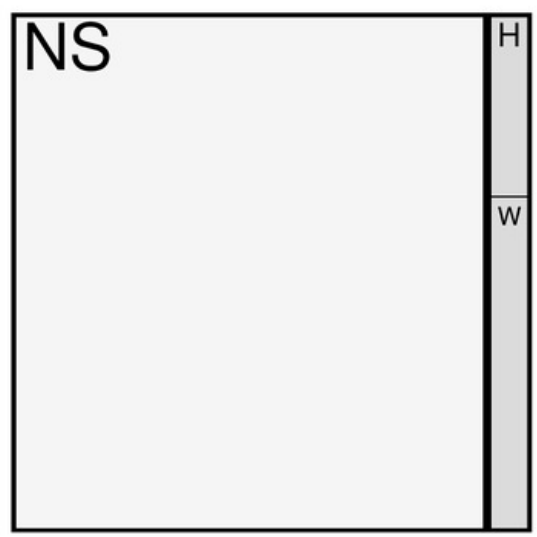




\section{Figure 5}

Geographical traits of species in the coastal flora of the Cape Floristic Region (CFR), comprising 1,365 species.

(A) Biome association, showing the proportion of species associated with each biome occurring on coastal forelands of the CFR. (B) Generic biogeography, showing the proportion of species whose genera are associated with different phytogeographic regions: GC, Greater Cape; SA, Southern Africa; Cosmo., Cosmopolitan; Pantr., Pantropical; Afrotemp., Afrotemperate; Pantemp., Pantemperate; Afrotrop., Afrotropical. (C) Treemap of regional endemism, showing the proportion of GCFR-endemic (white) and non-endemic species (grey), as well as proportion of species endemic to hierarchical phytogeographic units in the Greater Cape Floristic Region (GCFR). CFR centres are: AP, Agulhas Plain; SE, Southeastern; SW, Southwestern. Note that proportions of species in GCFR units are cumulative (i.e., total CFR endemics $=$ CFR centres + CFR, total GCFR endemics $=$ CFR centres + CFR + GCFR). 
A

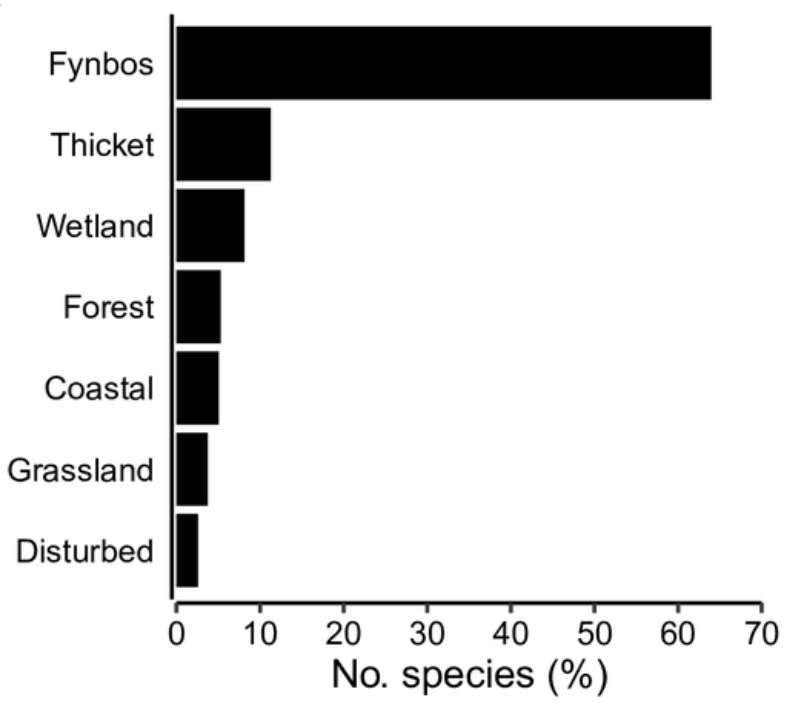

C

\begin{tabular}{|l|l|}
\hline GCFR & \\
\hline AP & SE \\
& SW \\
& \\
\hline CFR & \\
& \\
& \\
\end{tabular}

B

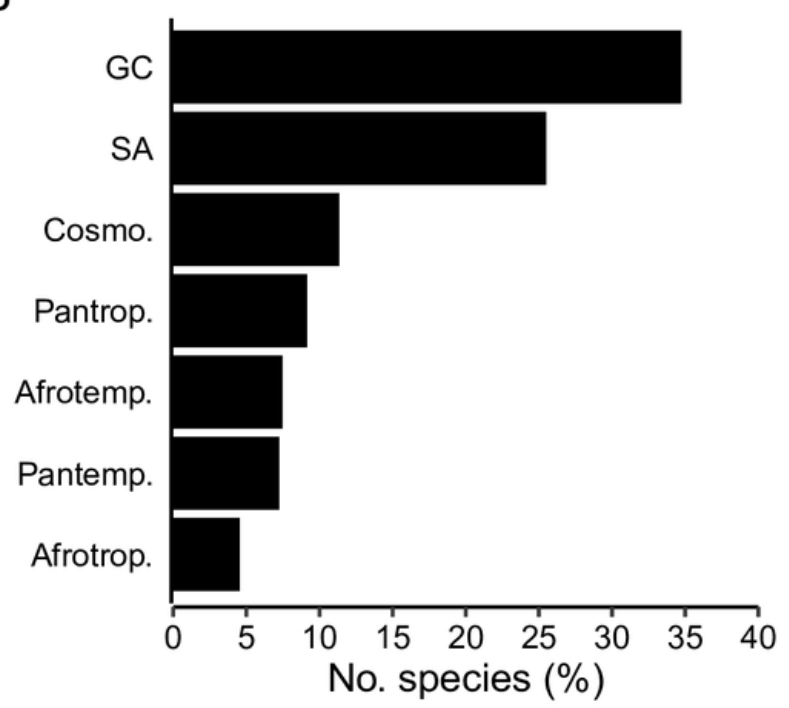




\section{Figure 6}

Edaphic traits of species in the coastal flora of the Cape Floristic Region (CFR), comprising 1,365 species.

(A) Edaphic distribution of species in the CFR coastal flora. Widespread species occur on calcareous as well as other substrata in the CFR. Species restricted to calcareous substrata are: $C E$, calcarenite endemics; $D E$, dune endemics; $C U$, calcicole ubiquists occurring on both calcarenites and dunes. (B) Distribution of edaphically widespread species that exhibit some edaphic association (i.e., excluding species that occur on all substrate types) on four major substrata of the CFR (436 spp. total). Substrata are: CC, alkaline moderately fertile sand (coastal dunes and calcarenites); CS, deep acidic low-fertility sand; SS, shallow acidic lowfertility sand; $\mathrm{SH}$, deep neutral highly fertile loam. The size of solid circles is scaled relative to the number of species occurring on each substrate (species numbers shown under substrate codes), while the width of lines connecting substrata is scaled relative to the number of species shared between those substrata (species numbers shown in stippled circles along lines). See Table 1 for substrate characteristics. 
A

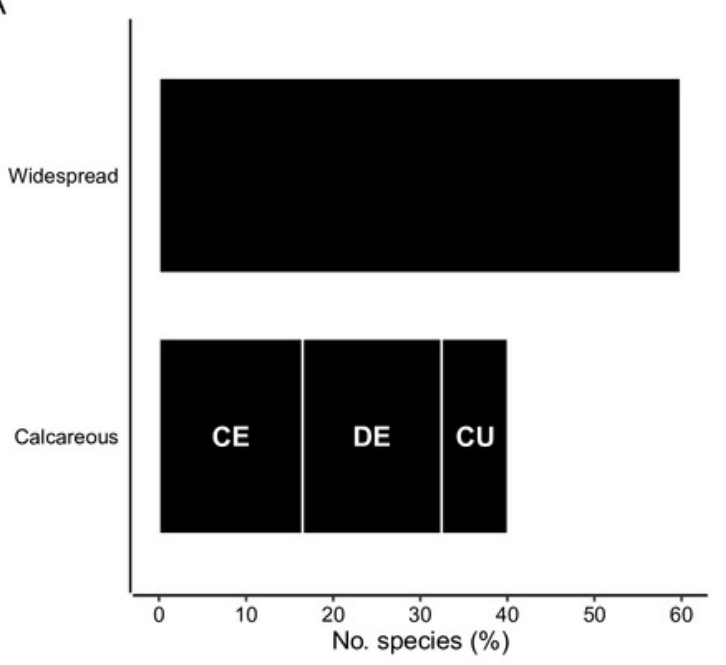

B

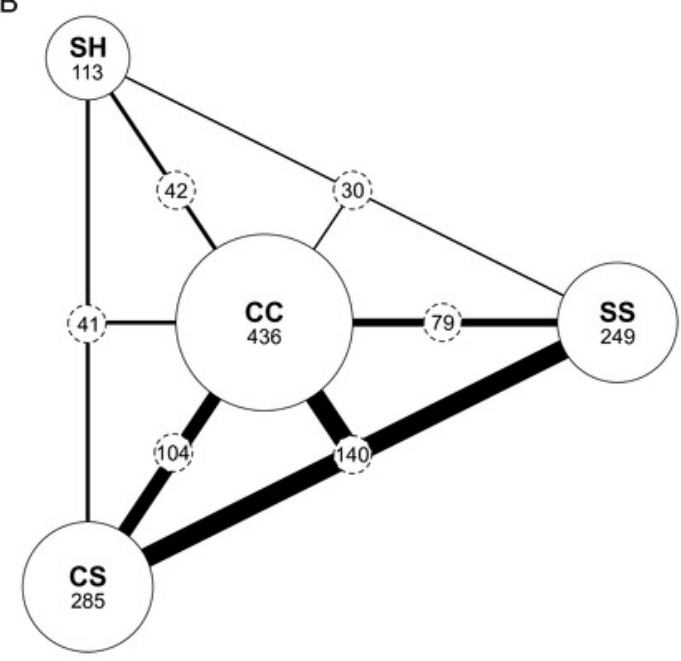




\section{Figure 7}

Treemaps of the calcicole flora of the Cape Floristic Region.

Depicted are the relative number of species per genus per family. (A) The total calcicole flora (species endemic to calcareous substrata; 548 spp.). (B) The calcicole-ubiquist flora (calcicolous species occurring on both dunes and calcarenites; 104 spp.). (C) The calcareniteendemic flora (218 spp.). (D) The dune-endemic flora (226 spp.). Note that B-D are subsets of $A$. Note that colours only aid to differentiate different plant families. 
A

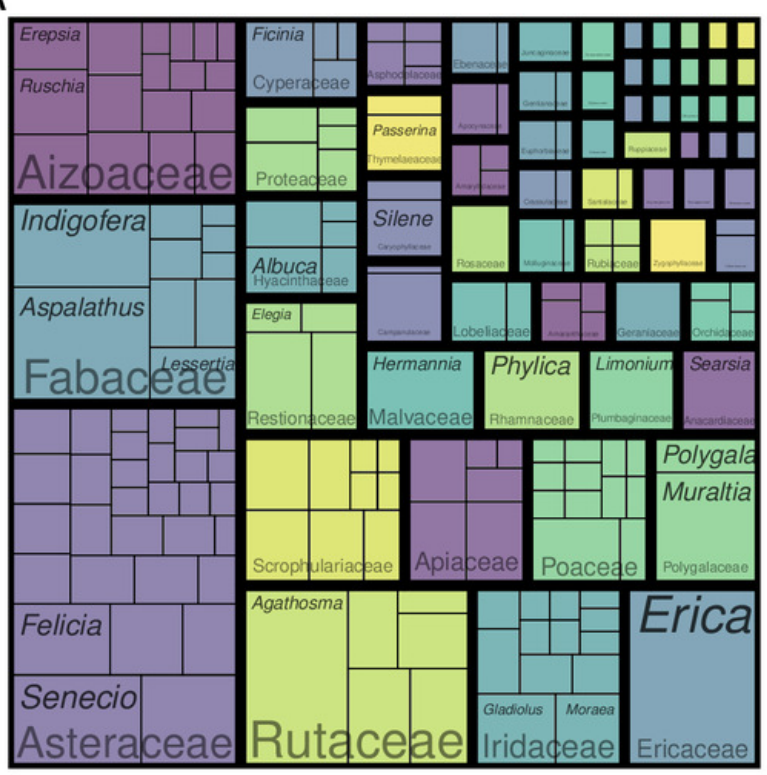

C

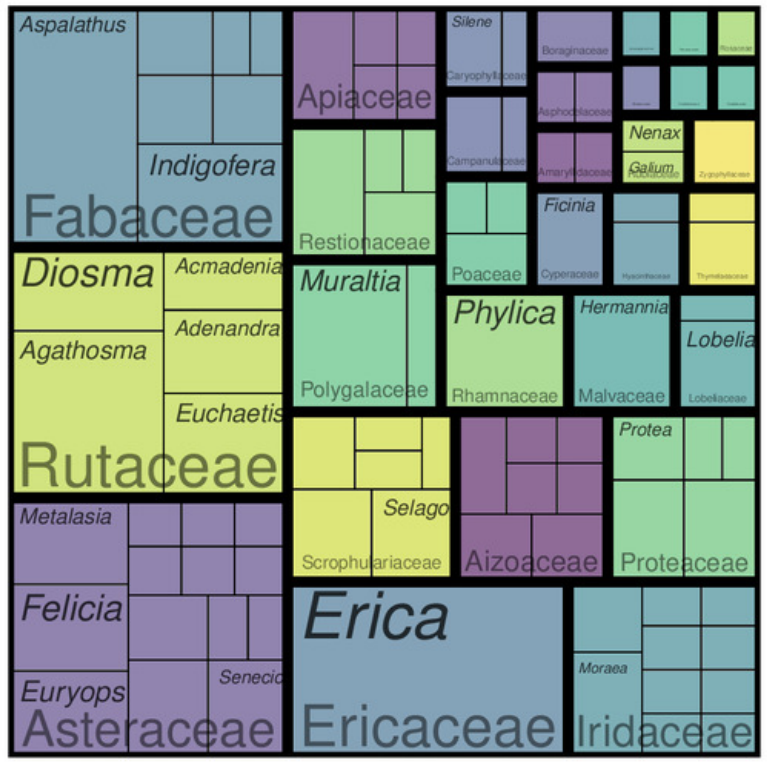

B

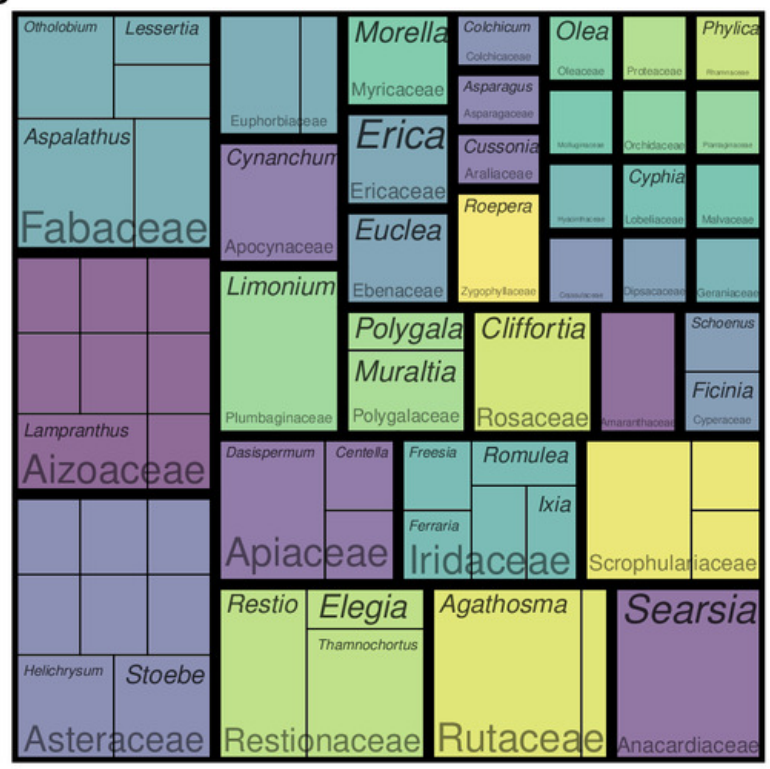

D

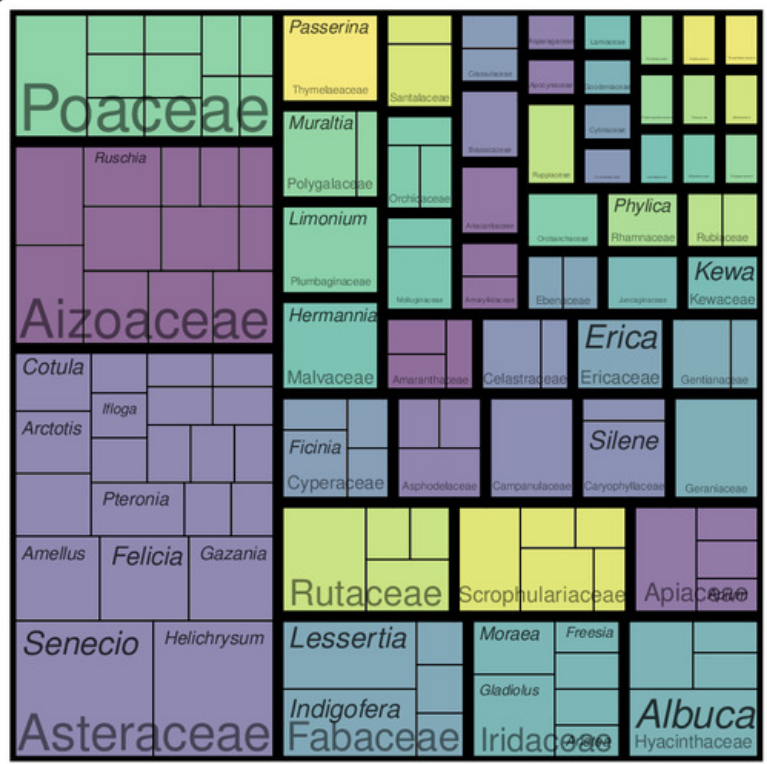




\section{Figure 8}

Examples of calcarenite-endemic species from the coastal flora of the Cape Floristic Region.

(A) Brachysiphon mundii of the Penaeaceae. (B) Protea obtusifolia of the Proteaceae. (C) Leucadendron muirii of the Proteaceae. (D) Mimetes saxatilis of the Proteaceae. (E) Adenandra obtusata of the Rutaceae. (F) Diosma guthriei of the Rutaceae. (G) Erica occulta of the Ericaceae. (H) Metalasia calcicola of the Asteraceae. (I) Achyranthemum recurvatum of the Asteraceae. Most calcarenite endemics belong to Cape lineages. Photographs by Nick Helme (A), Ross C. Turner (G) and B. Adriaan Grobler (B-F, H, I). 


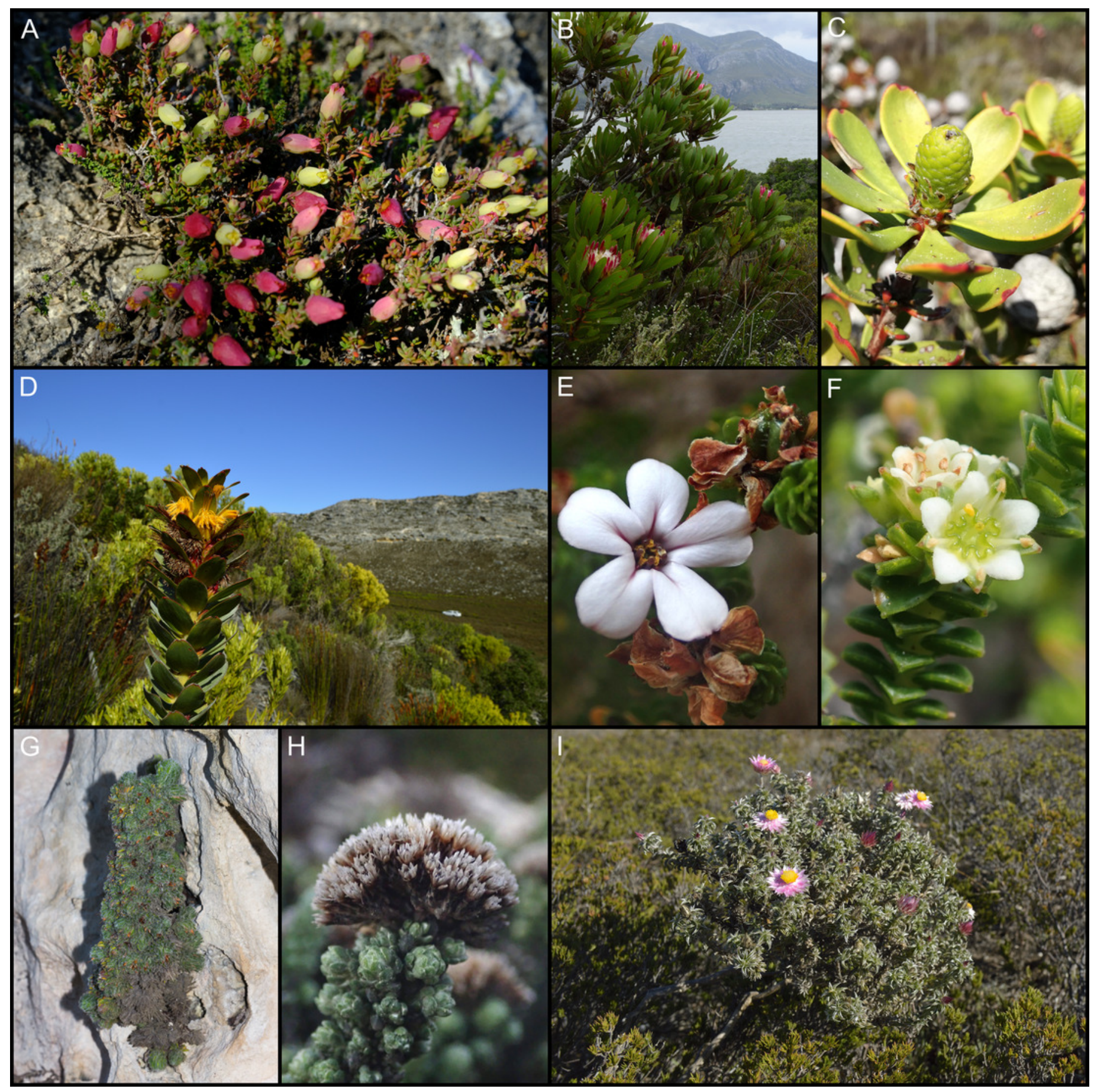




\section{Figure 9}

Examples of dune-endemic species from the coastal flora of the Cape Floristic Region.

(A) Erica chloroloma of the Ericaceae. (B) Agathosma stenopetala of the Rutaceae. (C)

Coleonema pulchellum of the Rutaceae. (D) Muraltia satureioides of the Polygalaceae. (E)

Othonna rufibarbis of the Asteraceae. (F) Otholobium sp. nov. 'algoensis' of the Fabaceae.

(G) Aspalathus cliffortiifolia of the Fabaceae. (H) Hyobanche robusta of the Orobanchaceae.

(I) Brunsvigia litoralis of the Amaryllidaceae. Satyrium princeps of the Orchidaceae. (K)

Pelargonium suburbanum subsp. suburbanum of the Geraniaceae. Most dune endemics belong to Cape (A-G) or Southern African (H-K) lineages. Photographs by B. Adriaan Grobler. 


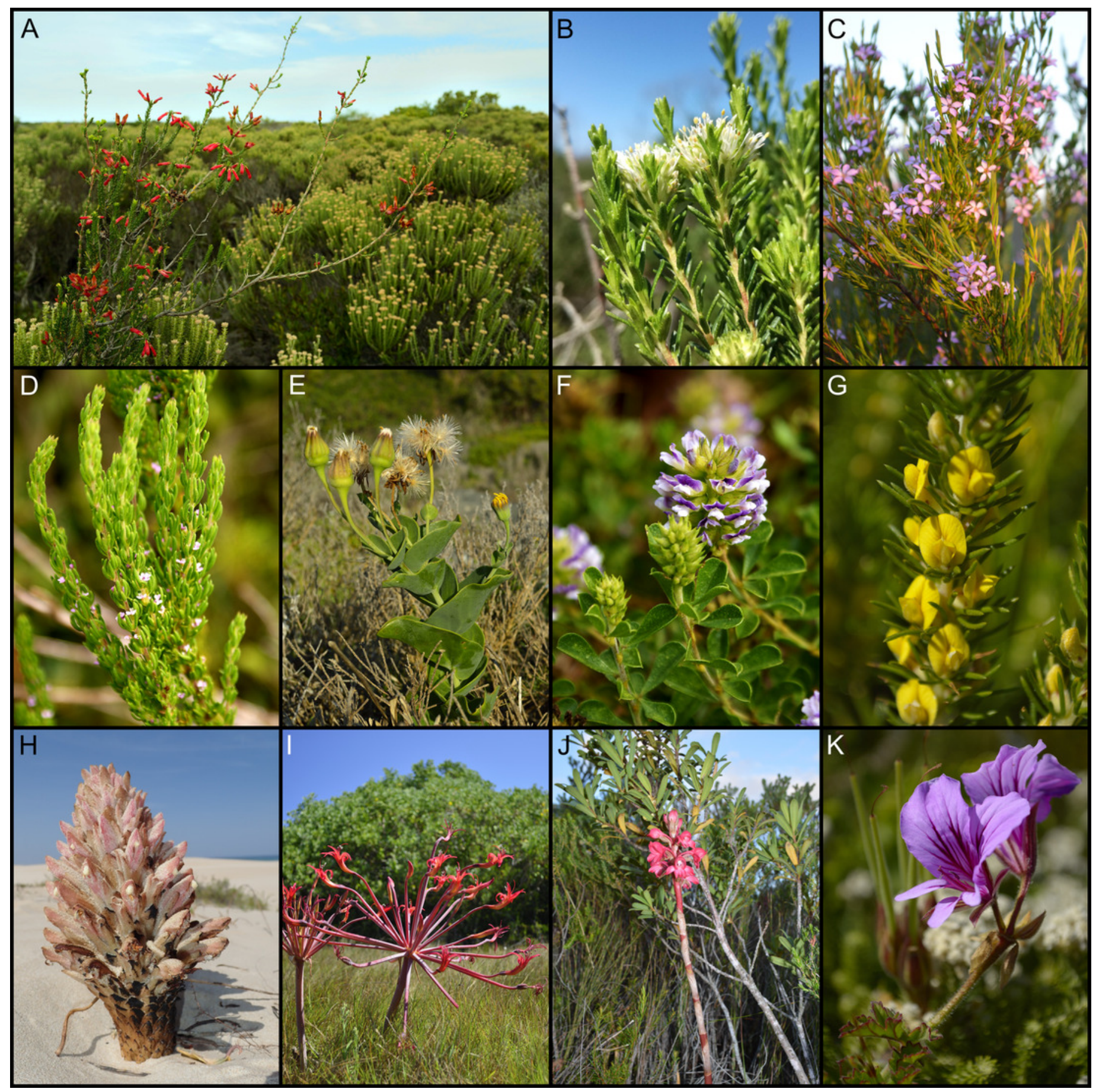




\section{Figure 10}

Growth on different coastal calcareous substrata of the dune-endemic Erica glumiflora (Ericaceae) from the southeastern Cape Floristic Region.

(A) Typical plant stature, reaching heights of $0.6-1.0 \mathrm{~m}$, in deep dune sand. (B) Atypical stunted growth on calcarenite, with plants rarely growing taller than $0.1 \mathrm{~m}$. Photographs by $\mathrm{B}$. Adriaan Grobler.

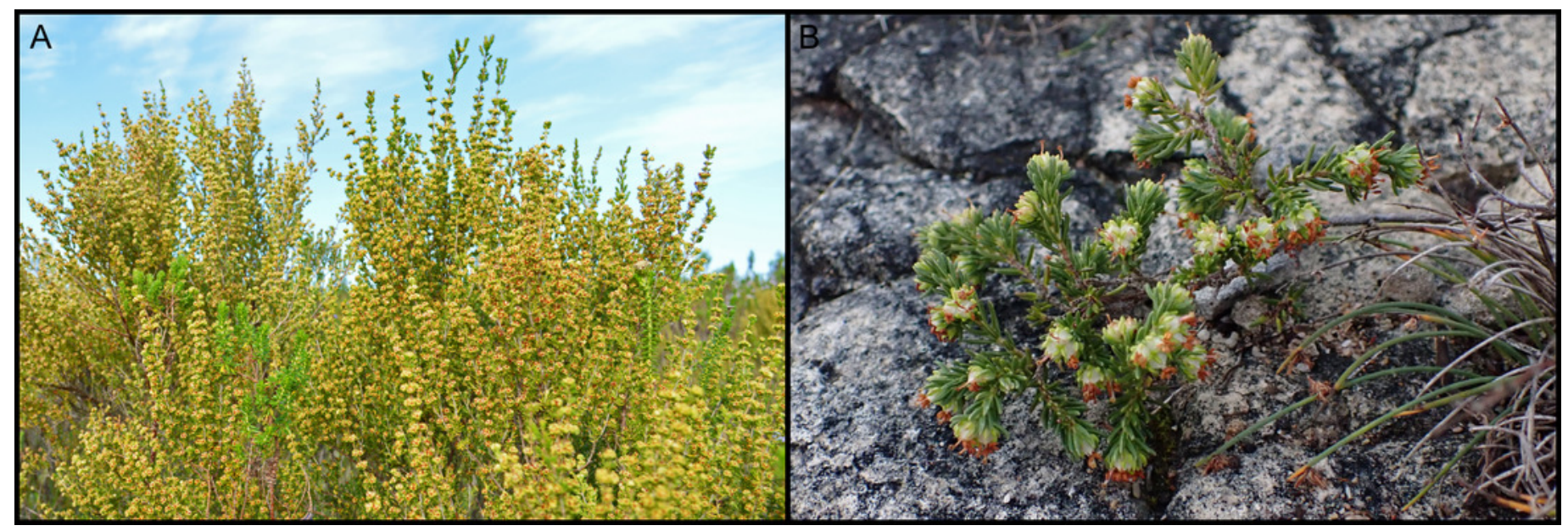




\section{Figure 11}

Widespread trees of typically arborescent tropical genera and their calcicolous shrub descendants in the coastal flora of the Cape Floristic Region.

(A) Rapanea melanophloes is closely related to (B) the Cape dune endemic Rapanea gilliana. Maytenus undata is the sister species of (D) the dune endemic Maytenus procumbens. (E) Olea capensis, which most frequently grows as a forest tree, is sister to the Cape-endemic calcicole, Olea exasperata. Note that of the widespread species (A, C, D), only Olea capensis occurs in dunes. Photographs by B. Adriaan Grobler (A, B, D, F), Graeme Pienaar (C) and Tony Rebelo (E). 


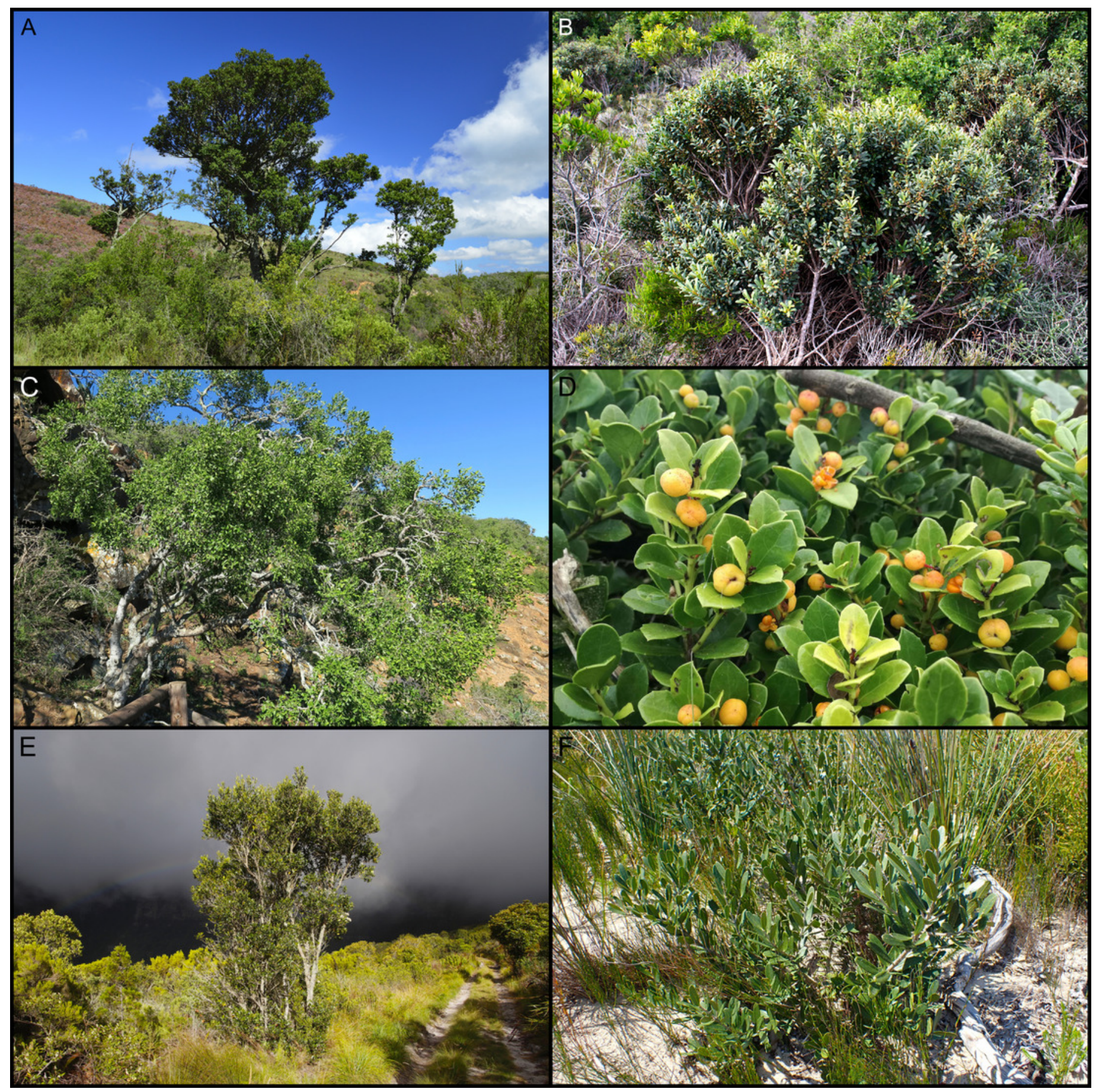




\section{Table $\mathbf{1}$ (on next page)}

Characteristics of broad soil groups occurring on coastal lowlands of the Cape Floristic Region, corresponding to edaphic categories to which species in the coastal flora were assigned.

Note that these categories were not mutually exclusive (i.e., certain species occur on multiple soil types). 
1 Table 1: Characteristics of broad soil groups occurring on coastal lowlands of the Cape Floristic Region, 2 corresponding to edaphic categories to which species in the coastal flora were assigned. Note that these

3 categories were not mutually exclusive.

\begin{tabular}{|l|l|l|l|l|l|l|}
\hline Associated geology & Texture & Fertility & $\mathbf{p H}$ & Depth * & Soil description & Vegetation \\
\hline $\begin{array}{l}\text { Unconsolidated } \\
\text { coastal dunes }\end{array}$ & Sand & Moderate & Alkaline & Deep & $\begin{array}{l}\text { Deep alkaline } \\
\text { moderately } \\
\text { fertile sand }\end{array}$ & $\begin{array}{l}\text { Dune fynbos- } \\
\text { thicket mosaic }\end{array}$ \\
\hline $\begin{array}{l}\text { Calcarenites and } \\
\text { calcretes }\end{array}$ & Sand & Moderate & Alkaline & Shallow & $\begin{array}{l}\text { Shallow alkaline } \\
\text { moderately } \\
\text { fertile sand }\end{array}$ & $\begin{array}{l}\text { Limestone } \\
\text { fynbos }\end{array}$ \\
\hline $\begin{array}{l}\text { Windblown cover } \\
\text { sands }\end{array}$ & Sand & Low & Acidic & Deep & $\begin{array}{l}\text { Deep acidic low- } \\
\text { fertility sand }\end{array}$ & Sand fynbos \\
\hline $\begin{array}{l}\text { Quartzitic } \\
\text { sandstones }\end{array}$ & Sand & Low & Acidic & Shallow & $\begin{array}{l}\text { Shallow acidic } \\
\text { low-fertility } \\
\text { sand }\end{array}$ & $\begin{array}{l}\text { Sandstone } \\
\text { fynbos }\end{array}$ \\
\hline $\begin{array}{l}\text { Shales, mudstones, } \\
\text { conglomerates }\end{array}$ & Loam & High & Neutral & Deep & $\begin{array}{l}\text { Deep neutral } \\
\text { highly fertile } \\
\text { loam }\end{array}$ & Renosterveld \\
\hline * Deep, $>0.3 \mathrm{~m}$; Shallow, $<0.3 \mathrm{~m}$ & & & & & \\
\hline
\end{tabular}

4 